Przegląd Narodowościowy / Review of Nationalities • nr 7/2017 • World of Slavs / Świat Słowian

\title{
Slavic idea in political thought of underground Poland during World War II
}

Idea słowiańska w myśli politycznej Polski podziemnej w czasie II wojny światowej

Keywords: the Slavic idea, the Slavic nations, the Polish-Soviet relations

During the Second World War, the Polish government put forward a plan for a new political order in Central Europe. Its integration was to be based on the PolishCzechoslovak federation. Apart from the federal idea among the groups in the occupied country as well as in the emigration, imperial and Slavic ideas spread as ideological foundations of Central European order. The Slavic idea was universal enough to exist spontaneously and as part of the federal and imperial ideas. Within them, the Slav countries were to form the basis for the regional integration of states between imperialist Germany and the USSR and the Baltic, Black and Adriatic Sea. Promoting Slavic ideas in the country and emigration became problematic at the time of the German aggression on the USSR. Soviet propaganda used it for opportunistic purposes to intensify armed struggle in Nazi-occupied Slav nations and long-range ones for their post-war dependency. The research problems stemming
Słowa kluczowe: idea słowiańska, narody słowiańskie, stosunki polsko-radzieckie

W czasie II wojny światowej polski rząd wysunął plan nowego ładu politycznego w Europie Środkowej. Jej integracja miała opierać się na federacji polsko-czechosłowackiej. Oprócz idei federacyjnej wśród ugrupowań w okupowanym kraju, jak i na emigracji, szerzyły się idee imperialna i słowiańska jako ideologiczne podstawy porządku środkowoeuropejskiego. Idea słowiańska była na tyle uniwersalna, że występowała samoistnie oraz jako część idei federacyjnej i imperialnej. $\mathrm{W}$ ich ramach państwa słowiańskie miały stanowić podstawę integracji regionalnej państw położonych między imperialistycznymi Niemcami i ZSRR oraz Morzem Bałtyckim, Czarnym i Adriatyckim. Propagowanie idei słowiańskiej w kraju i na emigracji stało się problematyczne w momencie agresji niemieckiej na ZSRR. Radziecka propaganda wykorzystywała ją w celach koniunkturalnych do wzmożenia walki zbrojnej w okupowanych przez Niemcy narodach słowiańskich oraz dale-

* Correspondence address: Zakład Historii Nowożytnej, Akademia Sztuki Wojennej, al. gen. A. Chruściela "Montera” 103, 00-910 Warszawa-Rembertów, e-mail: d.miszewski@op.pl. 
from it are the question of the attitude of Polish authorities in the country and emigration to Soviet Slavic propaganda as well as to Polish groups spreading the Slavic idea. On the other hand, in relation to the occupied country, the issues of the Polish underground groupings in general, the Slavic idea as such, the attitude towards the USSR and its propaganda, the scope and forms of integration of the Slavic area after the Second World War were discussed as the most important.

In December 1939, Prime Minister Władysław Sikorski announced a new political organization in Central Europe. It would be based on a "solidarity of Slavic states" between the Baltic, the Black Sea and the Adriatic, to stop the aggression of the neighboring powers ${ }^{1}$. He was in favor of the integration of Europe made up of regional federations ${ }^{2}$. He intended to create with Czechoslovakia the Central European Federation ${ }^{3}$. The emigre governments of both countries signed a post-war agree-

1 Odezwa Rzadu z dnia 18 XII 1939 r. do ogółu społeczeństwa w kraju, [in:] Rzeczpospolita Polska czasu wojny. Dziennik Ustaw i Monitor Polski 19391945, edit. A.K. Kunert, Warszawa 1999, Monitor Polski, “Angers” 19.12.1939, year 22, No. 277-284 (Sikorski later did not use the Slavonic term in the official documents for the Central European union).

2 E. Ponczek, Idea federacji europejskiej $w$ polskiej myśli politycznej (1939-1945), [in:] Proces integracji Polski z Unia Europejska, edit. P. Dobrowolski, M. Stolarczyk, Katowice 2001, pp. 211-212; J.R. Sielezin, Idea federacji polsko-czechosłowackiej jako element gry politycznej w latach 1939-1943, [in:] Europa Środkowo-Wschodnia w polskiej myśli politycznej, edit. M. Dymarski, J. Juchnowski, Wrocław 2004, pp. 137-138.

3 E. Raczyński, W sojuszniczym Londynie. Dziennik ambasadora Edwarda Raczyńskiego 19391945, Londyn 1960, p. 60; E. Duraczyński, Rząd polski na uchodźstwie 1939-1945, Warszawa 1993, pp. 86-87. kosiężnych do powojennego ich uzależnienia. Problemami badawczymi stąd wynikającymi były zagadnienia stosunku polskich władz w kraju i na emigracji wobec radzieckiej propagandy słowiańskiej, jak i do szerzących ideę słowiańską polskich ugrupowań. Natomiast w odniesieniu do okupowanego kraju wysuwały się na plan pierwszy zagadnienia w ogóle ustosunkowania się polskich ugrupowań podziemnych do idei słowiańskiej jako takiej, stosunku do ZSRR i jego propagandy, zasięgu i form integracji obszaru słowiańskiego po II wojnie światowej.

W grudniowej odezwie do kraju z 1939 r. premier generał Władysław Sikorski zapowiedział nową organizację polityczną Europy Środkowej. Jej podstawą byłby „solidarny zespół państw słowiańskich" między Bałtykiem, Morzem Czarnym i Adriatykiem, aby powstrzymać agresję sąsiednich mocarstw ${ }^{1}$. Był za integracją Europy złożoną z federacji regionalnych ${ }^{2}$. Federację środkowoeuropejską zamierzał utworzyć z Czechosłowacjąa ${ }^{3}$ Emigracyjne

1 Odezwa Rzadu z dnia 18 XII 1939 r. do ogółu społeczeństwa w kraju, [w:] Rzeczpospolita Polska czasu wojny. Dziennik Ustaw i Monitor Polski 1939-1945, red. A.K. Kunert, Warszawa 1999; Monitor Polski, „Angers” 19.12.1939, rok 22, nr 277-284. (Później Sikorski nie używał już w oficjalnych dokumentach określenia słowiański na związek środkowoeuropejski).

2 E. Ponczek, Idea federacji europejskiej $w$ polskiej myśli politycznej (1939-1945), [w:] Proces integracji Polski z Unią Europejską, red. P. Dobrowolski, M. Stolarczyk, Katowice 2001, s. 211-212; J.R. Sielezin, Idea federacji polsko-czechosłowackiej jako element gry politycznej w latach 1939-1943, [w:] Europa Środkowo-Wschodnia w polskiej myśli politycznej, red. M. Dymarski, J. Juchnowski, Wrocław 2004, s. $137-138$

3 E. Raczyński, W sojuszniczym Londynie. Dziennik ambasadora Edwarda Raczyńskiego 1939- 
ment in 1940-1942, open to other Central European countries ${ }^{4}$. Yugoslavia and Greece did the same in 1942. W. Sikorski's plans gained British support ${ }^{5}$. The peace order combined with the concepts of political blocs, unions, confederations, or federations as an alternative to the spheres of influence and dominance of the superpowers in Europe and the world ${ }^{6}$. Poland declared relations with the USSR on the basis of sovereignty, territorial integrity and non-interference in internal affairs ${ }^{7}$. President Edvard Beneš insisted on obtaining USSR approval for their project ${ }^{8}$.

${ }^{4}$ Zakład Narodowy im. Ossolińskich (ZNO), Papiery Kazimierza Sosnkowskiego (PKS), sygn. 16536/II, Protokól posiedzenia Rady Ministrów z 31 X 1940, pp. 19-20; Za wasza wolność i nasza, "Robotnik Polski w Wielkiej Brytanii" (RPWB), 12.01.1941, No. 1, p. 2; J. Němeček, Czechosłowacko-polskie koncepcje federacyjne $w$ okresie drugiej wojny światowej, [in:] Europa unii i federacji. Idea jedności narodów i państw od średniowiecza do czasów wspótczesnych, edit. K. Ślusarek, Kraków 2004, pp. 344-349; M.K. Kamiński, E. Beneš kontra generał W. Sikorski. Polityka władz czechosłowackich na emigracji wobec rządu polskiego na uchodźstwie 1939-1943, Warszawa 2005 , pp. 48-53.

${ }^{5}$ R. Żurawski vel Grajewski, Foreign Office wobec stosunków polsko-czechosłowackich (listopad 1940-sierpień 1942), [in:] Między przymusowa przyjaźnią a prawdziwa solidarnościa Czesi - Polacy - Stowacy 1938/39-1945-1989, part 1, edit. P. Blažek, P. Jaworski, Ł. Kamiński, Warszawa 2007, pp. 110-111.

${ }^{6}$ E. Ponczek, Polska myśl o pokoju w latach drugiej wojny światowej (1939-1945), Łódź 1999, p. 127; B. Pasierb, Marian Seyda i resort planowania politycznego na obczyźnie, 1939-1944, [in:] Polska - Kresy Polacy. Studia historyczne, edit. S. Ciesielski, T. Kulak, K. Matwijowski, "AUW. Historia”, vol. 116, No 1636, Wrocław 1994, pp. 259-263.

7 ZNO, sygn. 294073, Przemówienie radiowe ministra Stańczyka. Polska i Rosja, "Dziennik Polski” (DP), 10.09.1941, No. 359, p. 2.

8 J. Němeček, Edvard Beneš i Władysław Sikorski: spojrzenie ze strony czeskiej, "Dzieje Najnowsze" 2000, 3 (32), pp. 119-134; R. Žáček, Projekt československo-polské konfederace v letech 1939-1943, Opava 2001, p. 41. rządy obu państw zawarły w latach 19401942 umowy o powojennym związku, otwartym na inne kraje Europy Środkowej ${ }^{4}$. Podobnie uczyniły w 1942 r. Jugosławia i Grecja. Plany W. Sikorskiego zyskały poparcie Wielkiej Brytanii ${ }^{5}$. Ład pokojowy łączył z koncepcjami bloków politycznych, unii, konfederacji czy federacji jako alternatywą dla stref wpływów i dominacji mocarstw w Europie i na świecie ${ }^{6}$. Polska deklarowała stosunki z ZSRR na zasadach suwerenności, integralności terytorialnej i nieingerencji w sprawy wewnętrzne ${ }^{7}$. Prezydent Edvard Beneš nalegał na uzyskanie zgody ZSRR dla ich projektu ${ }^{8}$.

1945, Londyn 1960, s. 60; E. Duraczyński, Rząd polski na uchodźstwie 1939-1945, Warszawa 1993, s. 86-87.

${ }^{4}$ Zakład Narodowy im. Ossolińskich (ZNO), Papiery Kazimierza Sosnkowskiego (PKS), sygn. 16536/II, Protokót posiedzenia Rady Ministrów z 31 X 1940, s. 19-20; Za wasza wolność i nasza, „Robotnik Polski w Wielkiej Brytanii” (RPWB), 12.01.1941, nr 1, s. 2; J. Němeček, Czechosłowacko-polskie koncepcje federacyjne w okresie drugiej wojny światowej, [w:] Europa unii i federacji. Idea jedności narodów i państw od średniowiecza do czasów wspótczesnych, red. K. Ślusarek, Kraków 2004, s. 344349; M.K. Kamiński, E. Beneš kontra generał W. Sikorski. Polityka władz czechosłowackich na emigracji wobec rzadu polskiego na uchodźstwie 1939-1943, Warszawa 2005, s. 48-53.

${ }^{5}$ R. Żurawski vel Grajewski, Foreign Office wobec stosunków polsko-czechosłowackich (listopad 1940-sierpień 1942), [w:] Między przymusowa przyjaźniq a prawdziwa solidarnościa Czesi - Polacy Słowacy 1938/39-1945-1989, cz. 1, red. P. Blažek, P. Jaworski, Ł. Kamiński, Warszawa 2007, s. 110-111.

${ }^{6}$ E. Ponczek, Polska myśl o pokoju w latach drugiej wojny światowej (1939-1945), Łódź 1999, s. 127; B. Pasierb, Marian Seyda i resort planowania politycznego na obczyźnie, 1939-1944, [w:] Polska - Kresy Polacy. Studia historyczne, red. S. Ciesielski, T. Kulak, K. Matwijowski, „AUW. Historia”, t. 116, nr 1636, Wrocław 1994, s. 259-263.

7 ZNO, sygn. 294073, Przemówienie radiowe ministra Stańczyka. Polska i Rosja, „Dziennik Polski” (DP), 10.09.1941, nr 359, s. 2.

${ }^{8}$ J. Němeček, Edvard Beneš $i$ Władysław Sikorski: spojrzenie ze strony czeskiej, „Dzieje Najnowsze” 
During the preparation of the PolishSoviet talks in London in 1941, Soviet Ambassador Ivan Majski informed the Foreign Minister, Anthony Eden, of the creation of a front for the Slav nations against Germany. In a conversation with A. Eden, Sikorski stated that the "red Pan-Slavism" was a competition for the Central European federation and the Balkan Union. They would be a barrier to German and Soviet imperialism, and the Slavic block "the bulwark or the extension of Russia". W. Sikorski based regional federations in Europe on the Western powers ${ }^{10}$. Declared an agreement with the USSR, but rejected the dependence, Slavophilia, communism and its territorial demands ${ }^{11}$. In December 1941, after the talks with the Soviet ambassador in Washington Maxim Litvinov, head of the Foreign Ministry, Edward Raczyński wrote that he opposed the Polish plans of the federation of Cen-

9 ZNO, PKS, sygn. 16528/II, Rozmowa gen. Sikorskiego z ministrem Edenem $w$ obecności J. Retingera, Londyn 4.07.1941, p. 100.

10 W pałacu św. Jakuba; Nieprzejednana walka do zwycięstwa (przemówienie Sikorskiego), DP, 14.06.1941, No. 284, pp. 2-3; Deklaracja polsko-sowiecka; W imię wolności, DP, 6.12.1941, No. 434, pp. 1, 3; Archiwum Akt Nowych, Delegatura Rządu na Kraj (DR), Departament Informacji i Prasy (DIP), sygn. 202/III-68/A, Konferencja w pałacu św. Jakuba, Radio Londyn 13.06.1941, p. 90; H. Batowski, Polska dyplomacja na obczyźnie 1939-1941, Kraków 1991, pp. 356-357.

11 ZNO, PKS, sygn. 16531/II, Sprawozdanie z podróży na Średni Wschód i do Rosji, No. 23/III/42, 13 I 1942, pp. 47-54; Notatka ze śniadania gen. Sikorskiego z premierem Churchillem na Downing Street 10, 11 III 1942, pp. 31-33; Depesza No. 226 Raczyńskiego do Ambasadora RP w Waszyngtonie, Londyn 12 IV 1942, p. 60; Instytut Polski i Muzeum im. gen. Sikorskiego w Londynie (IPMS), sygn. PRM67, Memorandum do rządu Wielkiej Brytanii, 27.03.1942, pp. $80-89$.
W okresie przygotowań do rozmów polsko-radzieckich w Londynie w $1941 \mathrm{r}$. radziecki ambasador Iwan Majski informował ministra spraw zagranicznych Anthony'ego Edena o tworzeniu frontu walki narodów słowiańskich wobec Niemiec. W rozmowie z A. Edenem W. Sikorski stwierdził, że „czerwony panslawizm” był konkurencją dla federacji środkowoeuropejskiej i unii bałkańskiej. Byłyby one zaporą dla niemieckiego i radzieckiego imperializmu, a blok słowiański „przedmurzem czy przybudówką Rosji”" Władysław Sikorski opierał federacje regionalne w Europie na zachodnich mocarstwach $^{10}$. Deklarował porozumienie się z ZSRR, ale odrzucał zależność, słowianofilstwo, komunizm i jego żądania terytorialne ${ }^{11}$. W grudniu 1941 r. po rozmowie $\mathrm{z}$ radzieckim ambasadorem $\mathrm{w}$ Waszyngtonie Maksimem Litwinowem kierujący

2000, 3 (32), s. 119-134; R. Žáček, Projekt československo-polské konfederace $v$ letech 1939-1943, Opava 2001, s. 41.

9 ZNO, PKS, sygn. 16528/II, Rozmowa gen. Sikorskiego z ministrem Edenem $w$ obecności J. Retingera, Londyn 4.07.1941, s. 100.

10 W pałacu św. Jakuba; Nieprzejednana walka do zwycięstwa (przemówienie Sikorskiego), DP, 14.06.1941, nr 284, s. 2-3; Deklaracja polsko-sowiecka; W imię wolności, DP, 6.12.1941, nr 434, s. 1, 3; Archiwum Akt Nowych, Delegatura Rządu na Kraj (DR), Departament Informacji i Prasy (DIP), sygn. 202/III-68/A, Konferencja w pałacu św. Jakuba, Radio Londyn 13.06.1941, s. 90; H. Batowski, Polska dyplomacja na obczyźnie 1939-1941, Kraków 1991, s. 356-357.

11 ZNO, PKS, sygn. 16531/II, Sprawozdanie z podróży na Średni Wschód i do Rosji, nr 23/III/42, 13 I 1942, s. 47-54; Notatka ze śniadania gen. Sikorskiego z premierem Churchillem na Downing Street 10, 11 III 1942, s. 31-33; Depesza nr 226 Raczyńskiego do Ambasadora RP w Waszyngtonie, Londyn 12 IV 1942, s. 60; Instytut Polski i Muzeum im. gen. Sikorskiego w Londynie (IPMS), sygn. PRM67, Memorandum do rząu Wielkiej Brytanii, 27.03.1942, s. 80-89. 
tral Europe ${ }^{12}$. Again, the USSR protested after an interview with E. Raczyński in January 1942 for The Sunday Times. He outlined a plan for Central-European integration based on Polish-Czechoslovak relations (with Lithuania, Hungary and Romania) and Yugoslavian-Greek (with Bulgaria) with a common economic area. They would have good-neighborly relations with the USSR ${ }^{13}$. In February 1942, the Soviet government facing a Czechoslovak ambassador in Moscow, Zdenek Fierlinger, reacted negatively to the Polish-Czechoslovak confederation ${ }^{14}$. He considered the relations of states in Europe to be a strategic game of London to stop its expansion into the Balkans, Germany and Scandinavia $^{15}$. They were the strongholds of bourgeois nationalism, the capitalist oppression of working masses and national minorities. These problems causing the wars were dissolve within the framework of the Soviet

12 E. Raczyński, Od Genewy do Jałty, rozmowy radiowe Edward Raczyński - Tadeusz Żenczykowski, Londyn 1988, pp. 52-54.

${ }^{13}$ Kluczowa pozycja Polski w Europie, DP, 12.01.1942, No. 463, p. 1-4; E. Raczyński, W sojuszniczym Londynie, p. 129.

14 ZNO, PKS, sygn. 16531/II, Rozmowa Sikorski-Eden, Londyn 8.06.1942, pp. 71-74; H. Bartoszewicz, Związek Radziecki wobec federacyjnych koncepcji w Europie Środkowo-Wschodniej 1941-1948, [in:] $Z$ dziejów prób integracji europejskiej od średniowiecza do współczesności, edit. M. Pułaski, Kraków 1995, pp. 139-142; E. Duraczyński, ZSRR wobec projektów konfederacji polsko-czechosłowackiej (1940-1943), "Dzieje Najnowsze" 1997, 3, pp. 129-153.

15 Wielki związek 16 republik, "Czerwony Sztandar” (CS), 9.08.1940, No. 268, p. 1; Konstytucja zwycięskiego socjalizmu; Dzień radości narodów kraju rad, CS, 5.12.1940, No. 367, pp. 1, 5; Bojowy sztab międzynarodowego proletariatu, CS, 4.03.1941, No. 52, p. 5 (organ Wydziału Politycznego Frontu Ukraińskiego); D.R. Marples, Historia ZSRR od rewolucji do rozpadu, Wrocław 2006, pp. 148-149; R. Pipes, Rosja bolszewików, Warszawa 2005, pp. 159-161.
MSZ Edward Raczyński napisał, że sprzeciwił się polskim planom sfederowania Europy Środkowej ${ }^{12}$. Ponownie ZSRR zaprotestował po wywiadzie E. Raczyńskiego ze stycznia 1942 r. dla „The Sunday Times'a”. Zarysował w nim plan integracji środkowoeuropejskiej, opierając się na związkach polsko-czechosłowackich (z Litwą, Węgrami i Rumunią) i jugosłowiańsko-greckich (z Bułgarią) ze wspólnym obszarem gospodarczym. Z ZSRR zawarłyby dobrosąsiedzkie stosunki ${ }^{13}$. W lutym 1942 r. wobec czechosłowackiego ambasadora w Moskwie Zdenka Fierlingera radziecki rząd ustosunkował się negatywnie do konfederacji polsko-czechosłowackiej ${ }^{14}$. Uważał związki państw w Europie za strategiczną grę Londynu dla powstrzymania jego ekspansji na Bałkany, Niemcy i Skandynawię $e^{15}$. Stanowiły ostoje burżuazyjnego nacjonalizmu, kapitalistycznego ucisku mas pracujących i mniejszości narodowych. Te problemy

12 E. Raczyński, Od Genewy do Jalty, rozmowy radiowe Edward Raczyński - Tadeusz Żenczykowski, Londyn 1988, s. 52-54.

${ }^{13}$ Kluczowa pozycja Polski w Europie, DP, 12.01.1942, nr 463, s. 1-4; E. Raczyński, $W$ sojuszniczym Londynie, s. 129.

14 ZNO, PKS, sygn. 16531/II, Rozmowa SikorskiEden, Londyn 8.06.1942, s. 71-74; H. Bartoszewicz, Zwiazek Radziecki wobec federacyjnych koncepcji w Europie Środkowo-Wschodniej 1941-1948, [w:] $Z$ dziejów prób integracji europejskiej od średniowiecza do wspótczesności, red. M. Pułaski, Kraków 1995, s. 139-142; E. Duraczyński, ZSRR wobec projektów konfederacji polsko-czechosłowackiej (1940-1943), „Dzieje Najnowsze” 1997, nr 3, s. 129-153.

${ }^{15}$ Wielki związek 16 republik, ,Czerwony Sztandar" (CS), 9.08.1940, nr 268, s. 1; Konstytucja zwycięskiego socjalizmu; Dzień radości narodów kraju rad, CS, 5.12.1940, nr 367, s. 1, 5; Bojowy sztab międzynarodowego proletariatu, CS, 4.03.1941, nr 52, s. 5 (organ Wydziału Politycznego Frontu Ukraińskiego); D.R. Marples, Historia ZSRR od rewolucji do rozpadu, Wrocław 2006, s. 148-149; R. Pipes, Rosja bolszewików, Warszawa 2005, s. 159-161. 
Union. In the agreements with the Baltic States and Finland in 1939-1940 it ordered the dissolution of the existing unions (Baltic Entente) $)^{16}$ or banned joining them (Finland with Scandinavian countries) ${ }^{17}$.

Under the influence of the USSR, E. Beneš agreed on the anti-German community of Slav countries. In his book New Slavic Policy he wrote that it was a justification for his pro-Soviet policy ${ }^{18}$. In December 1943, in Moscow, he signed with the USSR a treaty of friendship and mutual assistance against Germany for 20 years ${ }^{19}$. The agreement overruled the Polish concept of the Central European federation ${ }^{20}$.

16 Komunikat TASS o likwidacji konfliktu radziecko-litewskiego, CS, 16.06.1940, No. 222, p. 1; Komunikat TASS o stosunkach radziecko-łotewskich i radziecko-estońskich, CS, 17.06.1940, No. 223, p. 1; Estonia rozwiązała traktat porozumienia i wspótpracy między Estonią, Łotwa i Litwą, CS, 3.07.1940, No. 236, p. 4; Anulowanie przez Litwe traktatu porozumienia i wspótpracy między Estonia, Łotwa i Litwa, CS, 4.07.1940, No. 237, p. 4.

17 Traktat pokojowy między ZSRR a Republika Finska, CS, 14.03.1940, No. 143, p. 1; O przeksztatceniu Karelskiej Autonomicznej Socjalistycznej Republiki Rad w Związkowa Karelsko-Fińska Socjalistyczna Republikę Rad, CS, 1.04.1940, No. 160, p. 4; Referat o polityce zagranicznej rzadu, CS, 1.04.1940, No. 160, p. 3; Umowa rozejmowa między Związkiem Sowieckich Socjalistycznych Republik oraz Zjednoczonym Królestwem Wielkiej Brytanii i Irlandii Północnej $z$ jednej, a $z$ Finlandia $z$ drugiej strony, CS, 22.09.1944, No. 30, p. 2.

18 ZNO, PKS, sygn. 16531/II, Scripta monent (recenzja Nowej polityki słowiańskiej), "Listy z Londynu”, 7.05.1943, No. 5, p. 108; J. R. Sielezin, op. cit., p. 158 (Czech realist ended after the war in the same camp as the romantic Pole).

19 Pakt czesko-sowiecki, DP, 13.12.1943, No. 1053, p 1; Układ czechosłowacko-sowiecki, DP, 14.12.1943, No. 1054, p 2; Moskwa zaprasza Polskę, DP, 15.12.1943, No. 1055, p. 2; Zaproszenie pod adresem Polski, DP, 16.12.1943, No. 1056, p. 2; Polska a pakt czesko-sowiecki, DP, 18.12.1943, No. 1058, p. 1; Rosja oczekuje inicjatywy polskiej?, DP, 20.12.1943, No. 1059 , p. 1.

20 Tworzenie bariery przeciw Niemcom, DP, wywołujące wojny rozwiązał w ramach radzieckiej unii. W umowach z krajami bałtyckimi i z Finlandią w latach 1939-1940 nakazał rozwiązanie istniejących związków (Ententa Bałtycka $)^{16}$ lub zakazał wstępowania do nich (Finlandii z krajami skandynawskimi $)^{17}$.

Pod wpływem ZSRR E. Beneš zgodził się na antyniemiecką wspólnotę państw słowiańskich. W książce Nowa polityka słowiańska napisał, że stanowiła uzasadnienie jego proradzieckiej polityki ${ }^{18}$. W grudniu 1943 r. w Moskwie zawarł z ZSRR układ o przyjaźni i wzajemnej pomocy przeciwko Niemcom na 20 lat $^{19}$. Układ przekreślił

16 Komunikat TASS o likwidacji konfliktu radziecko-litewskiego, CS, 16.06.1940, nr 222, s. 1; Komunikat TASS o stosunkach radziecko-łotewskich i radziecko-estońskich, CS, 17.06.1940, nr 223, s. 1; Estonia rozwiązała traktat porozumienia $i$ wspótpracy miedzy Estonia, Łotwa i Litwa, CS, 3.07.1940, nr 236, s. 4; Anulowanie przez Litwę traktatu porozumienia $i$ współpracy między Estonią, Łotwą $i$ Litwa, CS, 4.07.1940, nr 237, s. 4.

17 Traktat pokojowy między ZSRR a Republikg Fińska, CS, 14.03.1940, nr 143, s. 1; O przeksztatceniu Karelskiej Autonomicznej Socjalistycznej Republiki Rad w Związkowa Karelsko-Fińska Socjalistycznq Republikę Rad, CS, 1.04.1940, nr 160, s. 4; Referat o polityce zagranicznej rzadu, CS, 1.04.1940, nr 160, s. 3; Umowa rozejmowa między Związkiem Sowieckich Socjalistycznych Republik oraz Zjednoczonym Królestwem Wielkiej Brytanii i Irlandii Pótnocnej z jednej, a $z$ Finlandia $z$ drugiej strony, CS, 22.09.1944, nr 30, s. 2.

18 ZNO, PKS, sygn. 16531/II, Scripta monent (recenzja Nowej polityki słowiańskiej), „Listy z Londynu", 7.05.1943, nr 5, s. 108; J.R. Sielezin, op. cit., s. 158 (realista Czech skończył po wojnie w tym samym obozie co romantyk Polak).

19 Pakt czesko-sowiecki, DP, 13.12.1943, nr 1053, s. 1; Układ czechosłowacko-sowiecki, DP, 14.12.1943, nr 1054, s. 2; Moskwa zaprasza Polske, DP, 15.12.1943, nr 1055, s. 2; Zaproszenie pod adresem Polski, DP, 16.12.1943, nr 1056, s. 2; Polska a pakt czesko-sowiecki, DP, 18.12.1943, nr 1058, s. 1; Rosja oczekuje inicjatywy polskiej?, DP, 20.12.1943, nr 1059, s. 1 . 
According to E. Beneš, it was part of the world security system of the Big Three and the protection of the Slav nations against Germany ${ }^{21}$. He emphasized that Czechoslovakia and USSR had a natural bond of friendship. Poland's participation in the anti-German unification of Slavic nations was a central issue for peace in Central Europe. He did not see return to Pan-Slavism in the Slavic union ${ }^{22}$. In his book $S$ východem a západem (London, 1944), Deputy Foreign Minister Hubert Ripka argued that small nations of Western Europe should federate with each other with the help of London and Paris, and the ones of Central Europe of Moscow, a real barrier against Germany $^{23}$. In the Pan-Slavonic Committee prof. Zdeněk Nejedlý emphasized that only the Slavic Soviet Union could liberate Czechoslovakia. After the war, the Slav nations should unite around it. The Moscow "Československé list" wrote that the Czechoslovak troops (Czechs, Slovaks,

15.12.1943, No. 1055, p. 4; Gdzie się kończą sprawy wewnętrzne, a gdzie zaczynaja sowieckie stosunki międzynarodowe, DP, 17.12.1943, No. 1057, p 2; Echa sojuszu czesko-sowieckiego, DP, 20.12.1943, No. 1059, p. 2; ZNO, Papiery Klaudiusza Hrabyka (PKH), sygn. 16353/II; T. Komarnicki, Uwagi w sprawie projektów organizacji państw Europy Wschodniej i Południowo-Wschodniej, Londyn 14.09.1948, p. 134; V. Smetana, Konfederacja czechosłowacko-polska a polityka mocarstw, [in:] Między przymusowa przyjaźnią a prawdziwa solidarnością..., part 1, p. 131.

21 AMR, Narodowe Siły Zbrojne (NSZ), sygn. 207/19, Oświadczenie prezydenta Edvarda Beneša na konferencji prasowej w Moskwie, Radio Moskwa (audycja polska), 23.12.1943, pp. 67-69; R. Žáček, op. cit., p. 23.

22 Beneš: pragniemy współpracy z Polską, DP, 23.12.1943, No. 1062, p. 1.

23 Beneš brnie dalej, "Kraj”, 15.02.1944, No. 7, p. 8 (organ Delegatury); "Prawda" o Czechosłowacji, "Rzeczpospolita", 28.03.1945, No. 82, p. 2 (organ komunistycznego Rządu Tymczasowego). polską koncepcję federacji Europy Środkowej ${ }^{20}$. Zdaniem E. Beneša był on częścią światowego systemu bezpieczeństwa Wielkiej Trójki i zabezpieczeniem narodów słowiańskich przed Niemcami ${ }^{21}$. Podkreślał, że Czechosłowację i ZSRR łączyły naturalne więzi przyjaźni. Udział Polski w antyniemieckim zjednoczeniu narodów słowiańskich był zasadniczą kwestią dla pokoju w Europie Środkowej. Nie widział $\mathrm{w}$ unii słowiańskiej powrotu do panslawizmu ${ }^{22}$. W książce $S$ východem a západem (Londyn 1944) wiceminister spraw zagranicznych Hubert Ripka twierdził, że małe narody Europy Zachodniej powinny sfederować się z pomocą Londynu i Paryża, a Europy Środkowej - Moskwy, realnej bariery przed Niemcami ${ }^{23}$. W Komitecie Wszechsłowiańskim prof. Zdeněk Nejedlý podkreślał, że tylko słowiański ZSRR mógł wyzwolić Czechosłowację. Po wojnie narody słowiańskie powinny się zjednoczyć wokół niego. Moskiewskie „Českosloven-

20 Tworzenie bariery przeciw Niemcom, DP, 15.12.1943, nr 1055, s. 4; Gdzie się kończa sprawy wewnętrzne, a gdzie zaczynaja sowieckie stosunki międzynarodowe, DP, 17.12.1943, nr 1057, s. 2; Echa sojuszu czesko-sowieckiego, DP, 20.12.1943, nr 1059, s. 2; ZNO, Papiery Klaudiusza Hrabyka (PKH), sygn. 16353/II; T. Komarnicki, Uwagi w sprawie projektów organizacji państw Europy Wschodniej i Południowo-Wschodniej, Londyn 14.09.1948, s. 134; V. Smetana, Konfederacja czechosłowacko-polska a polityka mocarstw, [w:] Między przymusową przyjaźnią a prawdziwą solidarnością..., cz. 1, s. 131.

21 AAN, Narodowe Siły Zbrojne (NSZ), sygn. 207/19, Oświadczenie prezydenta Edvarda Beneša na konferencji prasowej w Moskwie, Radio Moskwa (audycja polska), 23.12.1943, s. 67-69; R. Žáček, op. cit., s. 23.

22 Beneš: pragniemy współpracy z Polską, DP, 23.12.1943, nr 1062, s. 1.

23 Beneš brnie dalej, „Kraj”, 15.02.1944, nr 7, s. 8 (organ Delegatury); „Prawda” o Czechosłowacji, „Rzeczpospolita”, 28.03.1945, nr 82, s. 2 (organ komunistycznego Rządu Tymczasowego). 
Ukrainians of the Podkarpacie region) together with the Red Army carried freedom and democracy of the Slav countries ${ }^{24}$.

After the German aggression in June 1941, the USSR abandoned the view of the imperialist war that was triggered in 1939 by capitalist states ${ }^{25}$, during which it led the policy of peace and proletarian internationalism ${ }^{26}$. It convinced that the pact with Germans gave it time to prepare for an inevitable war with them ${ }^{27}$. The conquest of neighboring states resulted from strategic defense against Germany ${ }^{28}$. In 1938-1941 the USSR did not defend allied Czechoslovakia and Yugoslavia against Germany. In September 1939, it together with Germany attacked Poland, and until 1941 the Soviet Union exterminated the "Polish Slavs" in the same way as Germans ${ }^{29}$. In 1941, it began to propagate the Slavic idea, which since the October Revolution it had defined as a bourgeois anachronism, breaking the proletarian unity. The Moscow Pan-Slavonic Committee (the first congress of 11-12 August) called for the Slavic fraternity and the fight against

24 Z prasy czeskiej, "Wolna Polska”, 15.03.1944, No. 10, p. 3 (Związek Patriotów Polskich).

${ }^{25}$ Prasa francuska $i$ włoska o angielsko-francuskich planach podziału Europy, CS, 8.04.1940, No. 166, p. 4; Bojowy sztab międzynarodowego proletariatu, CS, 4.03.1941, No. 52, p. 5; Historyczny XVIII Zjazd bolszewików, CS, 11.03.1941, No. 58, p. 4.

${ }^{26}$ XXII rocznica Rewolucji Październikowej, CS, 11.11.1939, No. 41, p. 1; Polityka zagraniczna wielkiego kraju socjalistycznego ("Prawda", 3.08.1940), CS, 4.08.1940, No. 264, p. 1.

27 Stalin o,drugim froncie” i o przyczynach sukcesów niemieckich, "Naród i Wojsko", grudzień 1941, No. 2, p. 11 (Grupa "Szańca”).

28 T. Szarota, Życie codzienne w stolicach okupowanej Europy, Warszawa 1995, p. 161.

29 Generat-Gubernatorstwo ("Prawda", 25.01.1940), CS, 28.01.1941, No. 22, p. 5. ské listy" napisały, że wojska czechosłowackie (Czesi, Słowacy, Ukraińcy Podkarpaccy) razem z Armią Czerwoną niosły wolność i demokrację Słowiańszczyźnie ${ }^{24}$.

Po niemieckiej agresji w czerwcu $1941 \mathrm{r}$. ZSRR porzucił pogląd o imperialistycznej wojnie wywołanej w 1939 r. przez państwa kapitalistyczne ${ }^{25}$, w czasie której prowadził politykę pokoju i proletariackiego internacjonalizmu ${ }^{26}$. Przekonywał, że pakt z Niemcami dał mu czas na przygotowanie się do nieuniknionej z nimi wojny ${ }^{27}$. Zabory sąsiednich państw wynikały ze strategicznej obrony przed Niemca$\mathrm{mi}^{28}$. W latach 1938-1941 ZSRR nie bronił przed Niemcami sojuszniczej Czechosłowacji i Jugosławii. We wrześniu 1939 r. napadł z nimi na Polskę, a do 1941 r. "polskich Słowian” eksterminował tak samo jak Niemcy ${ }^{29}$. W 1941 r. przystąpił do propagowania idei słowiańskiej, którą od rewolucji październikowej określał burżuazyjnym anachronizmem, rozbijającym proletariacką jedność. Moskiewski Komitet Wszechsłowiański (pierwszy kongres 11-12 sierpnia) wzywał do braterstwa sło-

24 Z prasy czeskiej, „Wolna Polska”, 15.03.1944, nr 10, s. 3 (Związek Patriotów Polskich).

25 Prasa francuska $i$ włoska o angielsko-francuskich planach podziału Europy, CS, 8.04.1940, nr 166, s. 4; Bojowy sztab międzynarodowego proletariatu, CS, 4.03.1941, nr 52, s. 5; Historyczny XVIII Zjazd bolszewików, CS, 11.03.1941, nr 58, s. 4.

${ }^{26}$ XXII rocznica Rewolucji Październikowej, CS, 11.11.1939, nr 41, s. 1; Polityka zagraniczna wielkiego kraju socjalistycznego („Prawda”, 3.08.1940), CS, 4.08.1940, nr 264, s. 1.

27 Stalin o,drugim froncie” i o przyczynach sukcesów niemieckich, „Naród i Wojsko”, grudzień 1941, nr 2, s. 11 (Grupa „Szańca”).

28 T. Szarota, Życie codzienne w stolicach okupowanej Europy, Warszawa 1995, s. 161.

29 Generat-Gubernatorstwo ( Prawda”, 25.01.1940), CS, 28.01.1941, nr 22, s. 5. 
the common enemy of the Slavs ${ }^{30}$. At the annual rallies representatives of the various national sections spoke who were celebrating Stalin, the Slavic Red Army (Russians, Belarussians, Ukrainians) and the unity of the Slavs. The Slav nations were called upon to fight armed and to create national committees headed by Communists ${ }^{31}$. Stalin announced the liberation and destruction of their oppressors by the Red Army. Victory over Germany was guaranteed by their political and military unity at the head of the most powerful Slavic state. Uniting antagonistic Slavic states led to the organized anti-German resistance in occupied Europe, with particular activity of Slavic guerrilla ${ }^{32}$. Maintaining their unity was essential to their security and Europe ${ }^{33}$. In occupied Poland, com-

30 Marszałek Tito w Komitecie Wszechsłowiańskim w Moskwie, "Wolna Polska", 19.04.1945, No. 15 , p. 1 (ZPP); S. Fertacz, Komitet Wszechsłowiański w Moskwie 1941-1947, Katowice 1991, pp. 65-74.

31 AMR, NSZ, sygn. 207/8, Za jedność Słowian, "Partyzant", 20.03.1944 (Wiec słowiańskich formacji wojskowych w Moskwie 23.02.1944 z okazji 26. rocznicy powstania Armii Czerwonej), p. 38, (Komunistyczny organ Centralnego Ruchu Partyzanckiego na Zachodniej Ukrainie); sygn. 220/21, Wszechsłowiański Kongres w Moskwie, 11-12.08.1941, pp. 1-10; II Kongres Wszechsłowiański w Moskwie, 4.04.1942, pp. 11-19; Komenda Główna Armii Krajowej (KGAK), Biuro Informacji i Propagandy (BIP), sygn. 203/VII-62, III Kongres Narodów Słowiańskich w Moskwie, 9.05.1943, p. 128; DR, DIP, sygn. 202/III-31, Metody i cele sowieckiej okupacji w Polsce, Idea Wszechsłowiańska idea pomocniczą, "Dokumenty Chwili" 1945, No. 3, pp. 145-146; sygn. 202/III-73, Wiec czechosłowackiej sekcji Komitetu Wszechsłowiańskiego, Radio Moskwa, serwis 362/42, 15.03.1944, p. 6.

32 AMR, NSZ, sygn. 207/8, 24 rocznica wielkiej socjalistycznej rewolucji październikowej (przemówienie Stalina), Moskwa 6.11.1941, p. 13; Precz ze zdrajcami słowiańskich narodów, "Partyzant", 20.03.1944, p. 37.

33 AMR, DR, DIP, sygn. 202/III-73, Artykut wiańskiego i walki ze wspólnym wrogiem Słowian $^{30}$. Na corocznych wiecach przemawiali przedstawiciele poszczególnych sekcji narodowych, sławiąc Stalina, słowiańską Armię Czerwoną (Rosjanie, Białorusini, Ukraińcy) i jedność Słowian. Wzywano narody słowiańskie do walki zbrojnej i tworzenia komitetów narodowych na czele z komunistami ${ }^{31}$. Stalin zapowiadał wyzwolenie i zniszczenie ich ciemiężców przez Armię Czerwoną. Zwycięstwo nad Niemcami gwarantowała ich jedność polityczna i militarna na czele $\mathrm{z}$ najpotężniejszym państwem słowiańskim. Zjednoczenie skłóconych państw słowiańskich dało zorganizowany antyniemiecki opór w okupowanej Europie, ze szczególną aktywnością partyzantki słowiańskiej ${ }^{32}$. Utrzymanie ich jedności było niezbędne dla ich bezpieczeństwa i Europy ${ }^{33}$. W okupowa-

30 Marszałek Tito w Komitecie Wszechsłowiańskim w Moskwie, „Wolna Polska”, 19.04.1945, nr 15, s. 1 (ZPP); S. Fertacz, Komitet Wszechsłowiański w Moskwie 1941-1947, Katowice 1991, s. 65-74.

31 AAN, NSZ, sygn. 207/8, Za jedność Słowian, „Partyzant”, 20.03.1944 (Wiec słowiańskich formacji wojskowych w Moskwie 23.02.1944 z okazji 26. rocznicy powstania Armii Czerwonej), s. 38 (Komunistyczny organ Centralnego Ruchu Partyzanckiego na Zachodniej Ukrainie); sygn. 220/21, Wszechstowiański Kongres w Moskwie, 11-12.08.1941, s. 1-10; II Kongres Wszechsłowiański w Moskwie, 4.04.1942, s. 11-19; Komenda Główna Armii Krajowej (KGAK), Biuro Informacji i Propagandy (BIP), sygn. 203/VII62, III Kongres Narodów Słowiańskich w Moskwie, 9.05.1943, s. 128; DR, DIP, sygn. 202/III-31, Metody i cele sowieckiej okupacji w Polsce, Idea Wszechsłowiańska idea pomocniczą, „Dokumenty Chwili” 1945, nr 3, s. 145-146; sygn. 202/III-73, Wiec czechosłowackiej sekcji Komitetu Wszechsłowiańskiego, Radio Moskwa, serwis 362/42, 15.03.1944, s. 6.

32 AAN, NSZ, sygn. 207/8, 24 rocznica wielkiej socjalistycznej rewolucji październikowej (przemówienie Stalina), Moskwa 6.11.1941, s. 13; Precz ze zdrajcami słowiańskich narodów, „Partyzant”, 20.03.1944, s. 37.

33 AAN, DR, DIP, sygn. 202/III-73, Artykut 
munists copied the slogans of the Pan-Slavonic Committee ${ }^{34}$. Its affiliates were created in 1942 in the United States and Great Britain among pro-communist emigrants of Slavonic origin ${ }^{35}$.

Polish soldiers (col. Zygmunt Berling), Czechoslovak (col. Ludvík Svoboda) and Yugoslav (col. Marko Mesić) guerrillas in the Soviet Union and Yugoslavia, Czechoslovakia and the Poland fought for Slavic unity at the side of the Red Army under the leadership of the Communists. Bulgarians could wash away the shame of cooperation with the Germans, joining the armed struggle against them ${ }^{36}$. Traitors of the Slavic idea were cooperating with the Germans bourgeois nationalists, reactionaries and fascists in the Protectorate of Bohemia and Moravia, Slovakia, the Free State of Croatian and Bulgary, Ukrainian and Belarusian nationalists, Polish and Yugoslavian émigré governments and their subordinate armies in exile and in the country (military forces of General Dragoljub Mihailovic, National Army, National Armed Forces and Polish Underground State as a whole) ${ }^{37}$. After taking

Andrzeja Witosa, Radio Moskwa, serwis 362/42, 15.03.1944, p. 5; Kwestia słowiańska i jej znaczenie, “Życie Słowiańskie” (ŻS) 1946, No. 3, pp. 97-101.

34 Kongres Narodów Słowiańskich, "Głos Warszawy", 11.05.1943, p. 12, (PPR).

35 AMR, Wszechsłowiański Komitet w Wielkiej Brytanii (WKWB), sygn. 220/21, Wszechsłowiańskie Komitety w Stanach Zjednoczonych i Wielkiej Brytanii, p. 21.

36 AMR, DR, DIP, sygn. 202/III-41, Depesza $z$ plenum Komitetu Wszechsłowiańskiego do 1. Korpusu Polskich Sił Zbrojnych w ZSRR, meldunek RAKu do "L", CIN/XX-720, 10.12.1943, p. 14; NSZ, sygn. 207/8, Za jedność Słowian, "Partyzant", 20.03.1944, p. 38 .

37 AMR, NSZ sygn. 207/8, Precz ze zdrajcami słowiańskich narodów; Za jedność Słowian, "Party- nej Polsce komuniści powielali hasła Komitetu Wszechsłowiańskiego ${ }^{34}$. Jego filie powstały w 1942 r. w Stanach Zjednoczonych i Wielkiej Brytanii wśród prokomunistycznych emigrantów pochodzenia słowiańskiego $^{35}$.

O jedność słowiańską u boku Armii Czerwonej walczyli żołnierze polscy (płk. Zygmunt Berling), czechosłowaccy (płk. Ludvík Svoboda) i jugosłowiańscy (płk. Marko Mesić) w ZSRR oraz partyzanci Jugosławii, Czechosłowacji i Polski pod wodzą komunistów. Bułgarzy mogli zmyć hańbę współpracy z Niemcami, przystępując z nimi do walki zbrojnej ${ }^{36}$. Zdrajcami sprawy słowiańskiej byli współpracujący z Niemcami burżuazyjni nacjonaliści, reakcjoniści i faszyści w Protektoracie Czech i Moraw, Słowacji, Wolnym Państwie Chorwackim i Bułgarii, ukraińscy i białoruscy nacjonaliści, emigracyjne rządy Polski i Jugosławii oraz podległe im wojska na emigracji i w kraju (oddziały generała Dragoljuba Mihajlovićia, Armia Krajowa, Narodowe Siły Zbrojne i Polskie Państwo Podziemne jako całość) ${ }^{37}$. Po za-

Andrzeja Witosa, Radio Moskwa, serwis 362/42, 15.03.1944, s. 5; Kwestia słowiańska i jej znaczenie, „Życie Słowiańskie” (ŻS) 1946, nr 3, s. 97-101.

34 Kongres Narodów Słowiańskich, „Głos Warszawy", 11.05.1943, s. 12 (PPR).

35 AAN, Wszechsłowiański Komitet w Wielkiej Brytanii (WKWB), sygn. 220/21, Wszechsłowiańskie Komitety w Stanach Zjednoczonych $i$ Wielkiej Brytanii, s. 21.

36 AAN, DR, DIP, sygn. 202/III-41, Depesza z 6 plenum Komitetu Wszechsłowiańskiego do 1. Korpusu Polskich Sił Zbrojnych w ZSRR, meldunek RAKu do „L”, CIN/XX-720, 10.12.1943, s. 14; NSZ, sygn. 207/8, Za jedność Słowian, „Partyzant”, 20.03.1944, s. 38.

37 AAN, NSZ sygn. 207/8, Precz ze zdrajcami słowiańskich narodów; Za jedność Słowian, „Partyzant”, 20.03.1944, s. 37-38; Odezwa do obywateli Ob- 
over Central and Southern Europe in 1945 by the Red Army, Slavic Committees were formed in Bulgaria (1944), Czechoslovakia, Yugoslavia and Poland ${ }^{38}$. Polish communists justified that geopolitically Poland had no other option but Slavic uni$t^{39}$. In the "democratic" Poland the Slavic idea was to replace "imperial" Jagiellonian idea, which expanded the borders of Poland on the Ukrainian, Belarusian, Russian and Lithuanian lands ${ }^{40}$. A strong, secure and democratic Poland could only exist on the lands of the Piast without national minorities in the east and in the anti-Nazi Slavic alliance led by the Soviet Union ${ }^{41}$. In fact, the Slavic idea was justification for the Soviet Union's imperial objectives in Central Europe. This was a good example of the Sorbian affair, which the Polish Slavic Committee demanded ${ }^{42}$. The USSR did not

zant", 20.03.1944, p. 37-38; Odezwa do obywateli Obwodu Lwowskiego, Wojskowa Rada Organizacji Ruchu Partyzanckiego, 9.03.1944, p. 40.

38 Utworzenie Komitetu Słowiańskiego, ŻS 1946, No. 1, pp. 31-32 (The Slavonic Committee was established in 1945 in Warsaw. He published "Slavic Life". The presidium was chaired by: Mieczysław Michałowicz, deputy Henryk Batowski, J. Kostrzewski and Władysław Kowalski, secretary P. Dąbek, J. Czekanowski, S. Fedecki, K. Gruszczyński, J. Kornacki, Tadeusz Lehr-Spławiński, J. Loth, Edward Ochab, priest Czeslaw Oraczewski, col. K. Sidor, Henryk Świątkowski, S. Wilanowski).

39 Ogniwa jednego łańcucha, CS, 6.01.1945, No 4, p. 2.

40 Skończmy z wrogami narodu polskiego, CS, 6.02.1945, No. 26, p. 1.

41 Związek Radziecki a demokratyczna Polska ("Prawda", 7.01.1945), CS, 9.01.1945, No. 6, p. 1; Linia Curzona, CS, 24.02.1945, No. 39, p. 2; Niemcy odwieczni wrogowie narodu polskiego, CS, 6.04.1945, No. 46 , p. 3.

42 Łużycom, ŻS, 1946, No. 1, pp. 16-17; Łużycom, ŻS 1946, No. 3, p. 77-79; H. Batowski, Kwestia słowiańska i jej znaczenie dla Polski, ŻS 1946, No. 3, pp. 98-100, (He believed that it was a matter of honor the support of the Slavs for the state of jęciu przez Armię Czerwoną Europy Środkowej i Południowej w 1945 r. powstawały Komitety Słowiańskie w Bułgarii (1944), Czechosłowacji, Jugosławii i Polsce ${ }^{38}$. Polscy komuniści uzasadniali, że geopolitycznie Polska była skazana na jedność słowiańską ${ }^{39}$. Idea słowiańska miała zastąpić w „demokratycznej” Polsce „imperialną" ideę jagiellońską, która rozszerzała polskie granice na ziemie ukraińskie, białoruskie, rosyjskie i litewskie ${ }^{40}$. Silna, bezpieczna i demokratyczna Polska mogła istnieć tylko na ziemiach piastowskich bez mniejszości narodowych na wschodzie i w antyniemieckim sojuszu słowiańskim na czele z ZSRR ${ }^{41}$. W rzeczywistości idea słowiańska stanowiła uzasadnienie dla imperialnych celów ZSRR w Europie Środkowej. Dobrze oddawała to sprawa serbołużycka, o którą upominał się Polski Komitet Słowiański ${ }^{42}$.ZSRR nie widział tego problemu

wodu Lwowskiego, Wojskowa Rada Organizacji Ruchu Partyzanckiego, 9.03.1944, s. 40.

38 Utworzenie Komitetu Słowiańskiego, ŻS 1946, nr 1, s. 31-32 (Komitet Słowiański powstał w 1945 r. w Warszawie. Wydawał „Życie Słowiańskie”. W prezydium zasiedli: przewodniczący Mieczysław Michałowicz, zastępcy Henryk Batowski, J. Kostrzewski i Władysław Kowalski, sekretarz P. Dąbek, J. Czekanowski, S. Fedecki, K. Gruszczyński, J. Kornacki, Tadeusz Lehr-Spławiński, J. Loth, płk. Edward Ochab, ksiądz Czesław Oraczewski, płk. K. Sidor, Henryk Świątkowski, S. Wilanowski).

39 Ogniwa jednego łańcucha, CS, 6.01.1945, nr 4, s. 2.

40 Skończmy z wrogami narodu polskiego, CS, 6.02.1945, nr 26, s. 1 .

41 Zwiazek Radziecki a demokratyczna Polska („Prawda”, 7.01.1945), CS, 9.01.1945, nr 6, s. 1; Linia Curzona, CS, 24.02.1945, nr 39, s. 2; Niemcy odwieczni wrogowie narodu polskiego, CS, 6.04.1945, nr 46, s. 3.

42 Łużycom, ŻS, 1946, nr 1, s. 16-17; Łużycom, ŻS 1946, nr 3, s. 77-79; H. Batowski, Kwestia słowiańska i jej znaczenie dla Polski, ŻS 1946, nr 3, s. 98-100 (Uważał, że sprawą honoru było poparcie 
see this problem in the context of the security of the Slavic states and peoples. Slavic unity served only the interests of the Soviet Union, and not the Slavs as a whole.

The Slavic idea also spread Among the Polish emigration. In the years 1940-1941 the West-Slavonic Committee worked in Bucharest and later in London. The martyrdom of the Slavs it saw in their disobedience and in the importance of political, ideological and religious differenc$\mathrm{es}^{43}$. Their federation, including the Sorbs, would halt German imperialism. It did not exclude the USSR, but it would have to recognize Poland within the borders delimitated by the Treaty of Riga and the Chrobry line (Rügen, Upper and Lower Lusatia to the Sudeten), the Baltic coast from Rügen to the mouth of the Nemunas and the independence of Lithuania. Independent Latvia and Estonia would be in the Soviet zone of influence. At the Polish Army camp in Scotland a Polish-West Slavonic group was established in 1940 . They maintained contacts with emigrants from Central Europe. By March 1943, it published

Lusatia. It had strategic importance for Poland and Czechoslovakia); D. Miszewski, Łużyce ziemiami zachodnimi Polski w myśli politycznej Polski podziemnej w czasie II wojny światowej, [in:] "Ziemie Odzyskane" po drugiej wojnie światowej, edit. C. Osękowski, G. Strauchold, Zielona Góra 2015, pp. 169-185.

43 AMR, Polskie Ugrupowania w Wielkiej Brytanii (PUWB), sygn. 220/27, Federacja Słowian Zachodnich, Komitet Zachodniosłowiański, Bukareszt 15.04.1940, pp. 18-23; J. Tyszkiewicz, Działalność Komitetu Zachodniosłowiańskiego w latach 1939-1940, "Wrocławskie Studia z Historii Najnowszej" 1997, 4, pp. 81-94; idem, Edmund Romer i projekt Federacji Stowian Zachodnich (1940-1941), [in:] Idea Europy i Polska w XIX i XX wieku, edit. J. Degler, Wrocław 1999, pp. 157-164; P. Eberhardt, Polski panslawizm jako idea geopolityczna, "Przegląd Geopolityczny" 2014, 7, pp. 71-74. w kontekście bezpieczeństwa państw i narodów słowiańskich. Jedność słowiańska służyła wyłącznie interesom ZSRR, a nie Słowiańszczyzny jako całości.

Wśród polskiej emigracji także szerzyła się idea słowiańska. W latach 19401941 w Bukareszcie, a potem w Londynie działał Komitet Zachodniosłowiański. Wojenną klęskę Słowian widział w ich skłóceniu i w przykładaniu wagi do różnic politycznych, ideowych i religijnych ${ }^{43}$. Ich federacja, łącznie z Serbołużyczanami, powstrzymałaby niemiecki imperializm. Nie wykluczał ZSRR, ale musiałby uznać Polskę w granicach ryskiej i linii Chrobrego (Rugia, Górne i Dolne Łużyce do Sudetów), wybrzeże bałtyckie od Rugii do ujścia Niemna i niepodległość Litwy. Niezależne Łotwa i Estonia znalazłyby się w radzieckiej strefie wpływów. W obozie wojsk polskich w Szkocji powstała w 1940 r. grupa polsko-zachodniosłowiańska. Utrzymywała kontakty z emigrantami z Europy Środkowej. Do marca 1943 r. wydała 10 numerów „Biuletynu Zachodniosło-

Słowin państwa łużyckiego. Dla Polski i Czechosłowacji miało ono znaczenie strategiczne); D. Miszewski, Łużyce ziemiami zachodnimi Polski w myśli politycznej Polski podziemnej w czasie II wojny światowej, [w:] „Ziemie Odzyskane” po drugiej wojnie światowej, red. C. Osękowski, G. Strauchold, Zielona Góra 2015, s. 169-185.

${ }^{43}$ AAN, Polskie Ugrupowania w Wielkiej Brytanii (PUWB), sygn. 220/27, Federacja Stowian Zachodnich, Komitet Zachodniosłowiański, Bukareszt 15.04.1940, s. 18-23; J. Tyszkiewicz, Działalność Komitetu Zachodniosłowiańskiego w latach 1939-1940, „Wrocławskie Studia z Historii Najnowszej”1997, 4, s. 81-94; idem, Edmund Romer i projekt Federacji Stowian Zachodnich (1940-1941), [w:] Idea Europy i Polska w XIX i XX wieku, red. J. Degler, Wrocław 1999, s. 157-164; P. Eberhardt, Polski panslawizm jako idea geopolityczna, „Przegląd Geopolityczny”, 2014, 7, s. 71-74. 
10 issues of the "West Slavonic Bulletin"44. Their concept was based on the ideas of the two union states of West Slavic and Balkan, joined as the Central European Union of States. Under the influence of the Red Army's victories, the group began to accept the formation of one federation in Central Europe with the capital in Slovakia in the vicinity of Košice. Romania and Hungary could have entered it, which had to return to Slovakia the land occupied since 1938 and Yugoslavia since 1941. They would have kept Subcarpathian Ruthenia and Transylvania. The group published a number of publications in Polish and English. When in 1941 the USSR began to preach the Slavic idea, W. Sikorski forbade to spread it in the Polish army ${ }^{45}$. Minister Stanisław Stroński withdrew paper for the group to issue the publications, and they never got the subsidy for their activity.

44 AMR, KGAK, BIP, sygn. 203/VII-67, Pisarczyk (Ludwik Widerszal), Sprawy środkowoeuropejskie na emigracji (rozmowa $z$ Jurem). Poufne nie do publikacji, 252/B 38/43, 22.03.1943, pp. 38-39; J. Lerski, Emisariusz Jur, Warszawa 1989; (Skład grupy m. in. Stanisław Połujan, Zygmunt Sławiński, Stefan Sulimirski, Z. Książkiewicz, Bogusław Werner, Alfred Gałuszka, Władysław Barański, Władysław Olędzki, Roman Choróbski, Wojciech Hoffman, Józef Jasnowski, Aleksander Pastewski, Lucjan Piętka, Jerzy Lerski ("Jur").

${ }^{45}$ ZNO, PKS, sygn. 16531/II, Sprawozdanie z podróży na Średni Wschód i do Rosji, No. 23/III/42, 13.01.1942, pp. 50-51 (He considered that outside of the border dispute and the desire to impose Poland on communism, the source of conflicts with the USSR was panchism, white or red is just as dangerous for us as for Western Slavs. Therefore, we must guard our refugees and soldiers in Russia from these tendencies, and in the west, to be honest with the Czechoslovak and Yugoslavs.); S. Fertacz, Polska myśl słowiańska w okresie drugiej wojny światowej, Katowice 2000, pp. 47-48. wiańskiego"44. Jej koncepcja opierała się na idei dwóch państw związkowych zachodniosłowiańskiego i bałkańskiego, połączonych w Środkowoeuropejski Związek Państw. Pod wpływem zwycięstw Armii Czerwonej grupa zaczęła się skłaniać do tworzenia jednej federacji w Europie Środkowej ze stolicą na Słowacji w okolicach Koszyc. Mogłyby wchodzić do niej Rumunia i Węgry, które musiały zwrócić Słowacji ziemie zajęte od 1938 r. i Jugosławii od 1941 r. Zachowałyby Ruś Podkarpacką i Siedmiogród. Grupa wydała wiele publikacji po polsku i angielsku. Gdy w 1941 r. ZSRR zaczął głosić ideę słowiańską, to W. Sikorski zakazał jej szerzenia w polskim wojsku ${ }^{45}$. Minister Stanisław Stroński cofnął grupie papier na pismo, a subwencji na swoją działalność nigdy nie dostała.

W czasie II wojny światowej członek Rady Narodowej Rzeczypospolitej Polskiej gen. Lucjan Żeligowski stał się gorącym zwolennikiem współpracy wszystkich

${ }^{44}$ AAN, KGAK, BIP, sygn. 203/VII-67, Pisarczyk (Ludwik Widerszal), Sprawy środkowoeuropejskie na emigracji (rozmowa $z$ Jurem). Poufne nie do publikacji, 252/B 38/43, 22.03.1943, s. 38-39; J. Lerski, Emisariusz Jur, Warszawa 1989; (Skład grupy m. in. Stanisław Połujan, Zygmunt Sławiński, Stefan Sulimirski, Z. Książkiewicz, Bogusław Werner, Alfred Gałuszka, Władysław Barański, Władysław Olędzki, Roman Choróbski, Wojciech Hoffman, Józef Jasnowski, Aleksander Pastewski, Lucjan Piętka, Jerzy Lerski („Jur”).

${ }^{45}$ ZNO, PKS, sygn. 16531/II, Sprawozdanie z podróży na Średni Wschód i do Rosji, nr 23/III/42, 13.01.1942, s. 50-51; (Uważał, że poza sporem granicznym i chęcią narzucenia Polsce komunizmu źródłem konfliktów z ZSRR był panslawizm, biały czy czerwony jest równie dla nas, jak i dla Stowian Zachodnich niebezpieczny. Dlatego musimy strzec naszych uchodźców i żolnierzy w Rosji przed tymi tendencjami, a na zachodzie porozumieć się szczerze $z$ Czechostowakami i Jugosłowianami); S. Fertacz, Polska myśl słowiańska w okresie drugiej wojny światowej, Katowice 2000, s. 47-48. 
During the Second World War, General Lucjan Żeligowski, a member of the $\mathrm{Na}$ tional Council of the Republic of Poland, became an ardent supporter of the cooperation of all Slavic peoples, who should work together to develop a new Slav card of histor $y^{46}$. In an appeal to the Poles in March 1944, he wrote to remember that they were Slavs, whose eternal enemy were the Germans. He argued that "the armies of the Soviets, together with the armies of all United Nations, are not only fighting for world freedom, but are also the armies of the Slavs, and therefore our brothers. Let us give them the hand of friendship and eternal agreement". He considered the Slavic alliance was the greatest threat to the Germans and the hope for lasting peace. After their fall, the Slavic nations would have resolved all the disputes in a righteous and justice way. Poles, Czechs and Yugoslavs were defenders of the Slavs ${ }^{47}$. In May 1944, in a letter to the chairman of the National

46 W Radzie Narodowej RP, DP, 23.05.1942, No. 574, p. 1 (Żeligowski: jedność słowiańska to pokój dla Polski. Rada odrzuciła ideę słowiańską jako szkodliwą dla Polski); PKS, sygn. 16522/II/vol.1, Gen. L. Żeligowski do Prezesa Rady Narodowej RP, Londyn 26.04.1943, p. 294; Litwa a Żmudź, DP, 15.10.1943, No. 1003, p. 3 (L. Żeligowski, Zapomniane praw$d y$, Londyn 1943); A. Pragier, Na manowcach federalizmu, RPWB, 1.04.1944, No. 7, p. 3; List gen. Żeligowskiego, "Rzeczpospolita", 2.02.1945, No. 32, p. 2; J. Sosnkowska, W kręgu mitów i rzeczywistości, Warszawa 1988, p. 18; Dzienniki Czynności Prezydenta RP Władysława Raczkiewicza 1939-1947, vol. 1 (1939-1942), edit. J. Piotrowski, Wrocław 2004, p. 135 (Żeligowski presented to the President a study on the Slavic idea and demanded a secret meeting of the National Council).

47 AMR, PUWB, sygn. 220/27, Odezwa gen. Lucjana Żeligowskiego do kraju, wręczona prezesowi Rady Narodowej 31 III 1944 r. w Londynie, p. 28; Odezwa gen. Żeligowskiego do kraju, "Rzeczpospolita", 4.08.1944, No. 2, p. 2. narodów słowiańskich, które powinny razem wypracować nową słowiańską kartę dziejów ${ }^{46}$. W odezwie do Polaków w marcu 1944 r. napisał, aby pamiętali, że byli Słowianami, których odwiecznym wrogiem byli Niemcy. Przekonywał, że „armie Sowietów, razem z armiami wszystkich Zjednoczonych Narodów, nie tylko walczą o wolność świata, lecz ponadto są armiami Słowian, a więc naszymi braćmi. Podajmy im rękę przyjaźni i wiecznej zgody”. Uważał słowiański sojusz za największą groźbę dla Niemców i nadzieję na trwały pokój. Po ich upadku słowiańskie narody rozwiązałyby sprawiedliwie i w zgodzie wszystkie spory. Polacy, Czesi i Jugosłowianie stanowili tarcze obronne dla Słowian ${ }^{47}$. W maju 1944 r. w liście do przewodniczącego Rady Narodowej Stanisława Grabskiego żądał publicznego odczytania odezwy i nadania jej przez radio do Polski. Stwierdził, że idea słowiańska mogła uratować Polskę, a jej miejsce

46 W Radzie Narodowej RP, DP, 23.05.1942, nr 574, s. 1 (Żeligowski: jedność słowiańska to pokój dla Polski. Rada odrzuciła ideę słowiańską jako szkodliwą dla Polski); PKS, sygn. 16522/II/t.1, Gen. L. Żeligowski do Prezesa Rady Narodowej RP, Londyn 26.04.1943, s. 294; Litwa a Żmudź, DP, 15.10.1943, nr 1003, s. 3 (L. Żeligowski, Zapomniane prawdy, Londyn 1943); A. Pragier, Na manowcach federalizmu, RPWB, 1.04.1944, nr 7, s. 3; List gen. Żeligowskiego, „Rzeczpospolita”, 2.02.1945, nr 32, s. 2; J. Sosnkowska, W kręgu mitów i rzeczywistości, Warszawa 1988, s. 18; Dzienniki Czynności Prezydenta RP Władysława Raczkiewicza 1939-1947, t. 1 (1939-1942), red. J. Piotrowski, Wrocław 2004, s. 135 (Żeligowski przedstawił 4 kwietnia 1940 r. prezydentowi opracowanie o idei słowiańskiej i żądał tajnego zebrania Rady Narodowej).

47 AAN, PUWB, sygn. 220/27, Odezwa gen. Lucjana Żeligowskiego do kraju, wręczona prezesowi Rady Narodowej 31 III 1944 r. w Londynie, s. 28; Odezwa gen. Żeligowskiego do kraju, „Rzeczpospolita”, 4.08.1944, nr 2, s. 2. 
Council, Stanislaw Grabski, he demanded to read the appeal publicly and broadcast it by radio to Poland. He stated that the Slavic idea could save Poland and its place was in the Slavic alliance with the USSR. He blamed the government for not agreeing with him because they rejected the Slavic unity ${ }^{48}$. Because of the appeal he lost the title of Honorary President of the Wilanian and Lithuanian Jagiellonian Union, which he was from the Wilanów Congress in 1942 in Edinburgh. The General did not take note of this, and after the war he wanted to return to Polish Vilnius ${ }^{49}$. Polish communists used his appeal in Poland for propaganda purposes ${ }^{50}$.

Michał Kwiatkowski from the Workers' Party, since 1942, in the "Dziennik Polski", reminded the common Slavic roots of the Polish and Czech nation, their role as the front guard of the Slavs and the struggle against their statehood with Germany, which conquered the Slavic lands for ten centuries. He regretted that from Mieszko I to modern times, the Poles and the Czechs failed to cooperate because of German intrigues, although they were dependent on each other on the issue of security and independent development. He

48 AMR, PUWB, sygn. 220/vol.27, Do Prezesa Rady Narodowej 9 V 1944 r. w Londynie, p. 29; Fikcja i rzeczywistość, “Głos Warszawy”, 2.06.1944, No. 43, p. 4; Do przewodniczacego polskiej Rady Narodowej, "Rzeczpospolita", 4.08.1944, No. 2, p. 2.

49 AMR, PUWB, sygn. 220/27, Gen. L. Żeligowski do Związku Ziem Pótnocno-Wschodnich, Londyn 26.06.1944, p. 31.

50 AMR, ZPP, sygn. 216/7, Wystapienie Andrzeja Witosa, posiedzenie Plenum ZG ZPP w Moskwie, 16.07.1944, p. 23 (He said that in 1943 Żeligowski patronized the anti-Soviet Union of Poles of the North-East Territories, and in 1944 called for Slavic unity and Polish-Soviet friendship - wonderful evolution). było w przymierzu Słowian razem z ZSRR. Obarczył winą rząd za brak porozumienia z nim, bo odrzucał jedność Słowian ${ }^{48}$. Za odezwę stracił tytuł Honorowego Prezesa Związku Wilnian i Litwy Jagiellońskiej, którym był od Zjazdu Wilnian w 1942 r. w Edynburgu. Generał nie przyjął tego do wiadomości, a po wojnie chciał wracać do polskiego Wilna ${ }^{49}$. Polscy komuniści wykorzystali w Polsce propagandowo jego odezwę ${ }^{50}$.

Michał Kwiatkowski ze Stronnictwa Pracy, od 1942 r. wiceprzewodniczący Rady Narodowej, w „Dzienniku Polskim” przypomniał wspólne słowiańskie korzenie polskiego i czeskiego narodu, ich rolę przedniej straży Słowiańszczyzny i walkę od początku ich państwowości z Niemcami, które podbijały przez dziesięć wieków ziemie słowiańskie. Ubolewał, że od Mieszka I do czasów współczesnych nie udało się Polakom i Czechom współdziałać z powodu niemieckich intryg, mimo że w kwestiach bezpieczeństwa i niezależnego rozwoju byli na siebie skazani. Przestrzegał Czechów przed uczestnictwem w federacji naddunajskiej (niemiecki plan), w której przewodziłyby Austria i Węgry, a Czechosłowacja, Jugosławia i Rumunia

48 AAN, PUWB, sygn. 220/t.27, Do Prezesa Rady Narodowej 9 V 1944 r. w Londynie, s. 29; Fikcja i rzeczywistość, „Głos Warszawy”, 2.06.1944, nr 43, s. 4; Do przewodniczacego polskiej Rady Narodowej, „Rzeczpospolita”, 4.08.1944, nr 2, s. 2.

49 AAN, PUWB, sygn. 220/27, Gen. L. Żeligowski do Związku Ziem Pólnocno-Wschodnich, Londyn 26.06.1944, s. 31

50 AAN, ZPP, sygn. 216/7, Wystapienie Andrzeja Witosa, posiedzenie Plenum ZG ZPP w Moskwie, 16.07.1944, s. 23 (Mówił, że „jeszcze w 1943 r. Żeligowski patronował antysowieckiemu Związkowi Polaków Ziem Północno-Wschodnich, a w 1944 r. nawołuje do jedności słowiańskiej i przyjaźni polsko-sowieckiej - wspaniała ewolucja"). 
warned the Czechs against participating in the Danube federation (the German plan), which would be led by Austria and Hungary, while Czechoslovakia, Yugoslavia and Romania would play a secondary role. He urged them to punish Germany after the war with Poland. Poles and Czechs should take away the lands that once belonged to the Slavs, enforce war reparations, and participate in the disarmament and reduction of their industry. They had to use together the time of the weakening of Germany and Austria to increase their defense and economic potentials, and to cooperate in German affairs and European security. M. Kwiatkowski warned that the Slavs, who had disregarded the threat of Germany and had not want to unite against them, today did not exist ${ }^{51}$.

Underground civil and military authorities did not promote the Slavic idea, from which the government distanced itself. It was used by the USSR for business and imperial purposes ${ }^{52}$. The Government Delegation for Poland emphasized that the interests of the Slavic nations would secure the integration of Central Europe based on the Polish-Czechoslovak and Yugoslav-Greek agreements of January 1942. They could not be the unions of Slavs, because Lithuania, Romania and Hungary, and Greece and Albania were to join them. Moreover, both unions were

${ }^{51}$ M. Kwiatkowski, 25-lecie Czechosłowacji, DP, 28.10.1943, No. 1014, p. 3.

52 AMR, KGAK, Komenda Obszaru Lwów (KOL), sygn. 203/XV-50, Materiat szkoleniowy 1943. Zarys wykładu o propagandzie w sprawie ukraińskiej, białoruskiej i litewskiej, 1943, pp. 20-23; AMR, Rada Jedności Narodowej (RJN), sygn. 199/1, KRP, Deklaracja Porozumienia Czterech Stronnictw, Warszawa 15.08.1943, pp. 26-26a (Parlament Podziemny). odgrywałyby rolę drugorzędną. Wzywał ich, aby po wojnie z Polską dopilnowali ukarania Niemiec. Polacy i Czesi powinny odebrać im ziemie, które kiedyś należały do Słowian, egzekwować odszkodowania wojenne oraz uczestniczyć $\mathrm{w}$ rozbrajaniu i redukcji ich przemysłu. Musieli wspólnie wykorzystać czas osłabienia Niemiec i Austrii do wzrostu swoich potencjałów obronnych i gospodarczych oraz współpracować w sprawach niemieckich i bezpieczeństwa europejskiego. Michał Kwiatkowski ostrzegł, że Słowianie, którzy lekceważyli zagrożenie Niemiec i nie chcieli jednoczyć się przeciwko nim, dzisiaj już nie istnieli ${ }^{51}$.

Władze podziemne cywilne i wojskowe nie propagowały idei słowiańskiej, od której dystansował się rząd. Była wykorzystywana przez ZSRR do celów koniunkturalnych i imperialnych ${ }^{52}$. Delegatura Rządu na Kraj podkreślała, że interesy narodów słowiańskich zabezpieczyłaby integracja Europy Środkowej oparta na układach polsko-czechosłowackim i jugosłowiańsko-greckim ze stycznia 1942 r. Nie mogły być one związkami Słowian, bo miały do nich wchodzić Litwa, Rumunia i Węgry oraz Grecja i Albania, a oba ściśle ze sobą współpracować. Idea słowiańska na przestrzeni od Odry po Dniepr i od Dźwiny po Dunaj utrudniałaby Polsce realizację jej politycznego i kulturowego posłan-

${ }^{51}$ M. Kwiatkowski, 25-lecie Czechosłowacji, DP, 28.10.1943, nr 1014, s. 3.

52 AAN, KGAK, Komenda Obszaru Lwów (KOL), sygn. 203/XV-50, Materiat szkoleniowy 1943. Zarys wykładu o propagandzie w sprawie ukraińskiej, białoruskiej i litewskiej, 1943, s. 20-23; AAN, Rada Jedności Narodowej (RJN), sygn. 199/1, KRP, Deklaracja Porozumienia Czterech Stronnictw, Warszawa 15.08.1943, s. 26-26a (Parlament Podziemny). 
supposed to work closely together. The Slavic idea spreading from the Oder to the Dnieper and from Dvina to the Danube would impede Poland's realization of its political and cultural mission. In addition, Belarusians and Ukrainians also cooperated with the Germans and did not want state-owned ties with Poland ${ }^{53}$. The announcement of the post-war equality of Slavic national minorities with Poles and free national-cultural development could be regarded as the "Slavonic policy" of the Delegation and the Polish Underground Parliament. They supported their right to self-determination in Soviet areas and declared Poland's help in the development of their states ${ }^{54}$. Another aspect was the slogan of Poland's return to

53 Przemówienie gen. Sikorskiego w Perth, "Rzeczpospolita Polska", 20.08.1941, No. 11, p. 120 (organ DR); AMR, DR, Biuro Prezydialne (BP), sygn. 202/I-33, Towarzystwo Badań Zagadnień Środkowej Europy, Zagadnienie Europy Środkowej i kwestia pokoju, Wydawnictwo Badań Zagadnień Środkowej Europy, Warszawa 1943, pp. 270-319; sygn. 202/I-34, Kierownik Komisji Spraw Zagranicznych Delegatury, Uwagi o naszej polityce międzynarodowej, 22.07.1943, pp. 54-65a; Pewna drobna rocznica w stosunkach polsko-wegierskich, "Biuletyn Informacyjny” (BI), 3.12.1942, No. 47, pp. 1-2; Zebranie polsko-wegierskiego towarzystwa im. A. Mickiewicza, BI, 3.06.1943, No. 22, p. 5 (organ KGAK); AMR, RJN, sygn. 199/2, Do Narodów Świata, 8.01.1944, Komunikat o utworzeniu RJN w miejsce KRN Petnomocnika Rzadu RP na Kraj, 9.01.1944, pp. 8-9.

54 Odezwa do narodu ukraińskiego, "Rzeczpospolita Polska”, 9.08.1943, No. 14, pp. 216-217; IPMS, sygn. PRM105, Depesze gen. Sikorskiego do Komendanta Głównego AK i Delegata Rządu w sprawie terytorialnych pretensji sowieckich $i$ reakcji rzadu $R P$, Londyn 23.03.1943, p. 85, (Sikorski ordered talks with the Ukrainians on the grounds of a government declaration dated 24 February 1942); W obliczu rzeczywistości; Ukraińcy po stronie Niemiec; Osamotnienie Ukraińców w świecie, "Głos Polsko-Ukraiński”, styczeń 1944, No. 1, pp. 2-6; AMR, RJN, sygn. 199/2, Protokół posiedzenia Komisji Głównej RJN, 31.05.1944, pp. 81-82. nictwa. Do tego Białorusini i Ukraińcy współpracowali z Niemcami i nie chcieli związków państwowych z Polską ${ }^{53}$. Za „politykę słowiańską" Delegatury i Polskiego Parlamentu Podziemnego można byłoby uznać zapowiedzi powojennego równouprawnienia słowiańskich mniejszości narodowych z Polakami i swobodnego rozwoju narodowo-kulturalnego. Popierała ich prawo do samostanowienia na radzieckich obszarach i deklarowała polską pomoc w rozwoju ich państw ${ }^{54}$. Innym jej aspektem były hasła powrotu Polski na ziemie słowiańskie należące w przeszłości do Piastów. „Ziemie Zachodnie Rzeczypospolitej" ogłosiły dwa bezdyskusyjne kanony: ,ani z Niemcami ani z Rosją, silne państwo polskie w oparciu o blok środko-

53 Przemówienie gen. Sikorskiego w Perth, „Rzeczpospolita Polska”, 20.08.1941, nr 11, s. 120 (organ DR); AAN, DR, Biuro Prezydialne (BP), sygn. 202/I-33, Towarzystwo Badań Zagadnień Środkowej Europy, Zagadnienie Europy Środkowej i kwestia pokoju, Wydawnictwo Badań Zagadnień Środkowej Europy, Warszawa 1943, s. 270-319; sygn. 202/I34, Kierownik Komisji Spraw Zagranicznych Delegatury, Uwagi o naszej polityce międzynarodowej, 22.07.1943, s. 54-65a; Pewna drobna rocznica $w$ stosunkach polsko-weegierskich, „Biuletyn Informacyjny” (BI), 3.12.1942, nr 47, s. 1-2; Zebranie polsko-wegierskiego towarzystwa im. A. Mickiewicza, BI, 3.06.1943, nr 22, s. 5 (organ KGAK); AAN, RJN, sygn. 199/2, Do Narodów Świata, 8.01.1944, Komunikat o utworzeniu RJN w miejsce KRN Pełnomocnika Rzadu RP na Kraj, 9.01.1944, s. 8-9.

54 Odezwa do narodu ukraińskiego, „Rzeczpospolita Polska”, 9.08.1943, nr 14, s. 216-217; IPMS, sygn. PRM105, Depesze gen. Sikorskiego do Komendanta Głównego AK i Delegata Rząu w sprawie terytorialnych pretensji sowieckich i reakcji rzadu $R P$, Londyn 23.03.1943, s. 85 (Sikorski nakazał rozmowy z Ukraińcami na gruncie deklaracji rządu z 24 lutego 1942); W obliczu rzeczywistości; Ukraińcy po stronie Niemiec; Osamotnienie Ukraińców w świecie, „Głos Polsko-Ukraiński”, styczeń 1944, nr 1, s. 2-6; AAN, RJN, sygn. 199/2, Protokót posiedzenia Komisji Głównej RJN, 31.05.1944, s. 81-82. 
Slavic lands in the past belonging to the Piasts. The "Western Lands of the Commonwealth" proclaimed two indisputable canons: "with neither Germany nor Russia, a strong Polish state based on the Central European block", and the return to the Oder and Baltic, i.e. the Chrobry's program in the west, and in the east the Jagiellonian idea. This would not have been possible to complete without establishing the western borders of the Piasts ${ }^{55}$. In the foreground, the Home Army Headquarters gave priority to the fight for freedom and the borders of the east and the west, improved to the detriment of Germany ${ }^{56}$. Poland would maintain alliances with the Western powers and expand its military capabilities ${ }^{57}$. Then there would be time for state unions ${ }^{58}$. German and Soviet impe-

55 Przez Ziemie Zachodnie ku Bałtykowi i Odrze, "Ziemie Zachodnie Rzeczypospolitej" (ZZR), listopad-grudzień 1943, No. 6, pp. 1-4; Ziemie Powracajace integralnie związane z Polska, ZZR, kwiecień-maj 1944, No. 3, pp. 1-2; (Organ DR - ZZR wysunęły ideę Ziemie Nadodrzańskie - Ziemie Macierzyste, czyli odzyskania ziem należaccych za Mieszka I $i$ Bolesława Chrobrego do Polski, [in:] Dogmat życia polskiego, ZZR, listopad 1942, No. 1, pp. 2-3; Na zawsze Ślask Opolski wróci do ojczyzny, ZZR, marzec-kwiecień 1943, No. 2, pp. 8-11; Prusy Wschodnie - przyszły bastion Polski, ZZR, czerwiec 1944, No. 4, pp. 4-5).

56 IPMS, sygn. PRM.L.17, Grot, Pan Główny Delegat Rzadu w Kraju, Komendant Sił Zbrojnych w Kraju, No. 55, 15.12.1941, pp. 5-9; AMR, KGAK, BIP, sygn. 203/VII-67, Problem przyszłych granic Polski. Materiał dla prelegentów propagandowych, 1943, pp. 12-21.

57 O należyta perspektywę, "Wiadomości Polskie”, 23.09.1942, No. 17, p. 269 (KGAK).

58 Układ polsko-czeski, BI, 29.01.1942, No. 4, pp. 3-4; Konfederacja państw Europy Środkowej, "Wiadomości Polskie", 15.07.1942, No. 69-70, p. 154; AMR, KGAK, BIP, sygn. 203/VII-1, KSZ Wolski, Wytyczne propagandowe No. 1/44, Warszawa styczeń 1944, p. 5; G. Mazur, Biuro Informacji i Propagandy SZP-ZWZ-AK 1939-1945, Warszawa 1987, pp. 290-301. woeuropejski” oraz powrót nad Odrę i Bałtyk, czyli na zachodzie program Chrobrego, a na wschodzie idea jagiellońska. Tej nie dałoby się zrealizować bez zajęcia zachodnich granic Piastów $w^{55}$. Na pierwszym planie Komenda Główna Armii Krajowej stawiała walkę o wolność oraz granice ryską na wschodzie i zachodnią, poprawioną kosztem Niemiec ${ }^{56}$. Polska utrzymałaby sojusze z zachodnimi mocarstwami i powiększyła swój potencjał militarny ${ }^{57}$. Potem przyszedłby czas na związki państwowe $^{58}$. Niemiecki i radziecki imperializm uświadomił państwom od Skandynawii po Bałkany geopolityczne znaczenie niepodległej Polski ${ }^{59}$. Powojenny blok

55 Przez Ziemie Zachodnie ku Bałtykowi i Odrze, „Ziemie Zachodnie Rzeczypospolitej” (ZZR), listopad-grudzień 1943, nr 6, s. 1-4; Ziemie Powracajace integralnie zwiąane $z$ Polska, ZZR, kwiecień-maj 1944, nr 3, s. 1-2; (Organ DR - ZZR wysunęły ideę Ziemie Nadodrzańskie - Ziemie Macierzyste, czyli odzyskania ziem należących za Mieszka I i Bolesława Chrobrego do Polski, [w:] Dogmat życia polskiego, ZZR, listopad 1942, nr 1, s. 2-3; Na zawsze Ślask Opolski wróci do ojczyzny, ZZR, marzec-kwiecień 1943, nr 2, s. 8-11; Prusy Wschodnie - przyszły bastion Polski, ZZR, czerwiec 1944, nr 4, s. 4-5).

56 IPMS, sygn. PRM.L.17, Grot, Pan Główny Delegat Rzadu w Kraju, Komendant Sił Zbrojnych w Kraju, nr 55, 15.12.1941, s. 5-9; AAN, KGAK, BIP, sygn. 203/VII-67, Problem przyszłych granic Polski. Materiał dla prelegentów propagandowych, 1943, s. 12-21.

57 O należyta perspektywę, „Wiadomości Polskie”, 23.09.1942, nr 17, s. 269 (KGAK).

58 Układ polsko-czeski, BI, 29.01.1942, nr 4, s. 3-4; Konfederacja państw Europy Środkowej, „Wiadomości Polskie”, 15.07.1942, nr 69-70, s. 154; AAN, KGAK, BIP, sygn. 203/VII-1, KSZ Wolski, Wytyczne propagandowe $n r$ 1/44, Warszawa styczeń 1944 , s. 5; G. Mazur, Biuro Informacji i Propagandy SZP-ZWZ-AK 1939-1945, Warszawa 1987, s. 290-301.

59 Postawa ZSRR, BI, 30.08.1940, s. 3-4; Pakt Trzech, BI, 4.10.1940, s. 2-3; Mołotow w Berlinie, BI, 21.11.1940, s. 2-3; AAN, KGAK, BIP, sygn. 203/ VII-67, Problem przyszłych granic Polski. Materiał dla prelegentów propagandowych, s. 11 . 
rialism made the states from the Scandinavian countries to the Balkans aware of the geopolitical significance of independent Poland ${ }^{59}$. The postwar block defense with Poland guaranteed their independence and security. During the dissolution of the USSR it was necessary to include Ukraine and Belarus into the block. Loyal national minorities would have civil rights to defend the Polish state ${ }^{60}$.

The Polish democratic left believed that the German Pan-Europe and the Soviet Pan-Slavdom masked imperialism against weaker states and nations ${ }^{61}$. Cooperating with Hitler and resorting to propaganda to Great Russian nationalism, Stalin betrayed the revolution. At that time, he annexed a number of neighboring nations, and his occupation was no different from that of Germany ${ }^{62}$. After German ag-

59 Postawa ZSRR, BI, 30.08.1940, pp. 3-4; Pakt Trzech, BI, 4.10.1940, pp. 2-3; Mołotow w Berlinie, BI, 21.11.1940, pp. 2-3; AMR, KGAK, BIP, sygn. 203/ VII-67, Problem przyszłych granic Polski. Materiat dla prelegentów propagandowych, p. 11.

60 Obronność przyszłej Polski, "Insurekcja”, wrzesień-październik 1941, No. 9-10, [in:] Wojsko ogłasza program, "Myśl", styczeń 1942, No. 1, pp. 3-6; AMR, KGAK, KOL, sygn. 203/XV-45, Ocena zagadnienia ukraińskiego, 1943, pp. 30-36; Ogólny zarys projektu Odbudowy Ziemi Czerwieńskiej i normowanie jej stosunków wewnętrznych niezbędnych po działaniach wojennych i rządach okupacyjnych w latach 19391943, 1943, pp. 37-49; BIP, sygn. 203/VII-1, KSZ Wolski, Wytyczne propagandowe No. 1/44, Warszawa styczeń 1944 , p. 4.

61 Idea federacji, "Gwardia”, luty 1942, No. 21, p. 48 (grupa "Gwardia"); Polska Partia Socjalistyczna: Idea federacji (Londyn 1942), [in:] Polskie wizje Europy w XIX i XX wieku, edit. P.O. Loew, Wrocław 2004, pp. 148-151; K. Dunin-Wąsowicz, Polski ruch socjalistyczny 1939-1945, Warszawa 1993, p. 246; Polska Partia Socjalistyczna w latach wojny i okupacji 1939-1945. Aneks, edit. W. Czarnecki, Warszawa 1995, p. 18.

62 Polska nie będzie byle jaka, "WRN", 1-14.12.1940, No. 28, pp. 130-133; Na imperialistycz- obronny z Polską gwarantował im niezależność i bezpieczeństwo. Przy rozpadzie ZSRR należało do niego włączyć Ukrainę i Białoruś. Lojalne mniejszości narodowe posiadałyby prawa obywatelskie, aby broniły państwa polskiego ${ }^{60}$.

Polska lewica demokratyczna uważała, że niemiecka Paneuropa i radziecka Pan-Słowiańszczyzna maskowały imperializm wobec słabszych państw i narodów ${ }^{61}$. Współpracą z Hitlerem i odwoływaniem się w propagandzie do wielkorosyjskiego nacjonalizmu Stalin zdradził rewolucję. W tym czasie anektował wiele sąsiednich narodów, a jego okupacja nie różniła się od niemieckiej ${ }^{62}$. Po niemieckiej agresji w 1941 r. ZSRR ogłosił się obrońcą Europy i narodów słowiańskich wobec Niemiec, ale nie wyrzekł się imperialistycznych zdobyczy ${ }^{63}$. Upadek totalitar-

60 Obronność przyszłej Polski, „Insurekcja”, wrzesień-październik 1941, nr 9-10, [w:] Wojsko ogłasza program, „Myśl”, styczeń 1942, nr 1, s. 3-6; AAN, KGAK, KOL, sygn. 203/XV-45, Ocena zagadnienia ukraińskiego, 1943, s. 30-36; Ogólny zarys projektu Odbudowy Ziemi Czerwieńskiej i normowanie jej stosunków wewnętrznych niezbędnych po działaniach wojennych $i$ rzadach okupacyjnych $w$ latach 1939-1943, 1943, s. 37-49; BIP, sygn. 203/VII-1, KSZ Wolski, Wytyczne propagandowe nr 1/44, Warszawa styczeń 1944, s. 4.

61 Idea federacji, „Gwardia”, luty 1942, nr 21, s. 48 (grupa „Gwardia”); Polska Partia Socjalistyczna: Idea federacji (Londyn 1942), [w:] Polskie wizje Europy w XIX i XX wieku, red. P. O. Loew, Wrocław 2004, s. 148-151; K. Dunin-Wąsowicz, Polski ruch socjalistyczny 1939-1945, Warszawa 1993, s. 246; Polska Partia Socjalistyczna w latach wojny i okupacji 1939-1945. Aneks, red. W. Czarnecki, Warszawa 1995 , s. 18.

62 Polska nie będzie byle jaka, „WRN”, 1-14.12.1940, nr 28, s. 130-133; Na imperialistycznym szlaku, „WRN”, 15-31.12.1940, nr 29, s. 144 (PPS-Wolność Równość Niepodległość).

63 Wojna niemiecko-rosyjska a wojna, „WRN”, 15-28.06.1941, nr 42, s. 83-84; Stalin mówi i przemil- 
gression in 1941, the USSR declared itself a defender of Europe and Slavic peoples against Germany but did not renounce the imperialist conquests ${ }^{63}$. The collapse of totalitarian Germany and the USSR afforded the laboring masses for the decentralized, democratic and socialist "Union of the Free Peoples of Europe" on the principle of "the free with the free, the equal with the equal"64. Democratic and socialist Russia could be part of $\mathrm{it}^{65}$. International working-class solidarity would free Europe and the world from nationalist wars and social oppression ${ }^{66}$. Central European nations were not free to operate in a "federation with the terrorist powers of Germany or Russia" ${ }^{\prime \prime 7}$. The Polish-Czechoslovak alliance would be the basis of their federation on the basis of Western humanitarianism

nym szlaku, "WRN”, 15-31.12.1940, No. 29, p. 144 (PPS-Wolność Równość Niepodległość).

63 Wojna niemiecko-rosyjska a wojna, "WRN", 15-28.06.1941, No. 42, pp. 83-84; Stalin mówi i przemilcza; W przeddzień wojny; Trudno uwierzyć, “WRN", 29.06-12.07.1941, No. 43, pp. 91, 93.

64 AMR, WRN, sygn. 205/1, Uchwała zasadnicza II konferencji mas pracujacych, Warszawa 1940, p. 24; Manifest Do Ludów Świata, luty 1941, pp. 1213a; Odezwa, Do Ludu Pracujacego Miast i Wsi, Warszawa 24.06.1941, pp. 14-14a; Na drodze ku nowej Europie, "WRN", 10-20.09.1940, No. 26, p. 115; sygn. 1174/2, Noa Europa, "WRN”, 15-29.02.1941, No. 33, pp. 24-25; Rocznice i przyszłość; Rewolucje wyzwoleńcze, "Gwardia”, listopad 1941, No. 18, pp. 30, 34; J. Juchnowski, Plany federacyjne polskich socjalistów w Katach II wojny światowej, [in:] Europejskie doktryny porozumienia i współpracy gospodarczej w XX wie$k u$, edit. K. Fiedor, vol. 1, Wrocław 1987, pp. 91-116.

65 Idea federacji, a problem mniejszości narodowych Polski, "Gwardia”, marzec 1942, No. 22, p. 139.

66 Dziesięć lat wojny; Uwagi o socjalizmie i narodzie, "Młodzież Socjalistyczna", luty 1944, No. 2, pp. 2, 9; Najpilniejsze zadania oświata, "Młodzież Socjalistyczna”, kwiecień-maj 1944, No. 4, pp. 8-10 (grupa „Światło").

67 Między Niemcami a Rosja, "Wolność", marzec 1942, p. 65 (PPS-WRN). nych Niemiec i ZSRR dawał możliwość masom pracującym powołania zdecentralizowanego, demokratycznego i socjalistycznego „Związku Wolnych Ludów Europy” na zasadzie „wolni z wolnymi równi z równymi”64. Demokratyczna i socjalistyczna Rosja mogła być jego częścią ${ }^{65}$. Międzynarodowa solidarność klasy robotniczej uwolniłaby Europę i świat od nacjonalistycznych wojen i społecznego uci$\mathrm{sku}^{66}$. Narody Europy Środkowej nie mogły swobodnie funkcjonować $\mathrm{w}$,Związku federacyjnym $\mathrm{z}$ terrorystycznymi potęgami Niemiec czy Rosji”"67. Związek polsko-czechosłowacki byłby podstawą ich federacji, opierając się na zachodnim humanitaryzmie i polskiej tradycji unii narodów $w^{68}$. Ich ścisłe połączenie było gwarancją skutecz-

cza; W przeddzień wojny; Trudno uwierzyć, „WRN”, 29.06-12.07.1941, nr 43, s. 91, 93.

64 AAN, WRN, sygn. 205/1, Uchwała zasadnicza II konferencji mas pracujacych, Warszawa 1940, s. 24; Manifest Do Ludów Świata, luty 1941, s. 12-13a; Odezwa, Do Ludu Pracujacego Miast $i$ Wsi, Warszawa 24.06.1941, s. 14-14a; Na drodze ku nowej Europie, „WRN”, 10-20.09.1940, nr 26, s. 115; sygn. 1174/2, Nowa Europa, „WRN”, 15-29.02.1941, nr 33, s. 2425; Rocznice i przyszłość; Rewolucje wyzwoleńcze, „Gwardia”, listopad 1941, nr 18, s. 30, 34; J. Juchnowski, Plany federacyjne polskich socjalistów w Katach II wojny światowej, [w:] Europejskie doktryny porozumienia i współpracy gospodarczej $w$ XX wieku, red. K. Fiedor, t. 1, Wrocław 1987, s. 91-116.

65 Idea federacji, a problem mniejszości narodowych Polski, „Gwardia”, marzec 1942, nr 22, s. 139.

66 Dziesięć lat wojny; Uwagi o socjalizmie i narodzie, „Młodzież Socjalistyczna”, luty 1944, nr 2, s. 2, 9; Najpilniejsze zadania oświata, „Młodzież Socjalistyczna”, kwiecień-maj 1944, nr 4, s. 8-10 (grupa „Światło”).

67 Między Niemcami a Rosją, „Wolność”, marzec 1942, s. 65 (PPS-WRN).

68 AAN, WRN, sygn. 205/1, Program Polski Ludowej, Warszawa 1941, s. 3a, 5a; Odezwa, O czym w dniu 1 września każdy Polak winien pomyśleć, Warszawa 1941, s. 33-34a; Jaka ma być i jaka będzie Nowa Polska. Kraj opracował program Polski Ludowej, RPWB, 1.08.1942, nr 15, s. 1-2, 4. 
and the Polish tradition of the union of nations ${ }^{68}$. Their close uniting was a guarantee of effective opposition to imperialism from the East and the West ${ }^{69}$. In contrast, the group "Płomienie" perceived the Polish-Czechoslovak confederation as a "Slavonic community"70. In it the Poles would see the greatness and power of their own and their nations. This historically significant act moved the center of strength from "Berlin to Warsaw and Prague, great centers of life and Slavic culture"71. Poland, living in the heart of the Slavic nations, would regulate relations in Central Europe and maintain its independence from Germany and the USSR ${ }^{72}$. The left rejected the imperial and Slavophile visions of the international integration of Polish groups towards neighboring nations, which would combine the power of the state and nations within a Slavic empire ${ }^{73}$.

68 AMR, WRN, sygn. 205/1, Program Polski Ludowej, Warszawa 1941, pp. 3a, 5a; Odezwa, O czym $w$ dniu 1 września każdy Polak winien pomyśleć, Warszawa 1941, pp. 33-34a; Jaka ma być i jaka będzie Nowa Polska. Kraj opracował program Polski Ludowej, RPWB, 1.08.1942, No. 15, pp. 1-2, 4.

69 Konfederacja polsko-czechosłowacka, "WRN", 25.01-7.02.1942, No. 3, p. 76.

70 W obliczu konfederacji polsko-czeskiej, "Płomienie", luty-marzec 1942, p. 43 (grupa "Płomienie").

71 Rola dziejowa Polski, "Płomienie", styczeń 1942, No. 1, p. 47.

72 Ogólne podstawy organizacyjne naszego państwa, "Płomienie", styczeń 1942, No. 1, p. 60.

73 Polski imperializm, "Gwardia", styczeń 1942, No. 20, p. 72; Zakłamane manewry reakcji, „WRN”, 1-14.02.1941, No. 32, pp. 17-21; Marzenia polskich faszystów, "WRN", 20.04-3.05.1941, No. 38, pp. 6970; Głos Polski Walczacej, "WRN", 18-31.05.1941, No. 40, p. 76; Wystąpienie słowianofilskie, "WRN", 5-18.10.1941, No. 76, p. 117; Z. Żuławski, Z pamiętnika, [in:] Polska Partia Socjalistyczna w latach wojny i okupacji 1939-1945. Księga Wspomnień, vol. 2, edit. W. Czarnecki, Warszawa 1995, pp. 693-694 (PPS-WRN). nego przeciwstawienia się imperializmowi ze Wschodu i Zachodu ${ }^{69}$. Natomiast grupa „Płomienie” postrzegała konfederację polsko-czechosłowacką jako „wspólnotę słowiańską"70. W niej Polacy zobaczyliby wielkość i siłę własną i pobratymczych narodów. Ten historycznie doniosły akt przesuwał ośrodek sily z „Berlina do Warszawy i Pragi, wielkich centrów życia i kultury słowiańskiej" ${ }^{\prime \prime 1}$. Polska, żyjąca w sercu narodów słowiańskich, regulowałaby stosunki w Europie Środkowej i utrzymywała niezależność wobec Niemiec i ZSRR ${ }^{72}$. Lewica odrzucała imperialne i słowianofilskie wizje międzynarodowej integracji polskich grup wobec sąsiednich narodów, które wiązałyby siłą państwa i narody w ramach jakiegoś imperium słowiańskiego ${ }^{73}$.

ZSRR był stalinowską dyktaturą, uciskającą masy pracujące i radzieckie narody. Komintern stał się narzędziem jego imperializmu. Partia bolszewicka przekształciła się w biurokrację państwową ${ }^{74}$. Polska lewica rewolucyjna uważała, że po zdemo-

69 Konfederacja polsko-czechosłowacka, „WRN”, 25.01-7.02.1942, nr 3, s. 76.

70 W obliczu konfederacji polsko-czeskiej, „Płomienie”, luty-marzec 1942, s. 43 (grupa „Płomienie”).

71 Rola dziejowa Polski, „Płomienie”, styczeń 1942, nr 1, s. 47.

72 Ogólne podstawy organizacyjne naszego państwa, „Płomienie”, styczeń 1942, nr 1, s. 60.

73 Polski imperializm, „Gwardia”, styczeń 1942, nr 20, s. 72; Zakłamane manewry reakcji, "WRN”, 1-14.02.1941, nr 32, s. 17-21; Marzenia polskich faszystów, „WRN”, 20.04-3.05.1941, nr 38, s. 69-70; Głos Polski Walczacej, „WRN”, 18-31.05.1941, nr 40, s. 76; Wystapienie słowianofilskie, „WRN”, 5-18.10.1941, nr 76, s. 117; Z. Żuławski, Z pamiętnika, [w:] Polska Partia Socjalistyczna $w$ latach wojny $i$ okupacji 1939-1945. Księga Wspomnień, t. 2, red. W. Czarnecki, Warszawa 1995, s. 693-694 (PPS-WRN).

74 Nasz stosunek do Rosji, „Rzeczpospolita”, styczeń 1943, nr 1, s. 3-9 (Polska Ludowa Akcja Niepodległościowa). 
The USSR was a Stalinist dictatorship, oppressing working masses and Soviet nations. The Comintern became a tool of its imperialism. The Bolshevik party turned into a state bureaucracy ${ }^{74}$. The Polish revolutionary left believed that, after democratization and decentralization, it could be part of the classless, socialist Europe of the Free Nations ${ }^{75}$. It rejected the Soviet doctrine of the unity of the Slav nations against the Germans. It was in favor of the organization of the world, linking "the family of the Slavic, German, Romanian and all other nations"76. To the hegemony of the powers it placed in the opposition the vision of a democratic European Socialist Federation, based on the principle of self-determination and equality of nations, with guarantees of rights for national minorities $^{77}$. Socialist and democratic Poland in the union with Czechoslovakia would join the Central European states ${ }^{78}$. It opposed

74 Nasz stosunek do Rosji, "Rzeczpospolita”, styczeń 1943, No. 1, pp. 3-9 (Polska Ludowa Akcja Niepodległościowa).

75 Perspektywy, "Barykada Wolności” (BW), 17.10.1940, No. 21, p. 18; O co toczy sie wojna, BW, 1.12.1940, No. 23, p. 38: Krok naprzód, BW, 11.08.1941, No. 59, p. 225; Polsko-sowiecka deklaracja przyjaźni, BW, 14.12.1941, No. 77, p. 291 (Polscy Socjaliści, later Robotnicza Partia Polskich Socjalistów).

76 Zjednoczone Stany Europy (excerpt from a book Socjologia $w$ goraczce), BW, 11.08.1941, No. 59, p. 227; Stany Zjednoczone Europy i doświadczenia Ligi Narodów, BW, 24.08.1941, No. 61, p. 193; Polska i Sowiety, "Robotnik", 8.03.1943, No. 106, pp. 2-3; Po oświadczeniu TASS, "Robotnik", 15.03.1943, No. 107, pp. 1-2 (RPPS).

77 Stany Zjednoczone Europy i terytoria mieszane narodowo, BW, 7.09.1941, No. 63, p. 220; RPPS, sygn. 196/1, Program Robotniczej Partii Polskich Socjalistów, 1943, pp. 4a-5; Trzy koncepcje polityczne, "Robotnik", 1.03.1943, No. 105, p. 2; Po zjeździe, "Robotnik", 19.04.1943, No. 112, p. 2.

78 Stany Zjednoczone Europy Socjalistycznej, BW, sierpień 1940, No. 11, p. 7; Unia polsko-czeska, kratyzowaniu i zdecentralizowaniu mógłby być częścią bezklasowej, socjalistycznej Europy Wolnych Ludów ${ }^{75}$. Odrzucała radziecką doktrynę jedności narodów słowiańskich przeciwko Niemcom. Była za organizacją świata łączącą „, rodzinę narodów słowiańskich, germańskich, romańskich i wszelkich innych"76. Hegemonii mocarstw przeciwstawiała wizję demokratycznej Europejskiej Federacji Socjalistycznej, opartej na zasadzie samookreślenia i równości narodów, z gwarancjami praw dla mniejszości narodowych ${ }^{77}$. Socjalistyczna i demokratyczna Polska w unii z Czechosłowacją łączyłaby państwa środkowoeuropejskie ${ }^{78}$. Sprzeciwiała się wykorzystywaniu w kraju idei federacyjnej i słowiańskiej do budowania mocarstwowej Polski czy Imperium Słowiańskiego w Europie Środkowej ${ }^{79}$.

75 Perspektywy, „Barykada Wolności” (BW), 17.10.1940, nr 21, s. 18; O co toczy się wojna, BW, 1.12.1940, nr 23, s. 38: Krok naprzód, BW, 11.08.1941, nr 59, s. 225; Polsko-sowiecka deklaracja przyjaźni, BW, 14.12.1941, nr 77, s. 291 (Polscy Socjaliści, potem Robotnicza Partia Polskich Socjalistów).

76 Zjednoczone Stany Europy (fragment książki Socjologia w goraczce), BW, 11.08.1941, nr 59, s. 227; Stany Zjednoczone Europy i doświadczenia Ligi Narodów, BW, 24.08.1941, nr 61, s. 193; Polska i Sowiety, „Robotnik”, 8.03.1943, nr 106, s. 2-3; Po oświadczeniu TASS, „Robotnik”, 15.03.1943, nr 107, s. 1-2 (RPPS).

77 Stany Zjednoczone Europy i terytoria mieszane narodowo, BW, 7.09.1941, nr 63, s. 220; RPPS, sygn. 196/1, Program Robotniczej Partii Polskich Socjalistów, 1943, s. 4a-5; Trzy koncepcje polityczne, „Robotnik”, 1.03.1943, nr 105, s. 2; Po zjeździe, „Robotnik", 19.04.1943, nr 112, s. 2.

78 Stany Zjednoczone Europy Socjalistycznej, BW, sierpień 1940, nr 11, s. 7; Unia polsko-czeska, BW, 2.03.1941, nr 36, s. 52; DR, DIP, sygn. 202/III61, Problem federacji, „Uwagi Polityczne”, 4.12.1941, nr 24, s. 11-11a (RPPS).

79 AAN, ZPKP, sygn. 42/3, Hitleryzm w kontu$s z u, \mathrm{BW}, 15.02 .1942, \mathrm{nr} 82$, s. 13-15. 
the use of federal and Slavic ideas in Poland to build the great Poland or the Slavonic Empire in Central Europe ${ }^{79}$.

The Syndicalists warned that the nations lying between Germany and the USSR might have gotten into the Germanic or Soviet mass, or try to establish a Central European federation. In the face of their imperialism, "the two western bastions of the Slavs", Poland and Czechoslovakia created a state union between 1940 and $1942^{80}$. It was the beginning of a bloc of countries on the line of civilizational development of Europe, leading to the postwar United States of Central Europe. After regaining independence, Lithuania, Belarus and Ukraine would join them ${ }^{81}$. It would combine equality, fraternity, solidarity, equal rights and close cooperation with the Yugoslav-Greek-Bulgarian Union $^{82}$. The USSR did not abandon totalitarianism, imperialism and revolution irrespective of war alliances ${ }^{83}$. It left the Slavic

BW, 2.03.1941, No. 36, p. 52; DR, DIP, sygn. 202/III61, Problem federacji, "Uwagi Polityczne", 4.12.1941, No. 24, pp. 11-11a (RPPS).

79 AMR, ZPKP, sygn. 42/3, Hitleryzm w kontu$s z u$, BW, 15.02.1942, No. 82, pp. 13-15.

80 Konfederacja polsko-czechosłowacka, "Myśl", luty 1942, No. 3, p. 1 (Związek Syndykalistów Polskich).

81 IPMS, sygn. PRM45B, Kujmy broń, pp. 46-48; Co zrobimy z Ukraina?, "Myśl”, listopad 1941, No. 5, pp. 1-4; Zagadnienie Ukrainy, „Sprawa”, 1941, No. 18, [in:] „Myśl”, listopad 1941, No. 5, p. 11; Nowy Lad, “Myśl-PM", październik 1942, No. 11, p. 2 (ZSP).

821939 - IX - 1942, "Walka Ludu" (WL), 1.09 .1942 , No. 14, pp. 1-2, (Odezwa na czwarty rok wojny); O federacji ludów Europy, WL, 12.09.1942, No. 15, pp. 2-3; Ku federacji, WL, 15.11.1942, No. 16, pp. 2-4 (Syndykalistyczna Organizacja "Wolność").

83 Znotatnika propagandzisty, "Myśl”, 1.08.1941, No. 1, pp. 14-15; Propaganda milczenia, "Myśl-PM”, sierpień 1942, No. 10, pp. 4-5; Kto nam rozkazuje, “Myśl”, kwiecień 1942, No. 5, p. 1; Ostrzeżenie, "Myśl-
Syndykaliści ostrzegali, że narody leżące między Niemcami i ZSRR mogły wsiąknąć w masę germańską lub radziecką albo zdobyć się na powołanie federacji środkowoeuropejskiej. Wobec ich imperializmu „dwa zachodnie bastiony Słowiańszczyzny" Polska i Czechosłowacja zawarły w latach 1940-1942 unię państwową ${ }^{80}$. Była początkiem bloku państw leżących na linii cywilizacyjnego rozwoju Europy, prowadzącego do powojennych Stanów Zjednoczonych Europy Środkowej. Po odzyskaniu niepodległości przystąpiłyby do nich Litwa, Białoruś i Ukraina ${ }^{81}$. Łączyłaby je równość, braterstwo, solidarność, równe prawa i ścisła współpraca $\mathrm{z}$ unią jugosłowiańsko-grecko-bułgarską ${ }^{82}$. ZSRR nie porzucił totalitaryzmu, imperializmu i rewolucji niezależnie od wojennych sojuszy ${ }^{83}$. Zostawił słowiańskie narody polski, czeski, słowacki i jugosłowiański na pastwę Niemiec, łamiąc zawarte z nimi układy ${ }^{84}$. Po

80 Konfederacja polsko-czechosłowacka, „Myśl”, luty 1942, nr 3, s. 1 (Związek Syndykalistów Polskich).

81 IPMS, sygn. PRM45B, Kujmy broń, s. 4648; Co zrobimy z Ukrainą?, „Myśl”, listopad 1941, nr 5, s. 1-4; Zagadnienie Ukrainy, „Sprawa”, 1941, nr 18, [w:] „Myśl”, listopad 1941, nr 5, s. 11; Nowy Ład, „Myśl-PM”, październik 1942, nr 11, s. 2 (ZSP).

821939 - IX - 1942, „Walka Ludu” (WL), 1.09.1942, nr 14, s. 1-2 (Odezwa na czwarty rok wojny); O federacji ludów Europy, WL, 12.09.1942, nr 15, s. 2-3; Ku federacji, WL, 15.11.1942, nr 16, s. 2-4 (Syndykalistyczna Organizacja „Wolność”).

83 Z notatnika propagandzisty, „Myśl”, 1.08.1941, nr 1, s. 14-15; Propaganda milczenia, „Myśl-PM”, sierpień 1942, nr 10, s. 4-5; Kto nam rozkazuje, „Myśl”, kwiecień 1942, nr 5, s. 1; Ostrzeżenie, „Myśl-PM”, maj 1942, nr 6, s. 8; Walka o dusze polskie, „Myśl-PM”, lipiec 1942, nr 8, s. 7-8; Szkodnicy i zdrajcy, „Sprawa”, 30.01.1942, s. 104; Z żcia kraju. Polska Partia Robotnicza, „Sprawa”, 12.02.1942, s. 104 (ZSP).

${ }^{84}$ Lęk przed Federacja Wolnych Ludów, WL, 15.01.1943, nr 2, s. 2-5 (SO „Wolność). 
Polish, Czech, Slovakian and Yugoslavian nations to emboldened Germany, breaking the agreements with them ${ }^{84}$. After German aggression, it used national and Slavic slogans to fight the Germans and create postSlavic unity ${ }^{85}$. This was to facilitate the Red Army's march into Europe ${ }^{86}$. National and Slavonic slogans of internationalist communist parties in Central Europe resulted from their lack of social support ${ }^{87}$. The USSR could become part of united Europe after its evolution into a democratic state of workers and peasants with the right to self-determination of their nations ${ }^{88}$. Federal and Slavic ideas could not subordinate Central European countries to Poland ${ }^{89}$.

-PM", maj 1942, No. 6, p. 8; Walka o dusze polskie, „Myśl-PM”, lipiec 1942, No. 8, pp. 7-8; Szkodnicy i zdrajcy, „Sprawa”, 30.01.1942, p. 104; Z życia kraju. Polska Partia Robotnicza, "Sprawa", 12.02.1942, p. 104 (ZSP).

84 Lęk przed Federacja Wolnych Ludów, WL, 15.01.1943, No. 2, pp. 2-5 (SO "Wolność").

${ }^{85}$ Rozmowa zPPR-owcem, WL, 10.11.1942, No. 11, p. 4 ("Slavism is the union, it is a federation of the free men with the free men, equal with equal, and not the annexation and rape "); Lęk przed Federacją Wolnych Ludów, WL, 15.01.1943, No. 2, pp. 2-5.

${ }^{86}$ PPR, "Czyn", 4.09.1943, No. 7, p. 6 (ZSP).

87 III Komitet Międzynarodowy, "Czyn", 9.07.1943, No. 3, p. 4.

${ }^{88}$ Smętny październik w Moskwie - Rosja się nie rusza: celowa polityka czy rozterki?, "Droga Wolności", listopad 1940, No. 4, p. 4; Jedna przegrana rewolucja, "Droga Wolności", marzec 1941, No. 2, p. 2; Wyzwolenie Ludów, WL, 1.04.1942, No. 4, pp. 2-3; Prawda $w$ oczy, WL, 26.09.1942, No. 16, p. 2 (SO "Wolność").

${ }^{89}$ O przyszła Polske, WL, 8.03.1942, No. 3, pp. 2-5; Jesteśmy patriotami, WL, 10.05.1942, No. 11, pp. 1-2 (SO “Wolność"); O cześć wam panowie magnaci, "Myśl-PM", sierpień 1942, No. 10, p. 7; Ojczyzna i klasa, "Czyn", 11.12.1943, No. 9, p. 1 (ZSP); S. Ciesielski, Koncepcje polityczne Zwiazku Syndykalistów Polskich w latach drugiej wojny światowej, [in:] Wrocławskie Studia z Dziejów Najnowszych, edit. W. Wrzesiński, Wrocław 1992 (AUW No. 1247, Historia, vol. 90), p. 269. niemieckiej agresji wykorzystywał hasła narodowe i słowiańskie do walki z Niemcami i stworzenia powojennej jedności słowiańskiej ${ }^{85}$. Miało to ułatwić marsz Armii Czerwonej w głąb Europy ${ }^{86}$. Hasła narodowe i słowiańskie internacjonalistycznych partii komunistycznych w Europie Środkowej wynikały $\mathrm{z}$ braku ich społecznego poparcia ${ }^{87}$. ZSRR mógł być częścią zjednoczonej Europy po ewolucji w demokratyczne państwo robotników i chłopów $\mathrm{z}$ prawem do samostanowienia jego narodów $^{88}$. Idea federacyjna i słowiańska nie mogły podporządkowywać państw środkowoeuropejskich Polsce ${ }^{89}$.

Ugrupowania centrowo-lewicowe uważały narodową i słowiańską propagandę radziecką, powstanie PPR i radzieckie desanty w Polsce za imperialną politykę ZSRR wobec Europy Środkowej ${ }^{90}$.

85 Rozmowa z PPR-owcem, WL, 10.11.1942, nr 11, s. 4 („słowiańskość to unia, to federacja wolnych $\mathrm{z}$ wolnymi, równych $\mathrm{z}$ równymi a nie zabór i gwałt"); Lęk przed Federacją Wolnych Ludów, WL, 15.01.1943, nr 2, s. 2-5.

86 PPR, „Czyn”, 4.09.1943, nr 7, s. 6 (ZSP).

87 III Komitet Międzynarodowy, „Czyn”, 9.07.1943, nr 3, s. 4.

88 Smętny październik w Moskwie - Rosja się nie rusza: celowa polityka czy rozterki?, „Droga Wolności", listopad 1940, nr 4, s. 4; Jedna przegrana rewolucja, „Droga Wolności”, marzec 1941, nr 2, s. 2; Wyzwolenie Ludów, WL, 1.04.1942, nr 4, s. 2-3; Prawda w oczy, WL, 26.09.1942, nr 16, s. 2 (SO „Wolność”).

89 O przyszłą Polskę, WL, 8.03.1942, nr 3, s. 2-5; Jesteśmy patriotami, WL, 10.05.1942, nr 11, s. 1-2 (SO „Wolność”); O cześć wam panowie magnaci, „Myśl-PM”, sierpień 1942, nr 10, s. 7; Ojczyzna i klasa, „Czyn”, 11.12.1943, nr 9, s. 1 (ZSP); S. Ciesielski, Koncepcje polityczne Związku Syndykalistów Polskich w latach drugiej wojny światowej, [w:] Wrocławskie Studia z Dziejów Najnowszych, red. W. Wrzesiński, Wrocław 1992 (AUW No. 1274, Historia, t. 90), s. 269.

90 Dyskusja, która mogła mieć miejsce..., „Polska Żyje” (PŻ), 16.10.1941, nr 93, s. 1-3; Niebezpieczeństwo komunizmu, PŻ, 18.07.1942, nr 103, s. 1; 
Centre-left groups considered national and Slavic Soviet propaganda, the rise of the Polish Workers' Party (PPR) and Soviet descents in Poland as the imperial policy of the USSR against Central Europe ${ }^{90}$. The catastrophe of small and mediumsized states showed that they had to create together a center of force against imperial powers from the Baltic to the Mediterranean Sea ${ }^{91}$. The Polish-Czechoslovak confederation implemented the idea of Slavonic solidarity, open to the non-Slavic nations of Central Europe and the Slavic ones in the USSR ${ }^{92}$. It was the beginning of the "new era of thriving of the Slavic states", which was "the cornerstone of the finally realized large block of nations inhabiting the Baltic-Black Sea Intermarium"93. It was planned as a defense against the German threat and a balance factor between British and Soviet influence in Europe ${ }^{94}$. Pol-

90 Dyskusja, która mogła mieć miejsce..., "Polska Żyje” (PŻ), 16.10.1941, No. 93, pp. 1-3; Niebezpieczeństwo komunizmu, PŻ, 18.07.1942, No. 103, p. 1; W powodzi kłamstw, PŻ, 3.06.1944, No. 144, pp. 1-2 (Komenda Obrońców Polski).

91 Tymczasowy rzad czechosłowacki, PŻ, 17.08.1940, No. 65, p. 7; Pojednanie polsko-czeskie, PŻ, 20.11.1940, No. 80-81, p. 5; O przebudowę społeczną, PŻ, 10.01.1941, No. 87, p. 2 (KOP); Punkt zwrotny w dziejach Polski, „Tygodnik Polski” (TP), 13.09.1943, No. 27, p.3; Polska a basen środkowoeuropejski, TP, 8.11.1943, No. 34, pp. 1-2 (Stronnictwo Polskiej Demokracji).

92 Istotny sens konfederacji polsko-czeskiej, TP, 10.04.1943, No. 3, p. 1; Blaski i cienie unii polskoczeskiej, TP, 10.04.1943, No. 3, pp. 2-3 (It was necessary to unitet with countries with similar potential and interests, and such is the way for Poland, the Slav policy, the union of Slavic countries, and the first seed of these new policies is the Union with the Czech Republic), (SPD).

93 Jesteśmy jednej krwi, PŻ, 30.11.1940, No. 8283, pp. 1-2 (KOP).

94 Praga-Warszawa-Moskwa, TP, 10.04.1943, No. 1, p. 2; Konflikt polsko-sowiecki, TP, 29.05.1943,
Katastrofa małych i średnich państw pokazała, że musiały razem wytworzyć ośrodek siły wobec imperialnych mocarstw od Bałtyku do Morza Śródziemnego ${ }^{91}$. Konfederacja polsko-czechosłowacka realizowała ideę solidarności zachodniosłowiańskiej, otwartą na narody niesłowiańskie Europy Środkowej i słowiańskie w ZSRR ${ }^{92}$. Była początkiem „nowej epoki rozkwitu państw słowiańskich”, która stanowiła „kamień węglowy nareszcie zrealizowanego wielkiego bloku narodów zamieszkujących międzymorze bałtycko-czarnomorskie"93. Była planowana jako obrona przed zagrożeniem niemieckim i czynnik równowagi między wpływami brytyjskimi i radzieckimi w Europie ${ }^{94}$. Polskie ideały wolności, równości i współpracy z sąsiadami prowadziły do integracji Europy Środkowej. Polska musiała szanować ich interesy i odrębność ${ }^{95}$. Dla bezpieczeństwa Polski i sprawiedliwości dziejowej Niem-

W powodzi kłamstw, PŻ, 3.06.1944, nr 144, s. 1-2 (Komenda Obrońców Polski).

91 Tymczasowy rząd czechosłowacki, PŻ, 17.08.1940, nr 65, s. 7; Pojednanie polsko-czeskie, PŻ, 20.11.1940, nr 80-81, s. 5; O przebudowę społeczna, PŻ, 10.01.1941, nr 87, s. 2 (KOP); Punkt zwrotny $w$ dziejach Polski, „Tygodnik Polski” (TP), 13.09.1943, nr 27, s. 3; Polska a basen środkowoeuropejski, TP, 8.11.1943, nr 34, s. 1-2 (Stronnictwo Polskiej Demokracji).

92 Istotny sens konfederacji polsko-czeskiej, TP, 10.04.1943, nr 3, s. 1; Blaski i cienie unii polsko-czeskiej, TP, 10.04.1943, nr 3, s. 2-3 (Należało łączyć się $\mathrm{z}$ państwami o podobnym potencjale i interesach, a taką droga jest dla Polski polityka słowiańska, zwiazek państw słowiańskich, a pierwszym zaczątkiem tej nowej polityki jest właśnie unia z Czechami) (SPD).

93 Jesteśmy jednej krwi, PŻ, 30.11.1940, nr 8283, s. 1-2 (KOP).

94 Praga-Warszawa-Moskwa, TP, 10.04.1943, nr 1, s. 2; Konflikt polsko-sowiecki, TP, 29.05.1943, nr 10, s. 1-2; Na sowieckim zakręcie, TP, 11.10.1943, nr 30, s. 1-2 (SPD).

95 O tym pomyślcie w Londynie, PŻ, 5.06.1942, 
ish ideals of freedom, equality and cooperation with neighbors led to the integration of Central Europe. Poland was to respect their interests and distinctiveness ${ }^{95}$. For the sake of Poland's security and historical justice Germany would lose the Slavic lands to the Oder, Lusatian Neisse and Lusatia. The Germanized Slavic populations of these lands would soon return to the Polish nation after the war ${ }^{96}$. When the Western powers recognized Central Europe as a Soviet sphere of influence, the SPD (Stronnictwo Polskiej Demokracji the Polish Democratic Party) and the KOP (Korpus Obrońców Polski - the Defenders of Poland Corps) supported the anti-German Slavic alliance of Poland, the USSR and Czechoslovakia ${ }^{97}$. They hoped that for the security of the western borders of the USSR, its participants would retain independence and territorial integrity ${ }^{98}$.

Since the war with Germany, the USSR had replaced the revolutionary slogans with the Slavic idea and "national communism". Since the Bolshevik Revolution in 1917, the Soviet authorities had fought the Slavic idea. In 1939, they supported Germany's aggression against Slavic states and demanded their territories. Therefore, they could not join the imperial plans of

No. 10, pp. 1-2; Na sowieckim zakręcie, TP, 11.10.1943, No. 30, pp. 1-2 (SPD).

95 O tym pomyślcie w Londynie, PŻ, 5.06.1942, No. 101, p. 4; Wista frontem ducha polskiego, PŻ, 8.08.1942, No. 104, pp. 1-2 (KOP).

96 Wielki Plan radcy ministerialnego, TP, 26.06.1943, No. 14, pp. 2-3; Na progu zwycięstwa, TP, 16.08.1943, No. 20, p. 2 (SPD).

97 Polska - Rosja - Czechosłowacja, „Głos Demokracji” (GD), 23.09.1944, No. 1, p. 1 (SPD).

98 Warszawa-Praga-Moskwa, GD, 10.01.1944, No. 42, pp. 1-3; Werbalizm demokratyczny już nie wystarcza, GD, 27.02.1944, No. 44, pp. 2-4 (SPD). cy straciłyby ziemie słowiańskie do Odry i Nysy Łużyckiej oraz Łużyce. Zgermanizowana ludność słowiańska tych ziem po wojnie szybko wróciłaby na łono narodu polskiego ${ }^{96}$. Gdy zachodnie mocarstwa uznały Europę Środkową za radziecką strefę wpływów, SPD i KOP poparły antyniemiecki sojusz słowiański Polski, ZSRR i Czechosłowacji ${ }^{97}$. Liczyły, że za gwarancje bezpieczeństwa zachodnich granic ZSRR jego uczestnicy zachowaliby niepodległość i integralność terytorialną ${ }^{98}$.

Od wojny z Niemcami ZSRR zastąpił rewolucyjne hasła ideą słowiańską i „narodowym komunizmem". Od rewolucji bolszewickiej w 1917 r. radzieckie władze zwalczały ideę słowiańską. W 1939 r. wspierały agresję Niemiec na państwa słowiańskie i wysuwały żądania do ich ziem. Dlatego nie mogły się wiązać $\mathrm{z}$ imperialnymi planami ZSRR, jak i z Niemcami ${ }^{99}$. Ugrupowania centrowe wskazywały, że kierował się potrzebą antyniemieckiej dywersji w Europie i imperializmem wobec

nr 101, s. 4; Wisła frontem ducha polskiego, PŻ, 8.08.1942, nr 104, s. 1-2 (KOP).

96 Wielki Plan radcy ministerialnego, TP, 26.06.1943, nr 14, s. 2-3; Na progu zwycięstwa, TP, 16.08.1943, nr 20, s. 2 (SPD).

${ }^{97}$ Polska - Rosja - Czechosłowacja, „Głos Demokracji” (GD), 23.09.1944, nr 1, s. 1 (SPD).

98 Warszawa-Praga-Moskwa, GD, 10.01.1944, $\mathrm{nr}$ 42, s. 1-3; Werbalizm demokratyczny już nie wystarcza, GD, 27.02.1944, nr 44, s. 2-4 (SPD).

${ }_{99}$ Metody zbrodniarzy, ,Jutro PN”, 18.07.1941, $\mathrm{nr}$ 105, s. 2-3; Rozstrzelani przez bolszewików, „Jutro PN", 24.10.1941, nr 116, s. 4 (Polska Niepodległa); Warunki poprawnych stosunków $z$ Rosja, ,Jutro PN", 3.04.1942, nr 11, s. 2; Kominternowskie prowokacje, „Jutro PN", 15.05.1942, nr 17, s. 1; Strzeżmy się propagandy wroga, „Jutro PN”, 27.02.1943, nr 9, s. 1-3 (Polska Niepodległa); Musimy wygrać pokój, „Kadra PN”, 7.01.1943, nr 11, s. 2-4; Wstyd dłużej milczeć, „Kadra PN”, 16.09.1943, nr 27, s. 3-4 (Kadra Polski Niepodległej). 
the USSR as well as Germany ${ }^{99}$. Central groups indicated that the USSR was guided by the need for anti-German diversion in Europe and imperialism towards the Slavic nations ${ }^{100}$. It created alternative sources of power in Moscow to emigrate governments, especially Slav countries. The "Slavonic Comintern" supported pro-Soviet propaganda in occupied Europe, the United Kingdom and America ${ }^{101}$. They did not invite the representatives of the "Slavic Polish Embassy" to the Slavonic congresses in Moscow, because the "Slavic" Communists were implementing the policy of the "Slavic Moscow" and organizing the "Slavic partisans" 102 . With the help of the Slavic propaganda the communist strengthened its influence in the Slavic nations ${ }^{103}$. The PPR, as a nationalized communist party, was to undermine the Polish vision of Central European order and facilitate the en-

99 Metody zbrodniarzy, "Jutro PN", 18.07.1941, No. 105, pp. 2-3; Rozstrzelani przez bolszewików, "Jutro PN”, 24.10.1941, No. 116, p. 4 (Polska Niepodległa); Warunki poprawnych stosunków z Rosja, "Jutro PN", 3.04.1942, No. 11, p. 2; Kominternowskie prowokacje, "Jutro PN", 15.05.1942, No. 17, p. 1; Strzeżmy się propagandy wroga, "Jutro PN”, 27.02.1943, No. 9, pp. 1-3 (Polska Niepodległa); Musimy wygrać pokój, "Kadra PN", 7.01.1943, No. 11, pp. 2-4; Wstyd dtużej milczeć, "Kadra PN", 16.09.1943, No. 27, pp. 3-4 (Kadra Polski Niepodległej).

100 Amerykańscy Słowianie, "Nowe Drogi", 21.01.1942, No. 2, pp. 10-11; Istotny sens konfederacji, "Nowe Drogi", 15.02.1943, No. 18, pp. 2-3 (Stronnictwo Demokratyczne); O stosunek do Rosji, "Wolna Polska”, 17.12.1941, No. 33, p. 48; Bolszewicy, "Wolna Polska", 29.04.1942, No. 51, p. 136 (Związek Odbudowy Rzeczypospolitej, od 1944 Związek Wolnej Polski).

101 Na co liczy Rosja?, "Kadra PN", 12.08.1943, No. 25, pp. 2-3 (KPN).

102 Słowianie na Kremlu, "Jutro PN", 30.05.1942, No. 19, pp. 1-2 (PN).

103 Amerykańscy Słowianie, "Nowe Drogi", 21.01.1942, No. 2, p. 11 (SD). narodów słowiańskich ${ }^{100}$. Tworzył w Moskwie alternatywne ośrodki władzy wobec emigracyjnych rządów, szczególnie państw słowiańskich. „Komintern Słowiański” wspierał proradziecką propagandę w okupowanej Europie, Wielkiej Brytanii i Ameryce ${ }^{101}$. Na kongresy słowiańskie w Moskwie nie zapraszano przedstawicieli „słowiańskiej ambasady polskiej”, ponieważ to „słowiańscy” komuniści realizowali politykę „słowiańskiej Moskwy” i organizowali „słowiańską partyzantkę"102. Słowiańską propagandą komuniści umacniali jego wpływy w słowiańskich narodach ${ }^{103}$. PPR jako unarodowiona partia komunistyczna miała nią przekreślić polską wizję ładu środkowoeuropejskiego i ułatwić zniewolenie Polski ${ }^{104}$. Słowiańskość w Polsce miała negatywny wydźwię $k^{105}$, gdyż łączyło się ją z panslawizmem, skrywają-

100 Amerykańscy Słowianie, „Nowe Drogi”, 21.01.1942, nr 2, s. 10-11; Istotny sens konfederacji, „Nowe Drogi”, 15.02.1943, nr 18, s. 2-3 (Stronnictwo Demokratyczne); O stosunek do Rosji, „Wolna Polska”, 17.12.1941, nr 33, s. 48; Bolszewicy, „Wolna Polska”, 29.04.1942, nr 51, s. 136 (Związek Odbudowy Rzeczypospolitej, od 1944 Związek Wolnej Polski).

101 Na co liczy Rosja?, „Kadra PN”, 12.08.1943, nr 25, s. 2-3 (KPN).

102 Słowianie na Kremlu, „Jutro PN”, 30.05.1942, nr 19, s. 1-2 (PN).

103 Amerykańscy Słowianie, „Nowe Drogi”, 21.01.1942, nr 2, s. 11 (SD).

104 Niebezpieczna pora, „Kadra PN”, 10.12.1942, nr 9, s. 3-4; Nowy okres - nowe zadania, „Kadra PN”, 4.02.1943, nr 12, s. 3-4; Likwidować prowokację komunistyczną; Rozwiazanie Kominternu oszustwem, co mówi tajny dokument komunistyczny, „Kadra PN”, 2.09.1943, nr 26, s. 4-6 (KPN); PPR na Lubelszczyźnie, „Jutro PN”, 16.10.1943, nr 41, s. 3 (PN).

105 Moskiewscy Słowianie, „Wolna Polska”, 6.03.1942, nr 17, s. 119 (ZOR); T. Kulak, Jan Ludwik Popławski. Biografia polityczna, Wrocław 1994, s. 53; M. Dymarski, Słowiańszczyzna w myśli politycznej Jana Ludwika Popławskiego i Leona Wasilewskiego, [w:] Europa Środkowo-Wschodnia..., s. 7-26. 
slavement of Poland ${ }^{104}$. Slavicity in Poland had a negative impact ${ }^{105}$, because it was associated itself with Pan-Slavism, which hid Russian imperialism. Moscow treated the Slavic idea as a tool. The Central European Federation distinguished Slavicity from others in Europe, and its Western European culture from Russia ${ }^{106}$. The PolishCzechoslovak and Yugoslav-Greek unions would unite the Slavs, creating a belt of freedom and democracy between Germany and the USSR ${ }^{107}$. They would have common political, economic and social inter-

104 Niebezpieczna pora, "Kadra PN”, 10.12.1942, No. 9, pp. 3-4; Nowy okres - nowe zadania, "Kadra PN", 4.02.1943, No. 12, pp. 3-4; Likwidować prowokację komunistyczną; Rozwiązanie Kominternu oszustwem, co mówi tajny dokument komunistyczny, "Kadra PN", 2.09.1943, No. 26, pp. 4-6 (KPN); PPR na Lubelszczyźnie, "Jutro PN”, 16.10.1943, No. 41, p. $3(\mathrm{PN})$.

105 Moskiewscy Słowianie, "Wolna Polska", 6.03.1942, No. 17, p. 119 (ZOR); T. Kulak, Jan Ludwik Popławski. Biografia polityczna, Wrocław 1994, p. 53; M. Dymarski, Słowiańszczyzna w myśli politycznej Jana Ludwika Popławskiego i Leona Wasilewskiego, [in:] Europa Środkowo-Wschodnia..., pp. 7-26.

106 Nie tędy droga, „Wolna Polska”, 4.03.1942, No. 9, p. 17, (ZOR believed that, in the fight against Germany, Poland joined the brotherhood of arms with Russia. The unity of the Slavic nations was seen as a community of free and sovereign nations in cooperation with Russia, and not under its pan-Slavic hegemony.); W czwartym roku walki o jutro, "Jutro PN", 7.11.1942, No. 29, p. 2 (PN); Organizacja nowej Europy, "Nowe Drogi", 6.03.1942, No. 5, pp. 1-4; Istotny sens konfederacji, "Nowe Drogi", 15.02.1943, No. 18, pp. 2-3 (SD); Moskwa odstania przyłbice, “Kadra PN", 18.03.1943, No. 15, pp. 1-3 (KPN).

107 AMR, KGAK, BIP, sygn. 203/VII-48, "Wolna Polska”, Do czego dażymy, referat 4, program grupy politycznej, p. 256, (Panslavism concealed the Great Russian imperialism that led the Eurasian nations of the Russian Empire); Ogólne wiadomości radiowe, „Jutro PN", 9.11.1940, No. 77, p. 4; Unia polsko-czeska, „Jutro PN”, 29.11.1940, No. 80, pp. 1-2; Konfederacja polsko-czechosłowacka, "Jutro PN", 6.02.1942, No. 6, p. 1; Idea konfederacji, "Jutro PN", 4.12.1943, No. 48, pp. 2-3 (PN); Praga - Warszawa - Mosk$w a$, „Nowe Drogi”, 15.02.1943, No. 18, pp. 3-4 (SD); cym rosyjski imperializm. Ideę słowiańską Moskwa traktowała instrumentalnie. Federację środkowoeuropejską odróżniała od innych w Europie słowiańskość, a od Rosji jej zachodnioeuropejska kultura ${ }^{106}$. Związki polsko-czechosłowacki i jugosłowiańsko-grecki jednoczyłyby Słowiańszczyznę, tworząc pas wolności i demokracji między Niemcami a ZSRR ${ }^{107}$. Łączyłyby je interesy polityczne, gospodarcze i społeczne oraz wspólna obrona wobec imperialnych mocarstw. Nie mogły słowiańskie sentymenty stanowić ich ideowej podstawy, bo było w nich miejsce dla niesłowiańskich narodów. Miały też propagować ideę jedności Europy ${ }^{108}$. Demokra-

106 Nie tędy droga, „Wolna Polska”, 4.03.1942, nr 9, s. 17 (ZOR uważał, że w walce z Niemcami łączyło Polskę braterstwo broni z Rosją. Jedność narodów słowiańskich widział jako wspólnotę wolnych i suwerennych narodów we współpracy z Rosją, a nie pod jej panslawistyczną hegemonią); $W$ czwartym roku walki o jutro, „Jutro PN”, 7.11.1942, nr 29, s. 2 (PN); Organizacja nowej Europy, „Nowe Drogi", 6.03.1942, nr 5, s. 1-4; Istotny sens konfederacji, „Nowe Drogi”, 15.02.1943, nr 18, s. 2-3 (SD); Moskwa odsłania przyłbice, „Kadra PN”, 18.03.1943, nr 15, s. 1-3 (KPN).

107 AAN, KGAK, BIP, sygn. 203/VII-48, „Wolna Polska”, Do czego dażymy, referat 4, program grupy politycznej, s. 256 (Panslawizm skrywał wielkorosyjski imperializm, który przewodził euroazjatyckim ludom mocarstwa rosyjskiego); Ogólne wiadomości radiowe, "Jutro PN", 9.11.1940, nr 77, s. 4; Unia polsko-czeska, „Jutro PN”, 29.11.1940, nr 80, s. 1-2; Konfederacja polsko-czechosłowacka, "Jutro PN", 6.02.1942, nr 6, s. 1; Idea konfederacji, "Jutro PN", 4.12.1943, nr 48, s. 2-3 (PN); Praga - Warszawa Moskwa, „Nowe Drogi”, 15.02.1943, nr 18, s. 3-4 (SD); Jugosławia walcząca, „Kadra PN”, 1.04.1943, nr 16, s. 12 (KPN).

108 Organizacja nowej Europy, „Nowe Drogi”, 6.03.1942, nr 5, s. 1-4 (SD); Kadra i jej cele, „Kadra PN”, 26.08.1942, nr 1, s. 165; Musimy wygrać pokój, „Kadra PN”, 7.01.1943, nr 11, s. 3-4; My a Europa Środkowa, „Kadra PN”, 2.09.1943, nr 26, s. 1-3 (KPN); AAN, KGAK, BIP, sygn. 203/VII-48, Do Polaków, Białorusinów, Estończyków, Litwinów, Łotyszów i Ukraińców, 1943, s. 269 (ZOR głosił, że 
ests, and joint defense against the imperial powers. Slavic sentiments could not be their ideological basis because non-Slavic nations could join them. They were also to promote the idea of unity of Europe ${ }^{108}$. Democracy, human rights and Christian ethics would be the foundation of its system ${ }^{109}$. Poland would take the Slavic lands to the Oder and Lusatian Neisse from Germany, and would Polonize the Germanized Slavs ${ }^{110}$. Slavonic minorities in Poland would have full civil, national, cultural and religious rights ${ }^{111}$. The Lusatian nation would regain independence within Poland in order to participate in the construction of the "Great Slavs"112. With the exception of the Czech Republic, no one

Jugosławia walczaca, “Kadra PN”, 1.04.1943, No. 16, p. $12(\mathrm{KPN})$.

108 Organizacja nowej Europy, "Nowe Drogi", 6.03.1942, No. 5, pp. 1-4 (SD); Kadra i jej cele, "Kadra PN", 26.08.1942, No. 1, p. 165; Musimy wygrać pokój, "Kadra PN", 7.01.1943, No. 11, pp. 3-4; My a Europa Środkowa, "Kadra PN", 2.09.1943, No. 26, pp. 1-3 (KPN); AMR, KGAK, BIP, sygn. 203/VII-48, Do Polaków, Białorusinów, Estończyków, Litwinów, Łotyszów i Ukraińców, 1943, p. 269 (ZOR proclaimed that the Germans and Russians made the nations of the Baltic-Black Sea slaves and colonized their lands. When for them Tsarist Russia was a prison, Soviet Russia is their cemetery. The Association of Free and Sovereign Nations from the Baltic to the Black Sea guaranteed them freedom and security).

109 Hipokryci, "Nowe Drogi", 9.06.1942, No. 8, p. 1; Organizacja nowej Europy, "Nowe Drogi", 6.03.1942, No. 5, pp. 1-4; O nowe demokratyczne podstawy stosunków międzynarodowych, "Nowe Drogi", 20.02.1942, No. 4, pp. 3-5; Nowe demokratyczne podstawy stosunków międzynarodowych, "Nowe Drogi", 6.03.1942, No. 5, pp. 5-7.

${ }_{110} M y$ - a Europa Środkowa, "Kadra PN", 2.09.1943, No. 26, pp. 1-3.

111 AMR, KGAK, BIP, sygn. 203/VII-48, „Wolna Polska”, Do czego dążymy, referat 4, program grupy politycznej, p. 25.

112 Sprawa Serbo-Łużycka, "Jutro PN", 10.04.1943, No. 14, p. 3. cja, prawa człowieka i etyka chrześcijańska stanowiłaby fundament jej ustroju ${ }^{109}$. Polska odebrałaby Niemcom ziemie słowiańskie do Odry i Nysy Łużyckiej, a zniemczonych Słowian spolonizowała ${ }^{110}$. Mniejszości słowiańskie w Polsce posiadałyby pełnię praw obywatelskich, narodowych, kulturalnych i religijnych ${ }^{111}$. Naród łużycki odzyskałby niezależność w ramach Polski, aby uczestniczył w budowie „Wielkiej Słowiańszczyzny"112. Poza Czechami nikt w Europie Środkowej nie czekał na radzieckie wyzwolenie ${ }^{113}$.

Wśród grup centrowych Polski Związek Wolności uczynił ideę słowiańską swoją doktryną polityczną. Był za powołaniem Związku Ogólnosłowiańskiego, który zrzeszałby słowiańskie organizacje podziemne ${ }^{114}$. W Europie Środkowej, którą utożsamiał z historycznym obszarem

z narodów międzymorza bałtycko-czarnomorskiego Niemcy i Rosjanie robili niewolników i kolonizowali ich ziemie. Gdy dla nich carska Rosja była więzieniem, to Rosja sowiecka jest ich cmentarzem. Związek Wolnych i Suwerennych Narodów od Bałtyku do Morza Czarnego gwarantował im wolność i bezpieczeństwo).

${ }^{109}$ Hipokryci, ,Nowe Drogi”, 9.06.1942, nr 8, s. 1; Organizacja nowej Europy, "Nowe Drogi”, 6.03.1942, nr 5, s. 1-4; O nowe demokratyczne podstawy stosunków międzynarodowych, „Nowe Drogi”, 20.02.1942, nr 4, s. 3-5; Nowe demokratyczne podstawy stosunków międzynarodowych, „Nowe Drogi”, 6.03.1942, nr 5, s. 5-7.

${ }^{110}$ My - a Europa Środkowa, „Kadra PN”, 2.09.1943, nr 26, s. 1-3.

111 AAN, KGAK, BIP, sygn. 203/VII-48, „Wolna Polska”, Do czego dążymy, referat 4, program grupy politycznej, s. 25.

112 Sprawa Serbo-Łużycka, „Jutro PN", 10.04.1943, nr 14, s. 3 .

113 Ofensywa rosyjska a losy Europy, „Kadra PN", 18.03.1943, nr 15, s. 5-6.

${ }^{114}$ Nasz program, „Radło”, 30.12.1942, nr 1-6, s. 4; (W 1940 r. ZOR założył miesięcznik „Radło”. Odwieczny słowiański symbol narzędzie pracy $i$ walki Słowian oraz ich jedności. Kształt radła miała Wi- 
in Central Europe was waiting for the Soviet liberation ${ }^{113}$.

Among the center groups the Polish Union of Freedom (PZW) made the Slavic idea its political doctrine. It was in favor of the establishment of the Pan-Slavic Union, which would associate Slavic underground organizations ${ }^{114}$. In Central Europe, which it identified with the historical Slavic area, the Great Slavonic Community from the Baltic to the Adriatic and the Black Sea (the Union of Slavonic States and Nations) would be formed ${ }^{115}$. The Polish-CzechSlovak Confederation Agreement, initiated by Poland, and the Yugoslav-Greek Union, the defense arm of the Slavs, were its foundation ${ }^{116}$. After the war, Yugoslavia and Czechoslovakia would be reborn as the federal states ${ }^{117}$. Poles, Czechs, Slovaks, Croats, Serbs, Slovenes, Bulgarians would set up a close political, economic and mil-

113 Ofensywa rosyjska a losy Europy, "Kadra PN", 18.03.1943, No. 15, pp. 5-6.

114 Nasz program, „Radło”, 30.12.1942, No. 1-6, p. 4; (In 1940, ZOR founded the monthly journal "Radło" (wooden plough). The eternal Slavic symbol of the tool of work and struggle of the Slavs and their unity. The Vistula had the shape of a wooden plough, [in:] Radło, "Radło", 1941, No. 4, pp. 1-2.); S. Fertacz, Polska myśl słowiańska, p. 76.

115 Hannibal ante portas, "Radło", 1941, No. 4, pp. 8-9; Początek Słowian, "Radło", 30.12.1942, No. 1-6, p. 10; Cele Polskiego Związku Wolności, "Radło", marzec 1943, No. 3, pp. 1-2, 6.

116 Konfederacja polsko-czechosłowacka, "Głos Prawdy", 27.01.1942, No. 140, p. 75; Rosja i polityka polska, "Głos Prawdy", 10.02.1942, No. 142, pp. 108-109 (ZOR); Nasz program, "Radło", 30.12.1942, No. 1-6, pp. 4-5; O zasadnicza wartość umowy polsko-czechosłowackiej, "Radło", styczeń-luty 1943, No. 1-2, pp. 5-6.

117 AMR, DR, DIP, Sekcja Zachodnia (SZ), sygn. 202/III-148, PZW, Zagadnienie czechosłowackie, konferencja zachodnia, Warszawa 9.01.1944, pp. 352-353; Serbowie, Słoweńcy, Chorwaci, "Radło", styczeń 1944, No. 1, pp. 13-14. słowiańskim, powstałaby Wielka Wspólnota Słowiańska od Bałtyku do Adriatyku i Morza Czarnego (Unia Państw i Narodów Słowiańskich) ${ }^{115}$. Jej podstawą były zainicjowane przez Polskę umowy o konfederacji polsko-czesko-słowackiej i unii jugosłowiańsko-greckiej, szaniec obronny Słowiańszczyzny ${ }^{116}$. Po wojnie odrodziłyby się już jako federalne państwa Jugosławia i Czechosłowacja ${ }^{117}$. Polacy, Czesi, Słowacy, Chorwaci, Serbowie, Słoweńcy, Bułgarzy powołaliby ścisły związek polityczny, gospodarczy i wojskowy, a z czasem jedno państwo. Mogli się z nim integrować Białorusini i Ukraińcy oraz historycznie związane ze Słowianami Węgry, Rumunia, państwa bałtyckie i Grecja ${ }^{118}$. Mniejszości słowiańskie posiadałyby prawo swobodnego rozwoju ${ }^{119}$. Polska przywróciłaby granicę Bolesława Chrobrego: Rugia, Odra,

sła, [w:] Radło, „Radło”, 1941, nr 4, s. 1-2.); S. Fertacz, Polska myśl słowiańska, s. 76.

115 Hannibal ante portas, „Radło”, 1941, nr 4, s. 8-9; Początek Słowian, „Radło”, 30.12.1942, nr 1-6, s. 10; Cele Polskiego Związu Wolności, „Radło”, marzec 1943, nr 3, s. 1-2, 6.

116 Konfederacja polsko-czechosłowacka, „Głos Prawdy”, 27.01.1942, nr 140, s. 75; Rosja i polityka polska, „Głos Prawdy”, 10.02.1942, nr 142, s. 108-109 (ZOR); Nasz program, „Radło”, 30.12.1942, nr 1-6, s. 4-5; O zasadniczq wartość umowy polsko-czechosłowackiej, „Radło”, styczeń-luty 1943, nr 1-2, s. 5-6.

117 AAN, DR, DIP, Sekcja Zachodnia (SZ), sygn. 202/III-148, PZW, Zagadnienie czechosłowackie, konferencja zachodnia, Warszawa 9.01.1944, s. 352-353; Serbowie, Słoweńcy, Chorwaci, „Radło”, styczeń 1944, nr 1, s. 13-14.

118 Austria i Europa Środkowa, „Radło”, grudzień 1943, nr 10-12, s. 3-5; AAN, DR, DIP, SZ, sygn. 202/III-148, PZW, Misja dziejowa Polski na zachodzie; Współpraca ze Słowianami Zachodnio-południowymi, Rola Polski jako ośrodka Słowiańszczyzny Zachodniej, konferencja zachodnia, Warszawa 9.01.1944, s. 349-351.

119 Wieści z kraju, „Głos Pracy”, 14.01.1943, nr 3, s. 4; Bezpieczeństwo i przyszłość bratnich narodów słowiańskich, „Radło”, marzec 1943, nr 3, s. 2-3. 
itary union and, in time, one state. Belarusians and Ukrainians and historically associated with the Slavs: Hungary, Romania, the Baltic States and Greece could integrate with it ${ }^{118}$. Slavonic minorities would have the right to free development ${ }^{119}$. Poland would restore the border of Boleslaw Chrobry: Rügen, the Oder, Lubuskie Land, Lusatia, Lusatia with Bautzen ${ }^{120}$. The Germanized Slavs would be returned to their homeland ${ }^{121}$. Hungary and Italy would give the Slavs their lands ${ }^{122}$. The connection of the Slavic area to Germany or the Soviet Union on the subordinate terms would be excluded $^{123}$. The USSR used the Slavonic idea, like the Tsarist Russia had used PanSlavism, to use the Slav nations to fight the enemy. It served to spread communism allegedly originating from the Slavic community. Until 1941 it did not care about the

118 Austria i Europa Środkowa, "Radło", grudzień 1943, No. 10-12, pp. 3-5; AMR, DR, DIP, SZ, sygn. 202/III-148, PZW, Misja dziejowa Polski na zachodzie; Współpraca ze Słowianami Zachodnio-południowymi, Rola Polski jako ośrodka Stowiańszczyzny Zachodniej, konferencja zachodnia, Warszawa 9.01.1944, pp. 349-351.

119 Wieści z kraju, “Głos Pracy”, 14.01.1943, No. 3, p. 4; Bezpieczeństwo i przyszłość bratnich narodów słowiańskich, "Radło", marzec 1943, No. 3, pp. 2-3.

120 Opodstawy polityki narodowej, "Radło", maj-lipiec 1941, No. 7, pp. 9-10; AMR, DR, DIP, SZ, sygn. 202/III-148, Zebranie PZW 9 I 1944 w Warszawie poświęcone zagadnieniom polskich Ziem Zachodnich, pp. 343a-347; PZW, Misja dziejowa Polski na zachodzie; Współpraca ze Słowianami Zachodnio-południowymi, Rola Polski jako ośrodka Stowiańszczyzny Zachodniej, konferencja zachodnia, Warszawa 9.01.1944, pp. 349-351.

121 Cele Polskiego Związku Wolności, "Radło", marzec 1943, No. 3, p. 1.

122 Prusy południa. Po kapitulacji Włoch, "Radło", grudzień 1943, No. 10-12, p. 9.

123 Słowiańszczyzna pod niemiecka okupacja, “Głos Pracy”, 19.12.1942, No. 50, pp. 4-5; Edvard Beneš, "Radło", luty-marzec 1944, No. 2-3, pp. 4-8.
Ziemia Lubuska, Nysa Łużycka, Łużyce z Budziszynem ${ }^{120}$. Do macierzy wróciliby zniemczeni Słowianie ${ }^{121}$. Węgry i Włochy oddałyby Słowianom ich ziemie ${ }^{122}$. Wykluczone było wiązanie się obszaru słowiańskiego z Niemcami lub ZSRR na zasadzie podległości ${ }^{123}$. ZSRR posługiwał się ideą słowiańską, jak carska Rosja panslawizmem, aby wykorzystać narody słowiańskie do walki z wrogim mocarstwem. Służyła do szerzenia komunizmu rzekomo wywodzącego się ze słowiańskiej wspólnoty. Do 1941 r. nie przejmował się narodami słowiańskimi pod okupacją niemiec$\mathrm{ką}^{124}$. W Polsce występowała stała obawa przed ideą słowiańską ${ }^{125}$. PZW ostrzegał przed wykorzystywaniem jej do budowy polskiego imperium. W XVII w. polski imperializm zaprzepaścił szansę zjednoczenia Słowiańszczyzny ${ }^{126}$. Od imperialnych rosyjskich doktryn słowiańskich polska różniła się zasadą „wolni z wolnymi, rów-

120 Opodstawy polityki narodowej, „Radło”, maj-lipiec 1941, nr 7, s. 9-10; AAN, DR, DIP, SZ, sygn. 202/III-148, Zebranie PZW 9 I 1944 w Warszawie poświęcone zagadnieniom polskich Ziem Zachodnich, s. 343a-347; PZW, Misja dziejowa Polski na zachodzie; Współpraca ze Słowianami Zachodnio-południowymi, Rola Polski jako ośrodka Słowiańszczyzny Zachodniej, konferencja zachodnia, Warszawa 9.01.1944, s. 349-351.

121 Cele Polskiego Związku Wolności, „Radło”, marzec 1943, nr 3, s. 1.

122 Prusy południa. Po kapitulacji Włoch, „Radło", grudzień 1943, nr 10-12, s. 9.

123 Słowiańszczyzna pod niemiecka okupacja, „Głos Pracy”, 19.12.1942, nr 50, s. 4-5; Edvard Beneš, „Radło”, luty-marzec 1944, nr 2-3, s. 4-8.

124 Podstawy, „Radło”, grudzień 1943, nr 1012, s. 9-12.

125 Podstawy, „Radło”, marzec 1943, nr 3, s. 3-4.

126 Współpraca polsko-czechosłowacka, „Radło”, styczeń-luty 1943, nr 1-2, s. 8; Tradycje polityki polskiej, „Radło”, grudzień 1943, nr 10-12, s. 1-3. 
Slavic nations under Nazi occupation ${ }^{124}$. In Poland, there was constant fear of the Slavic idea ${ }^{125}$. PZW warned against using it to build the Polish empire. In the seventeenth century, Polish imperialism had failed to unite the Slavs ${ }^{126}$. From the imperial Russian Slavonic doctrines, the Polish one differed in the principle of "the free with the free, the equal with the equal" ${ }^{127}$. PZW regreted that the Czechs underwent Russian Slavonic doctrines in the nineteenth and twentieth centuries ${ }^{128}$. The Treaty with Beneš served the USSR to shift its strategic borders to the Oder and the Alps ${ }^{129}$.

The Polish Movement of the Slavic Union believed that the Polish national interest was the establishment of a West Slavic state with equal rights for the member nations that would have legal guarantees of free development ${ }^{130}$. A Pole would stand at the helm as the Polish nation was the largest. For balance in the union government, each member nation would have its own representative, and their offices would be only for their representatives. The Parliament would come from the di-

124 Podstawy, “Radło", grudzień 1943, No. 1012, pp. 9-12. $3-4$.

125 Podstawy, "Radło", marzec 1943, No. 3, pp.

126 Współpraca polsko-czechosłowacka, "Radło", styczeń-luty 1943, No. 1-2, p. 8; Tradycje polityki polskiej, "Radło", grudzień 1943, No. 10-12, pp. 1-3.

127 Polska orientacja słowiańska, "Radło", styczeń 1944, No. 1, pp. 8-10.

128 Podstawy, “Radło", grudzień 1943, No. 1012, pp. 9-12.

129 Bilans, "Radło", styczeń 1944, No. 1, p. 1.

130 Silna Polska - równoważnik sił $w$ Europie Środkowej, "Młoda Myśl", 10 XII 1942, No. 1, pp. 4-6; Punkt wyjścia, "Myśl Wyzwolona”, 15 XI 1942, No. 12, pp. 1-2; Ustrój polityczny Rzeczypospolitej, "Myśl Wyzwolona”, 12 XII 1942, No. 13, pp. 2-4; Imperium polskie, "Myśl Wyzwolona", 1 II 1943, No. 1, pp. 1-2. ni z równymi” ${ }^{127}$. PZW ubolewał, że Czesi ulegali rosyjskim doktrynom słowiańskim w XIX i XX w. ${ }^{128}$ Układ Benešem służył ZSRR do przesunięcia strategicznych granic do Odry i Alp ${ }^{129}$.

Polski Ruch Zjednoczenia Słowian uważał, że polską racją stanu było powołanie zachodniosłowiańskiego państwa związkowego $\mathrm{z}$ równymi prawami dla narodów członkowskich, które posiadałyby prawne gwarancje swobodnego rozwoju ${ }^{130}$. Na jego czele stałby Polak, gdyż naród polski był największy. Dla równowagi w rządzie związkowym każdy naród członkowski miałby swojego przedstawiciela, a urzędy w nich zajmowaliby tylko ich przedstawiciele. Parlament związkowy pochodziłby $\mathrm{z}$ bezpośrednich wyborów. Między Wezerą, Bałtykiem, granicami Jugosławii, polską granicą wschodnią rozciągałoby się polskie imperium słowiańskie. Polskie bezpieczeństwo wymagało, aby Polska nie była państwem etnicznym, a Niemcy i ZSRR rozpadły się na mniejsze państwa. Zrównałaby w prawach z Polakami mniejszości słowiańskie. Jej zachodnie granice biegłyby na linii Odry i Nysy Łużyckiej, a wschodnie - Dźwińsk, Połock, Mińsk, Kamieniec Podolski. Litwa byłaby częścią Polski, a niepodległa Białoruś

127 Polska orientacja słowiańska, „Radło”, styczeń 1944, nr 1, s. 8-10.

128 Podstawy, „Radło”, grudzień 1943, nr 1012, s. 9-12.

129 Bilans, „Radło”, styczeń 1944, nr 1, s. 1.

130 Silna Polska - równoważnik sił w Europie Środkowej, „Młoda Myśl”, 10 XII 1942, nr 1, s. 4-6; Punkt wyjścia, „Myśl Wyzwolona”, 15 XI 1942, nr 12, s. 1-2; Ustrój polityczny Rzeczypospolitej, „Myśl Wyzwolona”, 12 XII 1942, nr 13, s. 2-4; Imperium polskie, „Myśl Wyzwolona”, 1 II 1943, nr 1, s. 1-2. 
rect elections. The Polish Slavonic empire would extend among the Weser, the Baltic Sea, the borders of Yugoslavia, and the Polish eastern border. Polish security required that Poland was not an ethnic country, and Germany and the USSR would disintegrate into smaller states. It would equal the rights of Poles to Slavic minorities. Its western borders would run on the Odra and Lusatian Neisse lines, and the eastern - Dźwińsk (Daugavpils), Połock, Minsk, Kamieniec Podolski (KamianetsPodilskyi). Lithuania would be part of Poland. Independent Belarus and Ukraine would be part of the West Slavic state.

The peasant movement rejected the transnational forms of integration of Germany and the USSR ${ }^{131}$. It was in favor of regional federations within the democratic Union of Free Nations of Europe ${ }^{132}$. The Central European Federation from the Baltic to the Danube and the Black Sea would model on the transnational structures of western states. Its core would be the PolishCzechoslovak Confederacy, the West Slavic Commonwealth of Poles, Czechs and Slovaks ${ }^{133}$. Poles and Czechs would have tak-

131 Idea niepodległości i potęgi, "Orka”, maj 1942, No. 2, pp. 2-4; Problemy polityczne konfederacji, “Orka”, maj 1943, No. 5, pp. 4-7 (Związek Pracy Ludowej „Orka”).

132 Z zagadnień ideowo-programowych, "Przebudowa”, grudzień 1941, No. 9, p. 20; Zaczątki chłopskiej Międzynarodówki; "Przebudowa", grudzień-styczeń 1943, No. 1, pp. 3-4, 12; AMR, SL, sygn. 200/2, Zarys programu organizacji nowoczesnego państwa, p. 22; Deklaracja Ideowo-Programowa Ruchu Ludowego, luty 1944, p. 5a (Stronnictwo Ludowe); K. Przybysz, W konspiracji. Polski ruch ludowy 1939-1945, Warszawa 2010, pp. 224-226.

133 IPMS, sygn. PRM.K.15, J. Kuncewicz, Żadania i pozycja Polski w układzie powojennym, 1941, pp. 78-124; Konfederacja polsko-czechosłowacka, "Przebudowa", luty 1942, No. 2, p. 1; Co nam i Ukraina - częścią państwa zachodniosłowiańskiego.

Ruch ludowy odrzucał ponadnarodowe formy integracji Niemiec i ZSRR ${ }^{131}$. Opowiadał się za federacjami regionalnymi w ramach demokratycznego Związku Wolnych Ludów Europy ${ }^{132}$. Federacja środkowoeuropejska od Bałtyku po Dunaj i Morze Czarne wzorowałaby się na ponadnarodowych strukturach zachodnich państw. Jej rdzeń stanowiłaby konfederacja polsko-czechosłowacka, wspólne państwo zachodniosłowiańskie Polaków, Czechów i Słowaków ${ }^{133}$. Polacy i Czesi odebraliby Niemcom ziemie słowiańskie do Odry i Nysy Łużyckiej ${ }^{134}$. Do nich mogli się przyłączyć obcoplemienne państwa bałtyckie, Węgry i Rumunia ${ }^{135}$. W federacji przewagę posiadałyby narody słowiańskie na cze-

131 Idea niepodległości i potęgi, „Orka”, maj 1942, nr 2, s. 2-4; Problemy polityczne konfederacji, „Orka”, maj 1943, nr 5, s. 4-7 (Związek Pracy Ludowej „Orka”).

132 Z zagadnień ideowo-programowych, „Przebudowa”, grudzień 1941, nr 9, s. 20; Zaczątki chłopskiej Międzynarodówki; „Przebudowa”, grudzień-styczeń 1943, nr 1, s. 3-4, 12; AAN, SL, sygn. 200/2, Zarys programu organizacji nowoczesnego państwa, s. 22; Deklaracja Ideowo-Programowa Ruchu Ludowego, luty 1944, s. 5a (Stronnictwo Ludowe); K. Przybysz, W konspiracji. Polski ruch ludowy 1939-1945, Warszawa 2010, s. 224-226.

133 IPMS, sygn. PRM.K.15, J. Kuncewicz, Żqdania i pozycja Polski w układzie powojennym, 1941, s. 78-124; Konfederacja polsko-czechosłowacka, „Przebudowa”, luty 1942, nr 2, s. 1; Co nam dziś mówi idea Jagiellonów, „Przebudowa”, maj 1942, nr 5, s. 13-15; Z obranej drogi nie zejdziemy, „Polska Ludowa”, lipiec 1943, nr 4, s. 12-16; (Stronnictwo Ludowe); Sprawa konfederacji polsko-czechosłowackiej, „Orka”, kwiecień 1943, nr 4, s. 4-5.

134 Cele wojenne i zachodnie granice Polski, „Polska Ludowa”, kwiecień 1943, nr 1, s. 11-12.

135 Deklaracja ideowo-programowa, „Orka”, kwiecień 1942, nr 1, s. 4; Problemy polityczne konfederacji, „Orka”, maj 1943, nr 5, s. 10. 
en from Germany Slavic lands to the Oder and Lusatian Neisse ${ }^{134}$. The Baltic states, Hungary and Romania could join them ${ }^{135}$. In the federation, the Slav nations would prevail, led by the peasant groups ${ }^{136}$. In the south, the Balkan Slavs would unite. Hungarians and Italians would return them all Slavic lands ${ }^{137}$. Western and southern Slavs would create a political and economic bloc of nations against the Germans ${ }^{138}$. Together with the Scandinavian block they would inhibit imperialism of the USSR ${ }^{139}$. Integrated Slavic nations would play a major political and cultural role in Europe ${ }^{140}$. These might be joined by the Ukrainian and Belorussian nations that Moscow was destroying. Its Slavic politics served to dis-

dziś mówi idea Jagiellonów, "Przebudowa”, maj 1942, No. 5, pp. 13-15; Z obranej drogi nie zejdziemy, "Polska Ludowa", lipiec 1943, No. 4, pp. 12-16; (Stronnictwo Ludowe); Sprawa konfederacji polsko-czechosłowackiej, "Orka", kwiecień 1943, No. 4, pp. 4-5.

${ }^{134}$ Cele wojenne i zachodnie granice Polski, "Polska Ludowa", kwiecień 1943, No. 1, pp. 11-12.

135 Deklaracja ideowo-programowa, "Orka", kwiecień 1942, No. 1, p. 4; Problemy polityczne konfederacji, "Orka", maj 1943, No. 5, p. 10.

136 Program powszechnego wyzwolenia i postępu dla społeczności chłopskich Środkowej i Południowo-Wschodniej Europy, "Przebudowa”, grudzień-styczeń 1943, No. 1, pp. 8-12.

137 Problemy polityczne konfederacji, “Orka”, maj 1943, No. 5, pp. 7-9.

138 Problem unii gospodarczej polsko-czeskiej, "Przebudowa", luty 1942, No. 2, pp. 1-3; Plany rzadu polskiego w zakresie spraw gospodarczych, "Przebudowa”, grudzień-styczeń 1943, No. 1, pp. 17-18; E. Ponczek, Idea federacji europejskiej..., p. 194, (Jan Chyszowski, Imperializm i federacjonizm. Rozważania geopolityczne, Edinburgh-London 1942, was in favor of Union of Slavs, to oppose the concepts of Pan-European, Mitteleuropa and union of Soviet republics).

139 Z obranej drogi nie zejdziemy, "Polska Ludowa", lipiec 1943, No. 4, pp. 16-17.

140 Stanowisko ruchu ludowego w sprawie mniejszości ukraińskiej, "Polska Ludowa", kwiecień 1943, No. 1, pp. 19-20. le $\mathrm{z}$ ugrupowaniami chłopskimi ${ }^{136}$. Na południu zjednoczyliby się bałkańscy Słowianie. Węgrzy i Włosi oddaliby im wszystkie ziemie słowiańskie ${ }^{137}$. Słowianie zachodni i południowi stworzyliby polityczny i gospodarczy blok narodów przeciwko Niem$\mathrm{com}^{138}$. Razem $\mathrm{z}$ blokiem skandynawskim hamowałby imperializm ZSRR ${ }^{139}$. Zintegrowane narody słowiańskie odgrywały poważną rolę polityczną i kulturalną w Europie $^{140}$. Do nich mogłyby przystąpić narody ukraiński i białoruski, które niszczyła Moskwa. Jej słowiańska polityka służyła skłóceniu narodów słowiańskich ${ }^{141}$. Stalinowska „solidarność słowiańska” kryła w sobie taki sam imperializm jak carski panslawizm ${ }^{142}$. Polski ruch ludowy był

136 Program powszechnego wyzwolenia i postępu dla społeczności chłopskich Środkowej i Południowo-Wschodniej Europy, „Przebudowa”, grudzień-styczeń 1943, nr 1, s. 8-12.

137 Problemy polityczne konfederacji, „Orka”, maj 1943, nr 5, s. 7-9.

138 Problem unii gospodarczej polsko-czeskiej, „Przebudowa”, luty 1942, nr 2, s. 1-3; Plany rządu polskiego w zakresie spraw gospodarczych, „Przebudowa”, grudzień-styczeń 1943, nr 1, s. 17-18; E. Ponczek, Idea federacji europejskiej..., s. 194 (Jan Chyszowski, Imperializm i federacjonizm. Rozważania geopolityczne, Edynburg-Londyn 1942, opowiadał się za federacją Słowian, aby przeciwstawić się koncepcjom Paneuropy, Mitteleuropy i unii republik radzieckich).

139 Z obranej drogi nie zejdziemy, „Polska Ludowa", lipiec 1943, nr 4, s. 16-17.

140 Stanowisko ruchu ludowego w sprawie mniejszości ukraińskiej, „Polska Ludowa”, kwiecień 1943, nr 1, s. 19-20.

141 Sens naszych granic wschodnich, „Orka”, październik 1943, nr 10, s. 2-5; Sprawy wschodnie, „Polska Ludowa”, kwiecień 1943, nr 1, s. 14-18; Sowieckie jednoczenie narodu ukraińskiego, „Polska Ludowa”, luty 1944, nr 2, s. 3-4.

${ }^{142}$ Z obranej drogi nie zejdziemy, „Polska Ludowa”, czerwiec 1943, nr 3, s. 13; Na nowych drogach (J. Kuncewicz, Na nowych drogach, Londyn 1943), DP, 1.07.1943, nr 912, s. 2. 
rupt Slavic peoples ${ }^{141}$. The Stalinist "Slavonic solidarity" concealed the same imperialism as the Tsarist Pan-Slavism ${ }^{142}$. The Polish peasant movement was predestined to unite peasant Slavic nations in order to provide them with peace, security and free development. The emergence of the Slavic Central European Front required Poland's agreement with the Russian nation for the good of cooperation with the Czechs and the peoples of Yugoslavia ${ }^{143}$. In 1944 SL (People's Party) accepted an anti-German alliance with the USSR in exchange for Poland's independence, its enlargement at the expense of Germany and approval of the Central European Union ${ }^{144}$. "Orka", on the other hand, called for the government to put all its energy into creating a Central European bloc and endorsed the selfdetermination of Belarus and Ukraine ${ }^{145}$.

Pilsudski's adherents recognized the Soviet Slavonic idea as imperialism towards the Slavic nations. till the war with Germany in 1941, the USSR did not pursue domestic and tribal affinities in foreign and domestic politics ${ }^{146}$. In the alliance

141 Sens naszych granic wschodnich, "Orka”, październik 1943, No. 10, pp. 2-5; Sprawy wschodnie, "Polska Ludowa", kwiecień 1943, No. 1, pp. 14-18; Sowieckie jednoczenie narodu ukraińskiego, "Polska Ludowa", luty 1944, No. 2, pp. 3-4.

142 Z obranej drogi nie zejdziemy, "Polska Ludowa", czerwiec 1943, No. 3, p. 13; Na nowych drogach (J. Kuncewicz, Na nowych drogach, Londyn 1943), DP, 1.07.1943, No. 912, p. 2.

143 Stosunki polsko-sowieckie, "Prawda Zwycięży”, styczeń 1942, No. 6, p. 62; Sprawy wschodnie, “Polska Ludowa”, kwiecień 1943, No. 1, pp. 14-18.

144 Polska a Rosja, "Polska Ludowa", styczeń 1944, No. 1, pp. 1-4.

145 Stanowisko Rosji, “Orka”, styczeń 1944, No. 2, pp. 1-5; Na przełomie, “Orka”, marzec 1944, No. 3, pp. 6-9.

146 Zły urok Moskwy, "Polska Walczy" (PW), predestynowany do zjednoczenia chłopskich narodów słowiańskich, aby zapewnić im pokój, bezpieczeństwo i swobodny rozwój. Powstanie słowiańskiego frontu środkowoeuropejskiego wymagało porozumienia Polski z narodem rosyjskim dla dobra współpracy z Czechami i narodami Jugosławii ${ }^{143}$. W 1944 r. SL zaakceptowało antyniemiecki sojusz z ZSRR w zamian za niepodległość Polski, powiększenie jej kosztem Niemiec i zgodę na związek środkowoeuropejski ${ }^{144}$. Natomiast „Orka” postulowała, aby rząd całą energię włożył w stworzenie bloku środkowoeuropejskiego i poparł samostanowienie Białorusi i Ukrainy ${ }^{145}$.

Piłsudczycy uznali radziecką ideę słowiańską za imperializm wobec narodów słowiańskich. Do wojny z Niemcami w 1941 r. ZSRR nie kierował się w polityce zagranicznej i wewnętrznej pokrewieństwem narodowym i plemiennym ${ }^{146}$. W sojuszu z Niemcami niszczył państwa słowiańskie ${ }^{147}$. Od agresji niemieckiej, nawiązując do panslawizmu, propagował ideę słowiańską, aby je wykorzystać militarnie w czasie wojny, a po jej zakończeniu politycznie uzależnić ${ }^{148}$. Państwa słowiańskie nie mogły liczyć na jego słowiańską

143 Stosunki polsko-sowieckie, „Prawda Zwycięży”, styczeń 1942, nr 6, s. 62; Sprawy wschodnie, „Polska Ludowa”, kwiecień 1943, nr 1, s. 14-18.

144 Polska a Rosja, „Polska Ludowa”, styczeń 1944, nr 1, s. 1-4.

145 Stanowisko Rosji, „Orka”, styczeń 1944, nr 2, s. 1-5; Na przełomie, „Orka”, marzec 1944, nr 3, s. 6-9.

146 Zły urok Moskwy, „Polska Walczy” (PW), 3.07.1943, nr 11, s. 1-4; Imperializm rosyjski, PW, 24.02.1944, nr 4, s. 1-3 (Grupa „Olgierda”).

147 Wróg wschodni, „Ziemie Wschodnie Rzeczypospolitej” (ZWR), czerwiec 1943, nr 15, s. 1-5 (Grupa „Olgierda”).

148 Polska słowiańska, „Polska”, 15.04.1943, 
with Germany it destroyed the Slavonic states $^{147}$. Since the German aggression, referring to Pan-Slavism, it propagated the Slavic idea to use it militarily during the war, and after it politically subordinate ${ }^{148}$. Slavic states could not count on its Slavic solidarity and respect for their freedom ${ }^{149}$. Communism, Orthodoxy, Russian nationalism, Slavism served the Soviet imperial interests on a global scale through propaganda, communist parties, and Soviet agents ${ }^{150}$. Poland was not aware of Slavic affinity with the USSR because of its ethnic and racial composition, cultural differences, despotic regime and imperialism towards its neighbors ${ }^{151}$. The Pilsudski's adherents rejected union of Poland with Germany or the USSR ${ }^{152}$. The area between the Baltic, the Adriatic and the Black Sea constituted its natural security

3.07.1943, No. 11, pp. 1-4; Imperializm rosyjski, PW, 24.02.1944, No. 4, pp. 1-3 (Grupa “Olgierda”).

147 Wróg wschodni, "Ziemie Wschodnie Rzeczypospolitej” (ZWR), czerwiec 1943, No. 15, pp. 1-5 (Grupa “Olgierda”).

148 Polska słowiańska, "Polska”, 15.04.1943, No. 13, pp. 8-9; Dwie Rosje, “Zwrotnica”, grudzień 1943, No. 4, pp. 7-8 (Obóz Polski Walczącej).

149 Dokumenty mówią, "Wschód", 1.03.1945, No. 2, p. 2 (Bojowa Organizacja "Wschód").

150 Polityczne manewry Sowietów, "Myśl Państwowa" (MP), 18.10.1943, No. 48, pp. 2-5; Manewry polityczne Sowietów, MP, 2.11.1943, No. 49, p. 9; Manewry polityczne Sowietów, MP, 29.11.1943, No. 51 , pp. 3-4 (KON).

151 AMR, KGAK, Oddział Informacyjno-Wywiadowczy (OIW), sygn. 203/III-36, Polska między narodami, deklaracja ideowa Chłopska Organizacja Wolności "Racławice”, p. 156.

152 ZNO, PKH, sygn. 16367/II, M. Sokolnicki, Problematyka polska $w$ XX w. na tle polityki międzynarodowej, 1955, pp. 27-28; W. Paruch, Myśl polityczna obozu piłsudczykowskiego 1926-1939, Lublin 2005, pp. 596-598, 603, 613; P. Okulewicz, Koncepcja „Międzymorza” w myśli i praktyce politycznej obozu Józefa Piłsudskiego w latach 1918-1926, Poznań 2001, p. 245. solidarność i poszanowanie ich wolności ${ }^{149}$. Komunizm, prawosławie, rosyjski nacjonalizm, słowianizm służyły do realizacji imperialnych interesów państwa radzieckiego na skalę globalną za pomocą propagandy, partii komunistycznych i radzieckiej agentury ${ }^{150}$. Polska nie poczuwała się do słowiańskiego pokrewieństwa z ZSRR z powodu jego etnicznego i rasowego składu, różnic kulturowych, despotycznego ustroju i imperializmu wobec sąsiadów ${ }^{151}$. Piłsudczycy odrzucali związek Polski z Niemcami lub ZSRR ${ }^{152}$. Obszar między Bałtykiem, Adriatykiem a Morzem Czarnym stanowił jej naturalną przestrzeń bezpieczeństwa ${ }^{153}$. Polska odebrałaby Niemcom ziemie do Odry i Nysy Łużyckiej ze względów bezpieczeństwa,

nr 13, s. 8-9; Dwie Rosje, „Zwrotnica”, grudzień 1943, nr 4, s. 7-8 (Obóz Polski Walczącej).

149 Dokumenty mówia, „Wschód”, 1.03.1945, nr 2, s. 2 (Bojowa Organizacja „Wschód”).

150 Polityczne manewry Sowietów, „Myśl Państwowa” (MP), 18.10.1943, nr 48, s. 2-5; Manewry polityczne Sowietów, MP, 2.11.1943, nr 49, s. 9; Manewry polityczne Sowietów, MP, 29.11.1943, nr 51, s. 3-4 (KON).

151 AAN, KGAK, Oddział Informacyjno-Wywiadowczy (OIW), sygn. 203/III-36, Polska między narodami, deklaracja ideowa Chłopska Organizacja Wolności „Racławice”, s. 156.

152 ZNO, PKH, sygn. 16367/II, M. Sokolnicki, Problematyka polska $w X X$ w. na tle polityki międzynarodowej, 1955, s. 27-28; W. Paruch, Myśl polityczna obozu piłsudczykowskiego 1926-1939, Lublin 2005, s. 596-598, 603, 613; P. Okulewicz, Koncepcja „Międzymorza" w myśli i praktyce politycznej obozu Józefa Piłsudskiego w latach 1918-1926, Poznań 2001, s. 245.

153 Granice Polski, „Dziś i Jutro”, 15-28.02.1942, nr 19-20, s. 45; Między Niemcami i Rosja, MP, 18.12.1942, nr 32, s. 2-6 (KON); Świat pracy - spadkobierca Jagiellonów, PW, 24.01.1942, nr 2, s. 1-4; Wolni z wolnymi, równi z równymi, ZWR, maj 1943, nr 14, s. 2-5 (Grupa „Olgierda”); Deklaracja ideowa Obozu Polski Walczacej, „Polska”, 4.09.1942, s. 1-6; ZNO, PKH, sygn. 16314/II, K. Hrabyk, Co to jest Międzymorze, s. 9-13. 
space $^{153}$. Poland would take from Germans lands to the Oder and the Lusatian Neisse for safety reasons, not Slavic ones ${ }^{154}$. It was predestined to lead the Slavs ${ }^{155}$. The uniting of Czechs, Slovaks, Sorbs and Poles in one country would not give strength against Germany and the USSR ${ }^{156}$. That is why Poland would also unite with the Baltic-Black Sea and Balkan nations ${ }^{157}$. The

153 Granice Polski, "Dziś i Jutro”, 15-28.02.1942, No. 19-20, p. 45; Między Niemcami i Rosja, MP, 18.12.1942, No. 32, pp. 2-6, (KON); Świat pracy spadkobierca Jagiellonów, PW, 24.01.1942, No. 2, pp. 1-4; Wolni $z$ wolnymi, równi z równymi, ZWR, maj 1943, No. 14, pp. 2-5 (Grupa "Olgierda"); Deklaracja ideowa Obozu Polski Walczącej, "Polska", 4.09.1942, pp. 1-6; ZNO, PKH, sygn. 16314/II, K. Hrabyk, Co to jest Międzymorze, pp. 9-13.

154 AMR, OPW, sygn. 211/7, Projekt Deklaracji Komitetu Organizacyjnego OPW, 1941, pp. 3-5; Nie doceniamy możliwości naszej ekspansji na zachód, "Polska", 25.02.1942, p. 2; Nie zapominajcie o nas, "Polska", 3.12.1942, p. 4; IPMS, sygn. PRM75, Granice Wschodnie Rzeczypospolitej, Wydawnictwo "Polska Walczy", 1941, 8.01.1942, pp. 20-46.

155 Nasze jest ostateczne zwyciestwo, "Polska", 22.04.1943, No. 14, p. 1; 3 maja, "Polska", 6.05.1943, No. 16, p. 1; Otwarta gra; My a Sowiety, "Polska", 11.03.1943, No. 7-8, pp. 2-6; W nowej epoce, "Polska”, 9.03.1944, No. 3-11, p. 2 (After the dominance of the Romanesque and Germanic worlds in the Western European civilization, the Slavonic nations entered the arena, and after World War II the Slavonic epoch in the history of Europe would begin. In the new epoch, Poland would lead the primacy. Knowledge and culture will give us, the Slav society, the primacy in the new social age).

156 Czechy i Polska, PW, 24.01.1942, No. 2, pp. 7-9; Federacja czesko-polska, MP, 5.02.1942, No. 11, p. 7.

157 Nasze zadania na Ziemiach Wschodnich, "Wschód", 24.10.1942, No. 1, p. 11; Polska, Rosja i Ukraina, "Przegląd Polityczny", lipiec 1942, No. 4, pp. 196-197 (OPW); Straż na Wschodzie, „Dziś i Jutro", 16.04.1942, No. 23, p. 136; Sprawa ukraińska, "Droga", 20.12.1943, No. 43, p. 26 (KON); AMR, KGAK, OIW, sygn. 203/III-36, Polska między narodami, deklaracja ideowa ChOW "Racławice", pp. 155156; Świat pracy - spadkobierca Jagiellonów, PW, 24.01.1942, No. 2, pp. 1-4; Sprawa ukraińska w układzie międzynarodowym, ZWR, maj 1942, No. 2, pp. a nie słowiańskich ${ }^{154}$. Była predestynowana do przewodzenia Słowiańszczyźnie ${ }^{155}$. Zjednoczenie w jednym państwie Czechów, Słowaków, Łużyczan i Polaków nie dałoby siły wobec Niemiec i ZSRR ${ }^{156}$. Dlatego Polska łączyłaby się również z narodami międzymorza bałtycko-czarnomorskiego i bałkańskimi ${ }^{157}$. Piłsudczycy obawiali się uległości Jugosławii i Czechosłowacji wobec ZSRR, które zawarly z nim „słowiański” sojusz ${ }^{158}$.

154 AAN, OPW, sygn. 211/7, Projekt Deklaracji Komitetu Organizacyjnego OPW, 1941, s. 3-5; Nie doceniamy możliwości naszej ekspansji na zachód, „Polska”, 25.02.1942, s. 2; Nie zapominajcie o nas, „Polska”, 3.12.1942, s. 4; IPMS, sygn. PRM75, Granice Wschodnie Rzeczypospolitej, Wydawnictwo „Polska Walczy", 1941, 8.01.1942, s. 20-46.

155 Nasze jest ostateczne zwycięstwo, „Polska”, 22.04.1943, nr 14, s. 1; 3 maja, „Polska”, 6.05.1943, nr 16, s. 1; Otwarta gra; My a Sowiety, „Polska”, 11.03.1943, nr 7-8, s. 2-6; W nowej epoce, „Polska”, 9.03.1944, nr 3-11, s. 2 (Po dominacji świata romańskiego i germańskiego w cywilizacji zachodnioeuropejskiej na arenę weszły narody słowiańskie, a po II wojnie światowej nastanie epoka słowiańska w dziejach Europy. W nowej epoce prymat wiodłaby Polska. Wiedza i kultura dadzą nam ten prymat w epoce socjalnej - społeczności słowiańskiej).

156 Czechyi Polska, PW, 24.01.1942, nr 2, s. 7-9; Federacja czesko-polska, MP, 5.02.1942, nr 11, s. 7.

157 Nasze zadania na Ziemiach Wschodnich, „Wschód”, 24.10.1942, nr 1, s. 11; Polska, Rosja i Ukraina, „Przegląd Polityczny”, lipiec 1942, nr 4, s. 196-197 (OPW); Straż na Wschodzie, „Dziś i Jutro”, 16.04.1942, nr 23, s. 136; Sprawa ukraińska, „Droga”, 20.12.1943, nr 43, s. 26 (KON); AAN, KGAK, OIW, sygn. 203/III-36, Polska między narodami, deklaracja ideowa ChOW „Racławice”, s. 155-156; Świat pracy-spadkobierca Jagiellonów, PW, 24.01.1942, nr 2, s. 1-4; Sprawa ukraińska w układzie międzynarodowym, ZWR, maj 1942, nr 2, s. 10-12; Kwestia białoruska, ZWR, czerwiec 1942, nr 3, s. 4-7; Stosunki polsko-ukraińskie, ZWR, październik 1942, nr 7, s. 1-6; Sprawa ukraińska, ZWR, maj 1943, nr 14, s. 5-8.

158 IPMS, sygn. PRM74/3, Gdzie jest brat - konfederat, „Listy z Londynu”, 19.09.1942, nr 14, s. 114; Po układzie sowiecko-czeskim”, „Polska”, 23.12.1943, nr 49, s. 2-3; Beneš $i$ Tito, „Polska”, 30.12.1943, nr 50, s. 3-4; Delegat gen. Tito, „RS”, 5.05.1944, nr 126, s. 1 
Pilsudski's adherents were afraid of Yugoslavia and Czechoslovakia's submission to the USSR, who had concluded a "Slavonic alliance" with it ${ }^{158}$.

The Catholic-nationalist groups believed that the USSR removed itself from the family of Slav countries, betraying Czechoslovakia, Poland and Yugoslavia in an alliance with Germany ${ }^{159}$. Russia did not belong to the Slavonic world from the time of the German dynasty. It had always used the Slav nations for diversionary purposes against its enemies. Tsar or Soviet Pan-Slavism was to facilitate the partition of their lands in Central and SouthEastern Europe, ostensibly in defense of Germany. The Russians ceased to be genetically Slavic physically and culturally due to a common state with the peoples of Asia ${ }^{160}$. To the imperialism of the USSR

10-12; Kwestia białoruska, ZWR, czerwiec 1942, No. 3, pp. 4-7; Stosunki polsko-ukraińskie, ZWR, październik 1942, No. 7, pp. 1-6; Sprawa ukraińska, ZWR, maj 1943, No. 14, pp. 5-8.

158 IPMS, sygn. PRM74/3, Gdzie jest brat konfederat, "Listy z Londynu", 19.09.1942, No. 14, p. 114; Po układzie sowiecko-czeskim", "Polska", 23.12.1943, No. 49, pp. 2-3; Beneš i Tito, "Polska", 30.12.1943, No. 50, pp. 3-4; Delegat gen. Tito, "RS", 5.05.1944, No. 126, p. 1 (OPW); Sikorski - Beneš, MP, 22.06.1943, No. 40, pp. 2-5; Stosunki polsko-czeskie, MP, 30.07.1943, No. 43, p. 10; Żadnych analogii, MP, 10.01.1944, No. 53, pp. 11-14; Czechy, Rosja a demokracje Zachodu, PW, 31.07.1943, No. 11, pp. 4-5; Burza po ciszy, PW, 11.05.1944, No. 3, p. 7.

159 Rosja i Niemcy, "Warta”, 18.05.1941, No. 14, p. 1; Bolszewicy sa naszymi wrogami, "Warta", 26.0.1941, No. 23, p. 1 (Unia); Niebezpieczeństwo komunistyczne, "Polska Odrodzona" (PO), 25.04.1942, No. 1 (46), pp. 12-14; Baczność! Czerwone niebezpieczeństwo, PO, luty 1943, No. 1-2, pp. 12-13; Bezkarność zdrady, PO czerwiec 1943, No. 5, pp. 6-7 (“Znak" - Związek Odrodzenia Narodowego).

160 Straszak panslawizmu, PO, kwiecień 1944, No. 2-3, pp. 1-4 ("Znak"-ZON); Deklaracja Stronnictwa Pracy, "Reforma", 10.04.1944, No. 3, pp. 5-7; Jedyna droga, "Reforma", 31.05.1944, No. 7, pp. 1-2 (SP).
Ugrupowania katolicko-narodowe uważały, że ZSRR sam się wykreślił z rodziny państw słowiańskich, zdradzając Czechosłowację, Polskę i Jugosławię w sojuszu z Niemcami ${ }^{159}$. Rosja nie zaliczała się do świata słowiańskiego od momentu panowania w niej dynastii niemieckiej. Zawsze wykorzystywała narody słowiańskie $\mathrm{w}$ celach dywersji wobec wrogich jej mocarstw. Carski czy radziecki panslawizm miał ułatwiać zabory ich ziem w Europie Środkowej i Południowo-Wschodniej, rzekomo w obronie przed Niemcami. Rosjanie przestali być genetycznymi Słowianami fizycznie i kulturowo z racji wspólnego państwa z ludami Azji ${ }^{160}$. Imperializmowi ZSRR, jak i Niemiec, Polska przeciwstawiła ideę pokojowego sfederowania Słowian (Unia Środkowoeuropejska i blok bałkański) w ramach Imperium Słowiańskiego między Bałtykiem, Adriatykiem i Morzem Czarnym, łącznie z narodami wschodni$\mathrm{mi}^{161}$. Polska oparłaby je na wolności, spra-

(OPW); Sikorski - Beneš, MP, 22.06.1943, nr 40, s. 2-5; Stosunki polsko-czeskie, MP, 30.07.1943, $\mathrm{nr}$ 43, s. 10; Żadnych analogii, MP, 10.01.1944, nr 53, s. 11-14; Czechy, Rosja a demokracje Zacho$d u$, PW, 31.07.1943, nr 11, s. 4-5; Burza po ciszy, PW, 11.05.1944, nr 3, s. 7.

159 Rosja i Niemcy, „Warta”, 18.05.1941, nr 14, s. 1; Bolszewicy sq naszymi wrogami, "Warta", 26.0.1941, nr 23, s. 1 (Unia); Niebezpieczeństwo komunistyczne, „Polska Odrodzona” (PO), 25.04.1942, nr 1 (46), s. 12-14; Baczność! Czerwone niebezpieczeństwo, PO, luty 1943, nr 1-2, s. 12-13; Bezkarność zdrady, PO czerwiec 1943, nr 5, s. 6-7 („Znak” - Związek Odrodzenia Narodowego).

160 Straszak panslawizmu, PO, kwiecień 1944, nr 2-3, s. 1-4 („Znak” - ZON); Deklaracja Stronnictwa Pracy, „Reforma”, 10.04.1944, nr 3, s. 5-7; Jedyna droga, „Reforma”, 31.05.1944, nr 7, s. 1-2 (SP).

161 Zagadnienie federacji środkowoeuropejskiej, cz. 1, PO, 25.04.1942, nr 1 (46), s. 8-12; Zagadnienie Bloku Środkowo-Europejskiego, cz. 2, PO, 23.05.1942, nr 2 (47), s. 6-10; O mocarstwowości, PO, 23.05.1942, nr 2 (47), s. 4-5 („Znak”-ZON); Niemcy stużą Polsce, 
and Germany, Poland opposed the idea of a peaceful Slav federation (Central European Union and the Balkan block) within the Slavonic Empire between the Baltic, the Adriatic and the Black Sea, including the Eastern nations ${ }^{161}$. Poland would base it on freedom, justice and Western Christian culture, defending small states and nations from the cult of power, western nihilism (Nazism), and eastern materialism (communism) $)^{162}$. Poland in a union with East Slavic nations could together contribute to the democratization and Christianization of Russia over time. The slogan "to melt Slavic streams in the Russian Sea" was to be replaced by the Slavic idea of equality and federalism, democracy, truth and justice. Then the difference between the Western European and the Byzantine system of collective life would be reduced, and the great idea of Slavic unity would become

161 Zagadnienie federacji środkowoeuropejskiej, cz. 1, PO, 25.04.1942, No. 1 (46), pp. 8-12; Zagadnienie Bloku Środkowo-Europejskiego, cz. 2, PO, 23.05.1942, No. 2 (47), pp. 6-10; O mocarstwowości, PO, 23.05.1942, No. 2 (47), pp. 4-5 (“Znak"-ZON); Niemcy służa Polsce, "Warta", 6.07.1941, No. 19, p. 1; Polska wigilia, "Naród", 15.12.1941, No. 25, p. 52; Przed nowa mapa Europy, "Naród", 20.01.1942, No. 2, p. 74 (Unia); Federacja Srodkowej Europy, "Reforma", 20.09.1943, No. 10, pp. 4-6; Nowy układ sit w Europie Środkowej, "Reforma", 20.11.1942, No. 2, pp. 5-6 (SP); Biuletyn Słowiański, "Prawda Dnia", luty 1943, p. 10 (Front Odrodzenia Polski); Pokój narodom dobrej woli, "Polska Zbrojna Moralnie" (PZM), 24.12.1941, No. 3, pp. 9-12 (Rycerski Zakon Krzyża i Miecza).

162 Młot czy swastyka, "Naród", 2.01.1942, No. 1, p. 43 (Unia); Nasze zasadnicze tezy ideowo-polityczne, “Znak", 10.04.1941, No. 33, pp. 3-8 (“Znak"- ZON); Rozważania programowe, "Reforma", 20.11.1942, pp. 2-3 (SP); O nowy cud nad Wisła, PZM, 20.10.1941, No. 1, pp. 10-11; Pod sztandarem Chrystusa, PZM, 24.12.1941, No. 3, p. 3 (RZKM); Polska polityka niezależna, "Prawda", maj 1942, p. 5; Misja narodu - misja Polski, "Prawda", październik 1942, p. 2 (FOP). wiedliwości i kulturze zachodniochrześcijańskiej, broniąc małe państwa i narody przed kultem siły, nihilizmem zachodnim (hitleryzm) i materializmem wschodnim $(\text { komunizm })^{162}$. Polska w unii z narodami wschodniosłowiańskimi mogłyby z czasem razem przyczynić się do demokratyzacji i chrystianizacji Rosji. Hasło „roztopienia strumyków słowiańskich w morzu rosyjskim" należało zastąpić słowiańską ideą równouprawnienia i federalizmu, demokracji, prawdy i sprawiedliwości. Wówczas zmniejszyłaby się różnica między zachodnioeuropejskim a bizantyńskim systemem organizacji życia zbiorowego i wielka idea jedności słowiańskiej stałaby się polityczną i cywilizacyjną rzeczywistością. Historyczną misją Rosji było nadanie tej jedności słowiańskiej konkretnej, materialnej siły. Misją Polski było wypełnienie tej formy politycznej nową treścią unionistyczną w miejsce dotychczasowej treści panslawistycznej i komunistycznej. Powrót Rosji do Boga i jej twórczy udział w nowej odrodzonej cywilizacji zachodnioeuropejskiej byłby ukoronowaniem posłannictwa Pol-

„Warta”, 6.07.1941, nr 19, s. 1; Polska wigilia, „Naród", 15.12.1941, nr 25, s. 52; Przed nowa mapa Europy, „Naród”, 20.01.1942, nr 2, s. 74 (Unia); Federacja Srodkowej Europy, „Reforma”, 20.09.1943, nr 10, s. 4-6; Nowy układ sił w Europie Środkowej, „Reforma”, 20.11.1942, nr 2, s. 5-6 (SP); Biuletyn Stowiański, „Prawda Dnia”, luty 1943, s. 10 (Front Odrodzenia Polski); Pokój narodom dobrej woli, „Polska Zbrojna Moralnie” (PZM), 24.12.1941, nr 3, s. 9-12 (Rycerski Zakon Krzyża i Miecza).

162 Młot czy swastyka, „Naród”, 2.01.1942, nr 1, s. 43 (Unia); Nasze zasadnicze tezy ideowo-polityczne, „Znak”, 10.04.1941, nr 33, s. 3-8 („Znak”-ZON); Rozważania programowe, „Reforma”, 20.11.1942, s. 2-3 (SP); O nowy cud nad Wisła, „PZM”, 20.10.1941, nr 1, s. 10-11; Pod sztandarem Chrystusa, PZM, 24.12.1941, nr 3, s. 3 (RZKM); Polska polityka niezależna, „Prawda”, maj 1942, s. 5; Misja narodu - misja Polski, „Prawda”, październik 1942, s. 2 (FOP). 
a political and civilized reality. Russia's historic mission was to give that unity of Slavic specific material force. The mission of Poland was to fill this form of politics with a new unionist content in place of the existing Pan-Slavic and communist content. Russia's return to God and its creative participation in the new renaissance of Western European civilization would be the crowning of Poland's mission to Eastern Slavs ${ }^{163}$. With democratic Russia, Poland was ready to enter close cooperation until the union was included, provided Poland was given the ideological leadership and separating from all influences of TuranByzantine civilization ${ }^{164}$. Poland had the right to unite the Slavs, because it was the first to oppose the armed forces of the Germans and to fight with them uncompromisingly ${ }^{165}$. It would recover together with Czechoslovakia for the Slavs (The Slav Confederation) the islands Wolin, Usedom and Rügen, Western Pomerania, Silesia, Lusatia (autonomy within Poland or the Czech Republic), East Prussia, Gdańsk. Sorbs, Pomeranians and Polabians would return to the Slavic family. The Germans would be displaced from the Slavic territories $^{166}$. In January1943, the FOP (Front

163 Biblioteka Narodowa, mf. 57308, J. Braun, Unionizm. Podstawowe zasady doktryny, pp. 12-12a (Unia); Droga Rzymu na wschód, "Prawda”, październik 1942, pp. 4-5; Romantycy, "Dodatek Prawdy", maj 1942, pp. 120-121 (FOP).

164 Fundamentalne zasady polityki zagranicznej Polski (Kazimierz Studentowicz, Polityka zagraniczna Polski), "Naród", czerwiec-lipiec 1943, No. 6-7, "Reflektor", lipiec 1943, No. 1, pp. 10-11.

165 Kropka nad i, „Warta”, 17.08.1941, No. 26, pp. 2-4 (Unia); Rewanż Słowiańszczyzny, "Prawda", styczeń 1943, pp. 4-5.

166 Zachodnia granica Polski, "Reforma", 7.02.1943, No. 4, pp. 1-3; Wracamy nad Odrę, "Refor- ski wobec Słowiańszczyzny wschodniej ${ }^{163}$. $Z$ demokratyczną Rosją Polska była gotowa wejść w ścisłą współpracę, aż do związku unijnego włącznie, pod warunkiem przyznania Polsce ideowego kierownictwa i odseparowania się od wszelkich wpływów cywilizacji turańsko-bizantyjskiej ${ }^{164}$. Polska miała prawo jednoczenia Słowian, bo jako pierwsza przeciwstawiła się zbrojnie Niemcom i prowadziła $z$ nimi bezkompromisową walkę ${ }^{165}$. Odzyskałaby dla Słowiańszczyzny razem z Czechosłowacją (Konfederacja Słowiańska) wyspy Wolin, Uznam i Rugię, Pomorze Zachodnie, Śląsk, Łużyce (autonomia w ramach Polski lub Czech), Prusy Wschodnie, Gdańsk. Do słowiańskiej rodziny wróciliby Serbołużyczanie, Pomorzanie i Połabianie. Z ziem słowiańskich zostaliby wysiedleni Niem$\mathrm{cy}^{166}$. W styczniu FOP w 1943 r. opublikował plan pokoju dla Europy Środkowej ${ }^{167}$. Pierwsza część „Bałtyk i Dunaj - Zabezpieczenie Pokoju w Europie" mówiła o ko-

163 Biblioteka Narodowa, mf. 57308, J. Braun, Unionizm. Podstawowe zasady doktryny, s. 12-12a (Unia); Droga Rzymu na wschód, „Prawda”, październik 1942, s. 4-5; Romantycy, „Dodatek Prawdy", maj 1942, s. 120-121 (FOP).

164 Fundamentalne zasady polityki zagranicznej Polski (Kazimierz Studentowicz, Polityka zagraniczna Polski), „Naród”, czerwiec-lipiec 1943, nr 6-7, „Reflektor”, lipiec 1943, nr 1, s. 10-11.

165 Kropka nad i, „Warta”, 17.08.1941, nr 26, s. 2-4 (Unia); Rewanż Słowiańszczyzny, „Prawda”, styczeń 1943, s. 4-5.

166 Zachodnia granica Polski, „Reforma”, 7.02.1943, nr 4, s. 1-3; Wracamy nad Odre, „Reforma”, 20.09.1943, nr 10, s. 6-7 (SP); Tragiczny problemat, „Naród”, 15.08.1942, s. 179; Granice, „Nakazy”, 1.07.1943, nr 19, s. 1; Kde domov můj, „Nakazy”, 8.11.1943, nr 36, s. 1 (Unia); Rzesza Niemiecka musi zniknąć, PO, 24.10.1944, nr 5, s. 10-12 (ZON).

167 Zabezpieczenie pokoju a wschodnie granice Niemiec, „Dodatek Prawdy”, styczeń 1943, s. 1-5 (FOP). 
Odrodzenia Polski - the Front of Poland's Revival) published a peace plan for Central Europe ${ }^{167}$. The first part of the "Baltic and Danube - Safeguarding of Peace in Europe" talked about the need to create a block of Baltic-Balkan states (West and Southern Slavs) headed by Poland. This would ensure the security and economic development of Central Europe from Finland to the Balkans. The second part in the works "Zaodrze"168 and "Zaodrze Wieligrodzkie, czyli Meklemburskie"169, presented a plan to restore the Germanized territories between the Oder and Nysa Lusatian and Elbe rivers to Western Slavic nations. The Zaodrze included: Wieligrodzka Land (Mecklenburg), Braniborska Land (Brandenburg), Ziemia Lubuska, Upper and Lower Lusatia. This would be historic justice for German imperialism and the Germanization of Western Slavs from the Middle Ages to the Second World War. Slavic unionism was best prepared for world unionism. Slavism was to bring new order in Europe and the world ${ }^{170}$. In

ma”, 20.09.1943, No. 10, pp. 6-7 (SP); Tragiczny problemat, "Naród", 15.08.1942, pp. 179; Granice, "Nakazy", 1.07.1943, No. 19, p. 1; Kde domov můj, "Nakazy", 8.11.1943, No. 36, p. 1 (Unia); Rzesza Niemiecka musi zniknać, PO, 24.10.1944, No. 5, pp. 10-12 (ZON).

167 Zabezpieczenie pokoju a wschodnie granice Niemiec, "Dodatek Prawdy", styczeń 1943, pp. 1-5 (FOP).

168 Ibidem, pp. 5-10.

169 Ibidem, pp. 10-12.

170 BN, mf. 57307, J. Braun, Zarys doktryny ideowej Unii, Warszawa 1943 (In 1942, Jerzy Braun organized the Central Europe Institute as a scientific institution with the status of the Delegation's agenda. It was divided into departments: political, economic, Czech-Polish, West-Slavic and Eastern. Its accomplishments came to the government. About the Slavic problems he issued in German "Wir sind Slaven”, edit. Kazimierz Kumaniecki. Stanisław Leszczycki, Kazimierz Piwarski, Henryk Batowski, nieczności utworzenia bloku państw bałtycko-bałkańskich (Słowianie Zachodni i Południowi) na czele z Polską. Zapewniłoby to bezpieczeństwo i rozwój gospodarczy Europie Środkowej od Finlandii po Bałkany. Druga część w opracowaniach „Zaodrze”168 i „Zaodrze Wieligrodzkie, czyli Meklemburskie"169 prezentowała plan przywrócenia Słowiańszczyźnie Zachodniej zgermanizowanych ziem słowiańskich między Odrą i Nysą Łużycką a Łabą. W skład Zaodrza wchodziły: Ziemia Wieligrodzka (Meklemburgia), Ziemia Braniborska (Brandenburgia), Ziemia Lubuska, Górne i Dolne Łużyce. Byłaby to sprawiedliwość dziejowa za niemiecki imperializm i germanizację Słowian Zachodnich od średniowiecza po II wojnę światową. Słowiański unionizm był najlepiej przygotowany do światowego unionizmu. Słowiańszczyzna miała przynieść nowy ład Europie i światu ${ }^{170}$. W celu zniweczenia polskiego planu jedności Słowian Zachodnich i Południowych ZSRR wykorzystał E. Beneša i marszałka Josipa-Broz Tito ${ }^{171}$.

168 Ibidem, s. 5-10.

169 Ibidem, s. 10-12.

170 BN, mf. 57307, J. Braun, Zarys doktryny ideowej Unii, Warszawa 1943 (W 1942 r. J. Braun zorganizował Instytut Europy Środkowej jako placówkę naukową o statusie agendy Delegatury. Dzielił się na wydziały: polityczny, gospodarczy, czesko-polski, zachodniosłowiański i wschodni. Jego dorobek trafiał do rządu. O sprawach słowiańskich wydawał po niemiecku pismo „Wir sind Slaven” pod redakcją Kazimierza Kumanieckiego. W pracach Instytutu uczestniczyli m.in. Stanisław Leszczycki, Kazimierz Piwarski, Henryk Batowski, Jan Dąbrowski, Kazimierz Nitsch, Tadeusz Lehr-Spławiński, Władysław Szafer, Karol Stojanowski, Jan Zachwatowicz, [w:] W. Grabowski, Polska Tajna Administracja Cywilna 1940-1945, Warszawa 2003, s. 164-165).

171 Kompleks rosyjski, „Prawda Dnia”, maj-czerwiec 1943, s. 9 (FOP); Szach-Mat, „Reforma”, 
order to undermine the Polish plan of unity of the Western and Southern Slavs, the USSR used E. Beneš and Marshal JosipBroz Tito ${ }^{171}$.

To the German and Soviet imperialism in Central Europe, the national right responded with the imperial idea (Poland of the Three Seas ${ }^{172}$, West Slavic State ${ }^{173}$, Central European Union ${ }^{174}$, Union of West

Jan Dąbrowski, Kazimierz Nitsch, Tadeusz LehrSpławiński, Władysław Szafer, Karol Stojanowski, Jan Zachwatowicz worked for the Institute, [in:] W. Grabowski, Polska Tajna Administracja Cywilna 1940-1945, Warszawa 2003, pp. 164-165).

171 Kompleks rosyjski, "Prawda Dnia", maj-czerwiec 1943, pp. 9 (FOP); Szach-Mat, „Reforma”, 25.12.1943, No. 15, pp. 4-8 (SP); Ки czemu Polska zmierza, PO, maj 1944, No. 4-5, pp. 3-4 (ZON).

172 Polska Trzech Mórz, "Walka", 19.09.1941, No. 37, pp. 2-3; Zadania Polski Trzech Mórz, "Walka”, 25.12.1942, No. 49, pp. 2-3; Ku Polsce Trzech Mórz, "Polak", 29.10.1942, No. 4, p. 7 (Stronnictwo Narodowe); O przebudowe Europy, "Myśl Polska", 15.03.1942, No. 20, pp. 346-347; M.E. Rojek, Osobowość polityczna Polski po tej wojnie, "Myśl Polska", 1.05.1942, No. 22-23, pp. 378-380 (SN w Londynie).

173 BN, mf. 54706, J. Kaliski (Karol Stojanowski), Państwo Zachodniosłowiańskie, Warszawa 1942, pp. 3-32; "Prus" (Tadeusz Maciński), U podstaw zagadnienia granicy zachodniej, "Głos", 11.06.1942, p. 10 (Narodowo-Ludowa Organizacja Wojskowa).

${ }^{174}$ AMR, DR, Departament Spraw Wewnętrznych (DSW), sygn. 202/II-22, Deklaracja ideowa grupy „Ojczyzna”, 14.12.1942, pp. 118-129; DIP, sygn. 202/III-61, J. Moszyński, Z. Wojciechowski, Stosunki polsko-niemieckie i problem Europy Środkowej, wyd. Biblioteka Wielkopolska, D.I. Druk, Warszawa 24.05 .1941$, p. 26, Sprawozdanie $z$ wydawnictw propagandowych, No. 160/43, 18.11.1943, pp. 2526; „Ojczyzna” 1939-1945, dokumenty, wspomnienia, publicystyka, red. Z. Mazur, A. Pietrowicz, Poznań 2004, pp. 359-370 (“Ojczyzna”).
Na niemiecki i radziecki imperializm w Europie Środkowej prawica narodowa odpowiedziała ideą imperialną (Polska Trzech Mórz ${ }^{172}$, Państwo Zachodniosłowiańskie ${ }^{173}$, Związek Środkowoeuropejski ${ }^{174}$, Związek Państw Zachodniosłowiańskich $^{175}$, Imperium Słowiańskie ${ }^{176}$, Związek

25.12.1943, nr 15, s. 4-8 (SP); Ku czemu Polska zmierza, PO, maj 1944, nr 4-5, s. 3-4 (ZON).

172 Polska Trzech Mórz, „Walka”, 19.09.1941, nr 37, s. 2-3; Zadania Polski Trzech Mórz, „Walka”, 25.12.1942, nr 49, s. 2-3; Ku Polsce Trzech Mórz, „Polak", 29.10.1942, nr 4, s. 7 (Stronnictwo Narodowe); O przebudowę Europy, „Myśl Polska”, 15.03.1942, nr 20, s. 346-347; M.E. Rojek, Osobowość polityczna Polski po tej wojnie „Myśl Polska”, 1.05.1942, nr 22-23, s. 378-380 (SN w Londynie).

${ }^{173}$ BN, mf. 54706, J. Kaliski (Karol Stojanowski), Państwo Zachodniosłowiańskie, Warszawa 1942, s. 3-32; „Prus” (Tadeusz Maciński), U podstaw zagadnienia granicy zachodniej, „Głos”, 11.06.1942, s. 10 (Narodowo-Ludowa Organizacja Wojskowa).

174 AAN, DR, Departament Spraw Wewnętrznych (DSW), sygn. 202/II-22, Deklaracja ideowa grupy „Ojczyzna”, 14.12.1942, s. 118-129; DIP, sygn. 202/III-61, J. Moszyński, Z. Wojciechowski, Stosunki polsko-niemieckie i problem Europy Środkowej, wyd. Biblioteka Wielkopolska, D.I. Druk, Warszawa 24.05.1941, s. 26, Sprawozdanie $z$ wydawnictw propagandowych, nr 160/43, 18.11.1943, s. 25-26; „Ojczyzna" 1939-1945, dokumenty, wspomnienia, publicystyka, red. Z. Mazur, A. Pietrowicz, Poznań 2004, s. 359-370 („Ojczyzna”).

175 AAN, DR, BP, sygn. 202/I-54, Uchwała o granicach, Ogólnopolski Zjazd Delegatów SN, Warszawa styczeń 1943, s. 313a, Uchwała o Wielkiej Polsce, s. 313a; Uchwała o Państwie Narodowym, s. 313a; Uchwała Polska w Europie, s. 314; Nasze historyczne zadania, „Wielka Polska”, 3.07.1943, s. 445; Na drodze do Wielkiej Polski, „Wielka Polska”, 13.04.1944, nr 3, s. 77; O co walczymy, „Wielka Polska, 19.08.1944, nr 20, s. 1 (Secesja SN; SN „Wielka Polska”).

176 Jaki powinien być polski imperializm?, „Miecz i Pług” (MiP), 18.08.1940, nr 17, s. 1-3; Synteza działalności politycznej Ruchu Miecz i Pług, MiP, 1.09.1943, nr 29, s. 2-5; O co wtaściwie idzie?, „Wiadomości Codzienne" (WC), 26.03.1943, nr 70, s. 2; Widmo zagłady małych narodów Europy Środkowej, WC, 23.04.1943, nr 94, s. 2; AAN, Ruch „MiP”, sygn. 208/1, Deklaracja ideowa Ruchu Miecz i Pług, 1943, s. 3-4; Program Ruchu „Miecz i Pług”, s. 5-8 („Miecz i Pług”); Czy Polska może być niepodległa, 
Slavic States ${ }^{175}$, Slavonic Empire ${ }^{176}$, West Slavic Union ${ }^{177}$, National Block of Cen-

175 AMR, DR, BP, sygn. 202/I-54, Uchwała o granicach, Ogólnopolski Zjazd Delegatów SN, Warszawa styczeń 1943, p. 313a, Uchwała o Wielkiej Polsce, p. 313a; Uchwała o Państwie Narodowym, p. 313a; Uchwała Polska w Europie, p. 314; Nasze historyczne zadania, "Wielka Polska", 3.07.1943, p. 445; Na drodze do Wielkiej Polski, "Wielka Polska”, 13.04.1944, No. 3, p. 77; O co walczymy, „Wielka Polska, 19.08.1944, No. 20, p. 1 (Secesja SN; SN "Wielka Polska").

176 Jaki powinien być polski imperializm?, "Miecz i Pług" (MiP), 18.08.1940, No. 17, pp. 1-3; Synteza działalności politycznej Ruchu Miecz i Pług, MiP, 1.09.1943, No. 29, pp. 2-5; O co właściwie idzie?, "Wiadomości Codzienne" (WC), 26.03.1943, No. 70, p. 2; Widmo zagłady małych narodów Europy Srodkowej, WC, 23.04.1943, No. 94, p. 2; AMR, Ruch MiP, sygn. 208/1, Deklaracja ideowa Ruchu Miecz i Pług, 1943, pp. 3-4; Program Ruchu „Miecz i Pług”, pp. 5-8 ("Miecz i Pług"); Czy Polska może być niepodległa, "Nowa Polska" (NP), 22.12.1941, No. 15, p. 72; Imperializm i czyn, "Do Broni", 31.03.1943, No. 4, pp. 1-3; Granice Europy Środkowej, "Biuletyn Słowiański” (BS), 8.11.1943, No. 6, pp. 3-8 (Konfederacja Narodu); A. Dudek, G. Pytel, Bolesław Piasecki. Próba biografii politycznej, Londyn 1990, p. 127; Z. Kobylańska, Konfederacja Narodu w Warszawie, Warszawa 1999, pp. 15-17, 24 (In the second half of the 1930s, a map of West Slavic powers appeared in Poland: Czech Republic, Slovakia, Hungary, Poland, Lusatia, Saxony with Dresden, Lower Silesia with Wroclaw, the northern border of Poland to the Baltic. The West Slavic Union was supposed to be a federation or a confederation, with national-cultural rights for Slavic minorities, and Jews removed to Siberia. The pro-Sanacja "Nasza Przyszłość" saw this as an ultra-Slavic provocation of Czech chauvinists, who spread it with the silent approval of the ruling circles in Prague, and inspired by the Bolsheviks to provoke Poland into a war with the Germans for lands for a thousand years not inhabited by the Slavs and to cheat the National Democracy using an anachronistic Slavic idea, [in:] Mocarstwowa brater ska unia słowacko-polsko-czesko-tuzycka, "Nasza Przyszłość", 52/1937, pp. 40-45).

177 Problem polskiej doktryny wojennej, "Naród i Wojsko" (NiW), maj 1942, No. 5, p. 5; Nic bez nas w Europie, NiW, styczeń 1943, No. 1, p. 4; Jak w madrym Rzymie, "Szaniec", 29.01.1943, No. 3, p. 79 (Organizacja Polska; "Grupa Szańca”); AMR, DR, DIP, sygn. 202/III-86, A. Rawicz (Jan Lilpop), O co walcza Narodowe Sity Zbrojne, 1943, pp. 40-41; NSZ, Od-
Zachodniosłowiański ${ }^{177}$, Narodowy Blok Państw Europy Środkowej ${ }^{178}$, Środkowoeuropejska Unia Słowiańska ${ }^{179}$, Konfede-

„Nowa Polska” (NP), 22.12.1941, nr 15, s. 72; Imperializm i czyn, „Do Broni”, 31.03.1943, nr 4, s. 1-3; Granice Europy Środkowej, „Biuletyn Słowiański” (BS), 8.11.1943, nr 6, s. 3-8 (Konfederacja Narodu); A. Dudek, G. Pytel, Bolesław Piasecki. Próba biografii politycznej, Londyn 1990, s. 127; Z. Kobylańska, Konfederacja Narodu w Warszawie, Warszawa 1999, s. 15-17, 24 (W drugiej połowie lat 30. XX w. ukazała się w Polsce mapa mocarstwa zachodniosłowiańskiego: Czechy, Słowacja, Węgry, Polska, Łużyce, Saksonia z Dreznem, Dolny Śląsk z Wrocławiem, północna granica Polski do Bałtyku. Unia Zachodniosłowiańska miała być federacją lub konfederacją, z prawami narodowo-kulturalnymi dla mniejszości słowiańskich, a Żydzi usunięci na Syberię. Prosanacyjna „Nasza Przyszłość" uznała to za ultrasłowiańską prowokację czeskich szowinistów, którą szerzą za cichą aprobatą kół rządzących w Pradze, a inspirowana przez bolszewików, żeby sprowokować Polskę do wojny z Niemcami o ziemie od tysiąca lat nie zamieszkiwane przez Słowian i złapać endecję na anachroniczną ideę słowińską, [w:] Mocarstwowa braterska unia słowacko-polsko-czesko-łużycka, ,Nasza Przyszłość", 52/1937, s. 40-45).

177 Problem polskiej doktryny wojennej, „Naród i Wojsko" (NiW), maj 1942, nr 5, s. 5; Nic bez nas $w$ Europie, NiW, styczeń 1943, nr 1, s. 4; Jak w madrym Rzymie, „Szaniec”, 29.01.1943, nr 3, s. 79 (Organizacja Polska; „Grupa „Szańca”); AAN, DR, DIP, sygn. 202/III-86, A. Rawicz (Jan Lilpop), O co walcza Narodowe Sity Zbrojne, 1943, s. 40-41; NSZ, Oddział III, sygn. 207/23, Służba Wychowawczo-Organizacyjna (SWO) NSZ, Na drodze do Wielkiej Polski, 1943, s. 1-3 (Zdaniem Polskiej Organizacji Narodowo-Syndykalistycznej, po dominacji w Europie rasy romańskiej i germańskiej nastąpiłaby po wojnie era słowiańska. W czasie wojny rodziła się Polska mocarstwowa od morza do morza, będąca ostoją i wodzem wielkiego bloku Słowian, [w:] Nowy świat rodzi się, „Biuletyn Informacyjny PONS”, 6.04.1941, nr 1, s. 2).

178 Zadania ruchu narodowego, „Aktualne Wiadomości z Polski i ze Świata” (AWŚP), 7.08.1942, nr 32, s. 1; Niebezpieczne bałamuctwa, AWPŚ, 13.11.1942, nr 46, s. 1-2 (Organizacja Wojskowa „Wilki”).

${ }^{179}$ Polska i Czechy; Rozmowy Sikorski-Beneš, „Zryw”, 15.06.1942, nr 4, s. 1-3, 6; Na święto armii, „Zryw”, 15.08.1942, nr 7, s. 1-2; Wspólny Dom, „Zryw", 1.01.1943, nr 13, s. 4-6; Rocznica paktu polsko-czeskiego, „Zryw”, 1.02.1943, nr 15, s. 6; Idea Pol$s k i$, „Zryw”, 18.03.1943, nr 18, s. 1-2 (Polska z Cze- 
tral European States ${ }^{178}$, central European Slavic Confederation ${ }^{179}$, Confederation of Slavic Nations ${ }^{180}$ ). The Polish-Czechoslovak and Yugoslav-Greek agreements of 1942 defined the natural Polish security area between the Baltic, the Adriatic and the Black Sea, antagonized the Slav

dział III, sygn. 207/23, Służba Wychowawczo-Organizacyjna (SWO) NSZ, Na drodze do Wielkiej Polski, 1943, pp. 1-3 (According to the Polish National Syndicalist Organization, after domination of the Romanesque and Germanic races in Europe, the Slavonic era would take place after the war. During the war the Polish superpower was born from the sea to the sea, being the main refuge and leader of the great Slavic block, [in:] Nowy świat rodzi sie, "Biuletyn Informacyjny PONS”, 6.04.1941, No. 1, p. 2).

178 Zadania ruchu narodowego, „Aktualne Wiadomości z Polski i ze Świata" (AWŚP), 7.08.1942, No. 32, p. 1; Niebezpieczne bałamuctwa, AWPŚ, 13.11.1942, No. 46, pp. 1-2 (Organizacja Wojskowa "Wilki")

179 Polska i Czechy; Rozmowy Sikorski-Beneš, “Zryw", 15.06.1942, No. 4, pp. 1-3, 6; Na święto armii, “Zryw", 15.08.1942, No. 7, pp. 1-2; Wspólny Dom, "Zryw", 1.01.1943, No. 13, pp. 4-6; Rocznica paktu polsko-czeskiego, "Zryw", 1.02.1943, No. 15, p. 6; Idea Polski, "Zryw", 18.03.1943, No. 18, pp. 1-2 (Polska z Czechosłowacją i Jugosławią objęłyby rolę awangardy stowiańskiego porzadku Europy, aby $w$ twardym trudzie słowiańszczyć stare płaty ziemi naszych praojców, a z twórczych elementów kultury słowiańskich narodów wytworzyć nowy piękniejszy styl życia, [in:] Na dziejowym zakręcie, "Zryw", 30.05.1942, No. 3, pp. 3-5) (Stronnictwo Zrywu Narodowego).

180 AMR, LUNS, sygn. 211/4, Statut LUNS, p. 1; Instrukcja Prac Organizacyjnych, pp. 2-4 (Legion Unii Narodów Słowiańskich - The Legion of the Union of the Slavic Nations sought to bring about the collapse of communism in the USSR, and to join the territories inhabited by the Slavs to Poland, and the Slavic Confederates would take over the Italian colonies after the war. Among the Slavic nations National Legions would be created with a common ideological basis, which would have a nationality autonomy under the LUNS The Polish Legion was the best chosen sons of the homeland. It included all the Slavs, but it initiated the selected persons loyal to the Poles. Such members from other Slavic nations would form autonomous groups, which would be branches of the Polish Legion as the center of the organization). racja Narodów Słowiańskich ${ }^{180}$ ). Umowy polsko-czechosłowacka i jugosłowiańsko-grecka z 1942 r. dzieliły naturalny polski obszar bezpieczeństwa między Bałtykiem, Adriatykiem i Morzem Czarnym, antagonizowały narody słowiańskie i były pomysłem zachodnich mocarstw ${ }^{181}$. Prawica narodowa uznała je za początek drogi do polskiego imperium, a nie degradującej znaczenie Polski federacji środkowoeuropejskiej ${ }^{182}$.Związek państw słowiańskich

chosłowacją i Jugosławią objęłyby rolę awangardy słowiańskiego porzadku Europy, aby w twardym trudzie słowiańszczyć stare płaty ziemi naszych praojców, a z twórczych elementów kultury słowiańskich narodów wytworzyć nowy piękniejszy styl życia, [w:] $\mathrm{Na}$ dziejowym zakręcie, „Zryw”, 30.05.1942, nr 3, s. 3-5) (Stronnictwo Zrywu Narodowego).

180 AAN, LUNS, sygn. 211/4, Statut LUNS, s. 1; Instrukcja Prac Organizacyjnych, s. 2-4 (Legion Unii Narodów Słowiańskich dążył do upadku komunizmu w ZSRR i przyłączenia terytoriów zamieszkałych przez ludność słowiańską do Polski. Konfederacja Narodów Słowiańskich przejęłaby po wojnie włoskie kolonie. Wśród narodów słowiańskich miały powstawać narodowe Legiony o wspólnym podłożu ideologicznym, które posiadałyby autonomię narodowościową w ramach LUNS. Legion Polski to byli wybrani najlepsi synowie ojczyzny. Obejmował wszystkich Słowian, ale wtajemniczał wybrane jednostki, które były lojalne wobec Polaków. Tacy członkowie spośród innych narodów słowiańskich tworzyli grupy na prawach autonomii, które stanowiły filie Legionu Polski, jako centralnego ośrodka organizacji).

${ }^{181}$ Zwiazek Polski i Czechosłowacji, „Myśl Polska”, 20.02.1942, nr 19, s. 328-330; Europa Srodkowa ośrodkiem pokoju, „Myśl Polska”, 20.05.1942, nr 24, s. 401-402; Związek polsko-czeski, „Walka”, 24.06.1942, nr 23, s. 1-2 (SN); Układ polsko-czeski, „Szaniec”, 31.01.1942, nr 77, s. 114; Układ polsko-czeski, „Szaniec”, 15.02.1942, nr 78, s. 114; Akt konfederacji polsko-czeskiej, „Szaniec”, 1.01.1943, nr 1, s. 1 (OP).

$182 \mathrm{Na}$ rozstajnych drogach, „Szaniec”, 22.09.1943, nr 12, s. 512-513 (Idea federacyjna była sztucznie zaktualizowanym programem wschodnim, żerującym na nastrojach słowianofilskich, prometejskich, federacyjnych, romantycznych, stanowych ziemiaństwo stanowe - mocarstwowych); Deklaracja polsko-czeska, NP, 4.02.1942, nr 19, s. 115; Sojusz 
nations and were the idea of the Western powers $^{181}$. The national right recognized it as the beginning of the path to the Polish empire, and not the Central European federation, degrading the role of Poland ${ }^{182}$. The union of the Slav countries would be its basis to which non-Slavonic states could belong. Within the empire the Slav nations would have the right to selfdetermination. Slovaks and Czechs could live together but without centralism and Czechoslovakism. Yugoslavia would be rebuilt as a federal state with equal rights for Slovenes, Croats and Serbs. Bulgaria would make a federal state with it, or union. There would be a common border between the Czech Republic and Slovakia with Yugoslavia at the expense of Austria $^{183}$. Great Poland would regain the his-

181 Zwiazek Polski i Czechosłowacji, "Myśl Polska”, 20.02.1942, No. 19, pp. 328-330; Europa Środkowa ośrodkiem pokoju, "Myśl Polska”, 20.05.1942, No. 24, pp. 401-402; Związek polsko-czeski, „Walka”, 24.06.1942, No. 23, pp. 1-2 (SN); Układ polsko-czeski, "Szaniec", 31.01.1942, No. 77, p. 114; Układ polsko-czeski, "Szaniec", 15.02.1942, No. 78, p. 114; Akt konfederacji polsko-czeskiej, "Szaniec", 1.01.1943, No. 1, p. 1 (OP).

$182 \mathrm{Na}$ rozstajnych drogach, "Szaniec", 22.09.1943, No. 12, pp. 512-513 (The federation idea was an artificially updated Eastern program, feeding on Slavophile, Promethean, Federated, Romantic, State - state gentry - superpower); Deklaracja polsko-czeska, NP, 4.02.1942, No. 19, p. 115; Sojusz Grecji z Jugosławia i konfederacja polsko-czechosłowacka, "Do Broni", 4.02.1942, No. 4, p. 5; Z emigracji i z ziem słowiańskich na emigracji, BS, październik 1942, No. 8, pp. 16-17; Konfederacja polsko-czeska, BS, listopad 1942, No. 9, p. 9; Sprawa Węier na tle zagadnień słowiańskich, BS, 31.01.1943, No. 1, pp. 2-4 (KN); Droga do wielkości wymaga wielkości, MiP, 10.05.1942, No. 13, pp. 7-8 (MiP); Konfederacja polsko-czeska, AWPŚ, 6.02.1942, No. 6, p. 4 (OW "Wilki").

183 Jak ją rozrywać niezgodami swymi chcecie, "Głos”, 13.02.1943, p. 29; “1723” (Kazimierz Próchnik), Na manowcach federacyjnych, "Głos", stanowiłby jego podstawę, do którego mogły należeć państwa niesłowiańskie. W ramach imperium narody słowiańskie miałyby prawo do samostanowienia. Słowacy i Czesi mogli wspólnie żyć, ale bez centralizmu i czechosłowakizmu. Jugosławia zostałaby odbudowana jako państwo federalne $\mathrm{z}$ równymi prawami dla Słoweńców, Chorwatów i Serbów. Bułgaria tworzyłaby $\mathrm{z}$ nią państwo federalne albo unię. Powstałaby wspólna granica Czech i Słowacji z Jugosławią kosztem Austrii ${ }^{183}$. Wielka Polska odzyskałaby historyczne ziemie, zabrane jej przez Berlin i Moskwę ${ }^{184}$. Li-

Grecji z Jugosławią i konfederacja polsko-czechosłowacka, „Do Broni”, 4.02.1942, nr 4, s. 5; Z emigracji i z ziem słowiańskich na emigracji, BS, październik 1942, nr 8, s. 16-17; Konfederacja polsko-czeska, BS, listopad 1942, nr 9, s. 9; Sprawa Wegier na tle zagadnień słowiańskich, BS, 31.01.1943, nr 1, s. 2-4 (KN); Droga do wielkości wymaga wielkości, MiP, 10.05.1942, nr 13, s. 7-8 (MiP); Konfederacja polsko-czeska, AWPŚ, 6.02.1942, nr 6, s. 4 (OW „Wilki”).

183 Jak ja rozrywać niezgodami swymi chcecie, „Głos”, 13.02.1943, s. 29; „1723” (Kazimierz Próchnik), Na manowcach federacyjnych, "Głos”, 27.02.1943, s. 31 (NLOW); AAN, NSZ, sygn. 207/5, Polska wświecie, „Biuletyn Wewnętrzny”, 22.05.1943, s. 53-54a; sygn. 207/6, Blok Środkowoeuropejski, Raport 7/73/43, 1943, s. 40; Federacja polsko-czeska podstawa ładu środkowoeuropejskiego, „Kraj”, 27.07.1943, nr 2, s. 1-2 („Ojczyzna”); Rocznica paktu polsko-czeskiego, „Zryw”, 1.02.1943, nr 15, s. 6; Jugosławia, „Zryw”, 18.03.1943, nr 18, s. 3; Idea Polski, "Zryw”, 18.03.1943, nr 18, s. 1-2 (SZN); mf. 47717, Dlaczego Wielka Jugosławia, BS, 5.04.1943, nr 3, s. 1-2; Imperium to jedność Słowian - w jedności siła, „Do Broni”, 8.12.1943, nr 12, s. 1 (KN).

184 Imperium narodu polskiego, „Walka”, 29.08.1941, nr 34, s. 2-3; Tylko wielka i silna Polska, „Walka”, 5.09.1941, nr 35, s. 1; Polska idea narodowa, „Walka”, 17.06.1942, nr 22, s. 1; Tam gdzie była Polska, „Walka”, 18.08.1943, nr 31, s. 3-6; Mały nacjonalizm i abstrakcyjny katolicyzm, „Młoda Polska”, 29.05.1943, nr 10, s. 364; Reflektorem po organizacji, „Warszawski Dziennik Narodowy”, 12.06.1943, nr 21, s. 376-377 (SN); „Prus”, U podstaw zagadnienia granicy zachodniej, „Głos”, 11.06.1942, s. 8-9; „Lar” (Zygmunt Domański), Problem granicy wschodniej, „Głos”, 9.07.1942, s. 12-14; „1723”, O 
toric lands taken by Berlin and Moscow ${ }^{184}$. Lithuania would be part of Poland ${ }^{185}$, just as Belarusians and Ukrainians, who were

27.02.1943, p. 31 (NLOW); AMR, NSZ, sygn. 207/5, Polska w świecie, "Biuletyn Wewnętrzny", 22.05.1943, pp. 53-54a; sygn. 207/6, Blok Środkowoeuropejski, Raport 7/73/43, 1943, p. 40; Federacja polsko-czeska podstawa ładu środkowoeuropejskiego, "Kraj", 27.07.1943, No. 2, pp. 1-2 (“Ojczyzna”); Rocznica paktu polsko-czeskiego, "Zryw", 1.02.1943, No. 15, p. 6; Jugosławia, "Zryw", 18.03.1943, No. 18, p. 3; Idea Polski, “Zryw”, 18.03.1943, No. 18, pp. 1-2 (SZN); mf. 47717, Dlaczego Wielka Jugosławia, BS, 5.04.1943, No. 3, pp. 1-2; Imperium to jedność Stowian - w jedności siła, "Do Broni", 8.12.1943, No. 12, p. 1 (KN).

184 Imperium narodu polskiego, "Walka", 29.08.1941, No. 34, pp. 2-3; Tylko wielka i silna Polska, "Walka", 5.09.1941, No. 35, p. 1; Polska idea narodowa, "Walka", 17.06.1942, No. 22, p. 1; Tam gdzie była Polska, "Walka", 18.08.1943, No. 31, pp. 3-6; Mały nacjonalizm i abstrakcyjny katolicyzm, "Młoda Polska", 29.05.1943, No. 10, p. 364; Reflektorem po organizacji, "Warszawski Dziennik Narodowy", 12.06.1943, No. 21, pp. 376-377 (SN); "Prus", U podstaw zagadnienia granicy zachodniej, "Głos", 11.06.1942, pp. 8-9; "Lar” (Zygmunt Domański), Problem granicy wschodniej, "Głos", 9.07.1942, pp. 12-14; "1723", O stara granicę Piastów. Przed doniosta decyzja, "Głos", 21.08.1943, pp. 56-60; "Prus", Nasze stanowisko w sprawie wschodniej granicy Polski, "Głos", 29.01.1944, pp. 77-78 (NLOW); AMR, DR, DIP, sygn. 202/III-82, Imperium Stowiańskie "Nowej Polski”, Sprawozdanie tygodniowe No. 7/42, 28 I 1942, p. 51; Wschód Polski, NP, 12.10.1943, No. 60, p. 149; Idea wielkiego pokolenia, "Do Broni”, 20.05.1942, No. 8, p. 1; Międzymorze bałtycko-czarnomorskie, "Do Broni”, 29.06.1942, No. 11, p. 5; Imperializm i czyn, "Do Broni", 31.03.1943, No. 4, pp. 1-3 (KN); K. Szajnocha (Zygmunt Wojciechowski), Szkice historyczne, (vol. 1, Warszawa 1938, 1943), [in:] „Ojczyzna” 1943-1945, pp. 411-415.

185 "Lar", Granica pótnocno-wschodnia Polski, “Głos", 12.06.1943, pp. 51-52; “Cz.", O idei jagiellońskiej i co z niej wynikło, "Głos", 18.12.1943, pp. 6371 (NLOW); Mniejszości narodowe, "Wielka Polska", 27.04.1944, No. 5, p. 78 (Secesja SN); AMR, NSZ, sygn. 207/7, Raport specjalny IV a, Litwa, 9.01.1943, pp. 2-3; Raport, C.S.W. 30 XI 1943 (Wilno, Grodno, Biatystok), pp. 41-42; Raport 108/44, Wilno 1944, p. 46; Raport Litwini, Komenda Główna NSZ, 1943, pp. 89-90; Nie damy wschodu Polski, „Narodowe Siły Zbrojne”, 30.06.1944, No. 8, p. 2; Litwę musimy właczyć do Rzeczypospolitej, NP, 4.02.1942, No. 19, p. $57(\mathrm{KN})$. twa byłaby częścią Polski ${ }^{185}$, podobnie jak Białorusini i Ukraińcy, którzy nie dorośli do posiadania państwa ${ }^{186}$. Ziemie do Odry i Nysy Łużyckiej z Rugią, Uznamem i Wolinem zajęłaby Polska, a Saksonię po

starą granicę Piastów. Przed doniosła decyzją, „Głos”, 21.08.1943, s. 56-60; „Prus”, Nasze stanowisko w sprawie wschodniej granicy Polski, „Głos”, 29.01.1944, s. 77-78 (NLOW); AAN, DR, DIP, sygn. 202/III-82, Imperium Stowiańskie „Nowej Polski”, Sprawozdanie tygodniowe nr 7/42, 28 I 1942, s. 51; Wschód Polski, NP, 12.10.1943, nr 60, s. 149; Idea wielkiego pokolenia, „Do Broni”, 20.05.1942, nr 8, s. 1; Międzymorze bałtycko-czarnomorskie, „Do Broni”, 29.06.1942, nr 11, s. 5; Imperializm i czyn, „Do Broni”, 31.03.1943, $\mathrm{nr}$ 4, s. 1-3 (KN); K. Szajnocha (Zygmunt Wojciechowski), Szkice historyczne (t. 1, Warszawa 1938, 1943), [w:] „Ojczyzna” 1943-1945, s. 411-415.

185 „Lar”, Granica pótnocno-wschodnia Polski, „Głos”, 12.06.1943, s. 51-52; „Cz., O idei jagiellońskiej i co z niej wynikło, „Głos”, 18.12.1943, s. 63-71 (NLOW); Mniejszości narodowe, „Wielka Polska”, 27.04.1944, nr 5, s. 78 (Secesja SN); AAN, NSZ, sygn. 207/7, Raport specjalny IV a, Litwa, 9.01.1943, s. 2-3; Raport, C.S.W. 30 XI 1943 (Wilno, Grodno, Bialystok), s. 41-42; Raport 108/44, Wilno 1944, s. 46; Raport Litwini, Komenda Główna NSZ, 1943, s. 8990; Nie damy wschodu Polski, „Narodowe Siły Zbrojne", 30.06.1944, nr 8, s. 2; Litwe musimy właczyć do Rzeczypospolitej, NP, 4.02.1942, nr 19, s. 57 (KN).

${ }^{186}$ Bitwy polityczne, ,Walka”, 18.11.1943, nr 44, s. 1-3; AAN, SN, sygn. 206/18, Wrzesień 1939 r., s. 100-101; M.E. Rojek, Lwów i Rzeczpospolita, „Myśl Polska", 20.02.1942, nr 19, s. 331-333 (SN); ZNO, PKH, sygn. 16320/II, K. Hrabyk, Problem rosyjski $w$ polityce endecji, s. 88-90; „Lar”, Problem granicy wschodniej, „Głos”, 9.07.1942, s. 12-14; idem, Pótnocno-wschodnia ściana, „Głos”, 6.02.1943, s. 23-24; idem, Białoruś - zapomniana i zaniedbana córa Polski, „Głos”, 29.05.1943, s. 45-47; idem, Granica pótnocno-wschodnia Polski, „Głos”, 12.06 .1943 , s. 51-53 (NLOW): Sprawa ukraińska, „Wielka Polska”, 1944, nr 11, s. 71; Ukraińcy narzędziem niemieckim, „Narodowa Agencja Prasowa”, 28.06.1944, nr 6, s. 157 (Secesja SN); Wobec zagadnienia ukraińskiego, „Placówka”, 1.01.1943, nr 1, s. 268; Ogniem i mieczem, „Praca i Walka”, 15.01.1944, nr 2, s. 9 (OP); AAN, NSZ, Oddział III, sygn. 207/23, SWO NSZ, Na drodze do Wielkiej Polski, 1943, s. 1-3; Humań czy Hadziacz?; Spichlerz ukrainski, BS, 30.06.1943, nr 5, s. 1-2, 2-5; Granice Ukrainy, BS, 6.12.1943, nr 7, s. 2-4 (KN: bez Białorusi i Ukrainy nie byłoby Imperium Słowiańskiego). 
not mature enough to have a state ${ }^{186}$. Poland would take the lands from the Oder and Lusatia to Rügen, Usedom and Wolin, and the Czech Republic would get the ones from Saxony to Chemnitz. Germans would be displaced from the Slavic lands to other side the Elbe river. The Germanized Slavic population would return to Polish culture ${ }^{187}$. A Sorbian state would be

186 Bitwy polityczne, "Walka", 18.11.1943, No. 44, pp. 1-3; AMR, SN, sygn. 206/18, Wrzesień 1939 r.,pp. 100-101; M.E. Rojek, Lwów i Rzeczpospolita, "Myśl Polska”, 20.02.1942, No. 19, pp. 331-333 (SN); ZNO, PKH, sygn. 16320/II, K. Hrabyk, Problem rosyjski w polityce endecji, pp. 88-90; "Lar", Problem granicy wschodniej, "Głos”, 9.07.1942, pp. 12-14; idem, Pótnocno-wschodnia ściana, "Głos", 6.02.1943, pp. 2324; idem, Białoruś - zapomniana i zaniedbana córa Polski, “Głos”, 29.05.1943, pp. 45-47; idem, Granica północno-wschodnia Polski, "Głos", 12.06.1943, pp. 51-53 (NLOW): Sprawa ukrainska, "Wielka Polska", 1944, No. 11, p. 71; Ukraińcy narzędziem niemieckim, "Narodowa Agencja Prasowa", 28.06.1944, No. 6, p. 157 (Secesja SN); Wobec zagadnienia ukraińskiego, "Placówka", 1.01.1943, No. 1, p. 268; Ogniem i mieczem, "Praca i Walka", 15.01.1944, No. 2, p. 9 (OP); AMR, NSZ, Oddział III, sygn. 207/23, SWO NSZ, Na drodze do Wielkiej Polski, 1943, pp. 1-3; Humań czy Hadziacz?; Spichlerz ukraiński, BS, 30.06.1943, No. 5, pp. 1-2, 2-5; Granice Ukrainy, BS, 6.12.1943, No. 7 , pp. 2-4 (KN: there would be no Slavic Empire without Belarus and Ukraine).

187 Granice Polski, "Walka”, 15.11.1940, No. 32, p. 1; Odra - Nysa Łużycka, "Walka", 26.09.1941, No. 38, pp. 2-3; Idea w poniewierce, "Młoda Polska", 20.02.1943, No. 4, p. 107; Testament Chrobrego, "Młoda Polska”, 24.04.1943, No. 8, p. 246; Straż nad Odra, "Młoda Polska", 10.05.1943, No. 9, p. 33; O przebudowę Europy, "Myśl Polska", 15.03.1942, No. 20, pp. 346-347 (SN); Pomorze, Wielkopolska, Ślask, "Biuletyn Zachodni”, sierpień 1943, No. 3, p. 10; Główny cel wojny, "Kraj”, 3.05.1944, No. 15, pp. 4-6 (“Ojczyzna”); AMR, DR, BP, sygn. 202/I-54, Uchwała o granicach, Ogólnopolski Zjazd Delegatów SN, Warszawa styczeń 1943, p. 313a; O co walczymy, "Wielka Polska", 19.08 .1944 , No. 20, p. 1 (Secesja SN); Uchwała Rady Narodowej w sprawie granic, "Szaniec", 1.01.1943, No. 1, p. 16; Nad Odrę, "Placówka”, 1.01.1943, No. 1, p. 16; AMR, Obóz Narodowy, sygn. 211/6, "Szaniec", Granice Wielkiej Polski, p. 5 (OP); NSZ, Oddział III, sygn. 207/23, SWO NSZ, Propaganda idei uderzenia na zachód, 1943, p. 8; Program terytorialny Pol-
Chemnitz Czechy. Niemcy zostaliby wysiedleni z ziem słowiańskich za Łabę. Zgermanizowana ludność słowiańska wróciłaby do polskiej kultury ${ }^{187}$. Powstałoby państwo serbołużyckie, do którego wróciliby Łużyczanie z całych Niemiec ${ }^{188}$. Prawica narodowa zaliczała Rosjan do narodów słowiańskich, ale ich państwo nie było ani słowiańskie, ani europejskie ${ }^{189}$.

187 Granice Polski, „Walka”, 15.11.1940, nr 32, s. 1; Odra - Nysa Łużycka, „Walka”, 26.09.1941, nr 38, s. 2-3; Idea w poniewierce, „Młoda Polska”, 20.02.1943, nr 4, s. 107; Testament Chrobrego, „Młoda Polska”, 24.04.1943, nr 8, s. 246; Straż nad Odra, „Młoda Polska”, 10.05.1943, nr 9, s. 33; O przebudowę Europy, „Myśl Polska”, 15.03.1942, nr 20, s. 346347 (SN); Pomorze, Wielkopolska, Śląsk, „Biuletyn Zachodni”, sierpień 1943, nr 3, s. 10; Główny cel wojny, „Kraj”, 3.05.1944, nr 15, s. 4-6 („Ojczyzna”); AAN, DR, BP, sygn. 202/I-54, Uchwała o granicach, Ogólnopolski Zjazd Delegatów SN, Warszawa styczeń 1943, s. 313a; O co walczymy, „Wielka Polska”, 19.08.1944, nr 20, s. 1 (Secesja SN); Uchwała Rady Narodowej w sprawie granic, „Szaniec”, 1.01.1943, nr 1, s. 16; Nad Odrę, „Placówka”, 1.01.1943, nr 1, s. 16; AAN, Obóz Narodowy, sygn. 211/6, „Szaniec”, Granice Wielkiej Polski, s. 5 (OP); NSZ, Oddział III, sygn. 207/23, SWO NSZ, Propaganda idei uderzenia na zachód, 1943, s. 8; Program terytorialny Polski, NP, 20.09.1941, nr 10, s. 177 (KN); Na święto armii, „Zryw”, 15.08.1942, nr 7, s. 1-2 (SZN).

188 „Prus”, Łużyce organizują się, „Głos”, 28.11.1942, s. 17; idem, Jeszcze o Łużycach, „Głos”, 6.02.1943, s. 27; „4044”, Łużyce i ich realna podstawa wyjściowa, „Głos”, 1.01.1944, s. 72-76 (NLOW); Memoriał Serbołuzyckiego Komitetu Narodowego $w$ Polsce, BS, 31.01.1943, nr 1, s. 1; Łużyce i ich stosunki $z$ Polska w okresie międzywojennym, BS, 31.01.1943, nr 1, s. 5-8 (KN).

189 T. Bielecki, Sfinks rosyjski, „Myśl Polska”, 20.02.1942, nr 19, s. 325-327 (Rosja nie jest państwem europejskim); Co to jest slawofilizm?, BS, listopad 1942, nr 9, s. 4 (BS odrzucał słowianofilstwo i panslawizm jako idee $z$ XIX w., zmierzające do zależności narodów słowiańskich od Rosji. Proponował określenie slawofilizm, którego synonimami były: idea słowiańska, idea wzajemności słowiańskiej, idea wszechsłowiańska, slawizm, słowianizm, slawofilstwo. Slawofilizm oznaczał wszelki niepanslawistyczny i niesłowianofilski przejaw sympatii do narodów słowiańskich. Slawofil to ktoś, kto lubi ze Słowianami obcować, czuje solidarność z ich interesami i dąże- 
formed, to which the Sorbs from all Germany would return ${ }^{188}$. The national right regarded the Russians the Slavic naton, but their state was neither Slavonic nor European ${ }^{189}$. The betrayers of the Slavic people E. Beneš and the Marshal J-B. Tito made Poland impossible to build a Slavic empire in Central Europe ${ }^{190}$. In the national camp, only the "Pobudka" rejected the imperial

ski, NP, 20.09.1941, No. 10, p. 177 (KN); Na święto armii, "Zryw", 15.08.1942, No. 7, pp. 1-2 (SZN).

188 "Prus", Łużyce organizuja się, "Głos", 28.11.1942, p. 17; idem, Jeszcze o Łużycach, "Głos", 6.02.1943, p. 27; “4044", Eużyce i ich realna podstawa wyjściowa, "Głos", 1.01.1944, pp. 72-76 (NLOW); Memoriał Serbołużyckiego Komitetu Narodowego $w$ Polsce, BS, 31.01.1943, No. 1, p. 1; Eużce $i$ ich stosunki z Polska w okresie międzywojennym, BS, 31.01.1943, No. 1, pp. 5-8 (KN).

189 T. Bielecki, Sfinks rosyjski, "Myśl Polska", 20.02.1942, No. 19, pp. 325-327, (Rosja nie jest państwem europejskim); Co to jest slawofilizm?, BS, listopad 1942, No. 9, p. 4 (BS rejected Slavophilism and Pantheism as ideas from the nineteenth century, aimed at the dependence of the Slav nations on Russia. It proposed the definition of Slavophilism, whose synonyms were the Slavonic idea, the idea of Slavic reciprocity, the Slavic idea, Slavism, Slavism, Slavophilia. Slavophilism meant any non-Pan-Slavistic and non-Slavophilistic gestures of kindness for the Slav nations. Slavophile is someone who likes to associate with the Slavs, feels solidarity with their interests and aspirations, wants some kind of cooperation from their people with other Slavs. Slavophilism was one of the manifestations of extended patriotism. It rejected chauvinism and xenophobia against the Slavs. Slavophiles are those who think of some kind of unifying of their own people with the Slavs in order to reconcile interests and mutual defense. The KN recognized Russians as Slavs, but not their state).

190 Sprawa słowacka; Sprawy czeskie, BS, 15.05.1943, No. 4, pp. 1-3, 8; Czechy; Słowacja, BS, 30.06.1943, No. 5, pp. 5-6; Czechy, BS, 6.12.1943, No. 7, p. 7; Czechy, BS, 24.12.1943, No. 8, pp. 6-7; Cele i elementy polityki sowieckiej, "Agencja Blok Środkowoeuropejski”, 6.04.1944, No. 1, pp. 109-110 (KN); Radzimy panu Benešowi pójść na emeryture, WC, 4.06.1943, No. 123, p. 2; Pierwszy krok pana Beneša, WC, 15.12.1943, No. 256, p. 2; Czy jest rzecza niemożliwą...?, WC, 8.01.1944, No. 5, p. 1 ("MiP").
Zdrajcy Słowiańszczyzny E. Beneš i marszałek J-B. Tito uniemożliwili Polsce budowę imperium słowiańskiego w Europie Srodkowej ${ }^{190}$. W obozie narodowym jedynie „Pobudka” odrzucała ideę imperialną. Integrację Europy Środkowej widziała na związkach unijnych ${ }^{191}$. Unia polsko-czesko-słowacko-łużycka przekształciłaby się z czasem w państwo związkowe $\mathrm{z}$ narodem słowiańskim ${ }^{192}$. Na południu powstałaby unia Jugosławii, Bułgarii i Grecji ${ }^{193}$. Polska zawiązałaby ścisłą unię z Litwą, a na arenie międzynarodowej zabiegałaby o wolność dla Białorusi i Ukrainy ${ }^{194}$. Również

niami, chciałby jakiejś współpracy swego narodu z pobratymcami. Slawofilizm stanowił jedną z postaci poszerzonego patriotyzmu. Odrzucał szowinizm i ksenofobię w stosunku do nie-Słowian. Slawofilami są ci, którzy myślą o zjednoczeniu takim lub innym własnego narodu ze Słowianami w celu uzgodnienia interesów i wzajemnej obrony. KN uznawała Rosjan za Słowian, ale nie ich państwo).

190 Sprawa słowacka; Sprawy czeskie, BS, 15.05.1943, nr 4, s. 1-3, 8; Czechy; Stowacja, BS, 30.06.1943, nr 5, s. 5-6; Czechy, BS, 6.12.1943, nr 7, s. 7; Czechy, BS, 24.12.1943, nr 8, s. 6-7; Cele i elementy polityki sowieckiej, „Agencja Blok Środkowoeuropejski”, 6.04.1944, nr 1, s. 109-110 (KN); Radzimy panu Benešowi pójść na emeryturę, WC, 4.06.1943, nr 123, s. 2; Pierwszy krok pana Beneša, WC, 15.12.1943, nr 256, s. 2; Czy jest rzecza niemożliwa...?, WC, 8.01.1944, nr 5, s. 1 („MiP”).

191 Polska a pokój; Polska a małe narody, „Pobudka", luty 1942, nr 2, s. 4-16; Polska w nowej Europie, „Głos Polski”, 7.04.1943, nr 7, s. 2 (grupa „Pobudka").

${ }^{192}$ Historia współdziałania polsko-czeskiego; Fizjografia i demografia konfederacji; Kultura polska i czeska wświetle historii; Światła i cienie konfederacji, „Pobudka”, lipiec 1942, nr 6, s. 4-15, 21-22, 26-32.

${ }^{193}$ Polska a pokój, „Pobudka”, luty 1942, nr 2, s. $4-11$.

194 Namiętności ukraińskie i białoruskie, „Pobudka”, sierpień 1942, nr 7, s. 19-22; Drogi do jedności, „Pobudka”, maj 1944, nr 1, s. 14; Ukraińcy decyduja dziś o swoim losie, „Głos Polski”, 21.09.1943, nr 17, s. 271; Ręka zawisła w powietrzu, „Słowa Prawdy”, 15.10.1943, nr 2, s. 153; Polska $i$ Wschód, „Słowa Prawdy", 7.04.1944, nr 4, s. 98-99 (Pobudka). 
idea. It saw integration of Central Europe as unions ${ }^{191}$. The Polish-Czech-Slovak-Lusatian Union would eventually transform into a union state with the Slavonic nation $^{192}$. In the south, a union of Yugoslavia, Bulgaria and Greece would be formed ${ }^{193}$. Poland would create a strict union with Lithuania, and internationally, it would seek freedom for Belarus and Ukraine ${ }^{194}$. Also, "Miecz i Pług" was in favor of the construction of Belarusian and Ukrainian states in order to renew the blood brotherhood of the great Slavic family within the Slavonic Empire. Over time, one Slavonic nation would be formed ${ }^{195}$.

Underground authorities in the occupied country did not propagate the Slavic idea because the Polish government was

191 Polska a pokój; Polska a małe narody, "Pobudka", luty 1942, No. 2, pp. 4-16; Polska w nowej Europie, "Głos Polski", 7.04.1943, No. 7, p. 2 (grupa "Pobudka").

192 Historia współdziałania polsko-czeskiego; Fizjografia i demografia konfederacji; Kultura polska i czeska $w$ świetle historii; Światta $i$ cienie konfederacji, "Pobudka”, lipiec 1942, No. 6, pp. 4-15, 21-22, 26-32. pp. 4-11.

193 Polska a pokój, "Pobudka”, luty 1942, No. 2,

194 Namiętności ukraińskie i białoruskie, "Pobudka”, sierpień 1942, No. 7, pp. 19-22; Drogi do jedności, "Pobudka", maj 1944, No. 1, p. 14; Ukraincy decyduja dziś o swoim losie, "Głos Polski", 21.09.1943, No. 17, p. 271; Ręka zawisła w powietrzu, "Słowa Prawdy", 15.10.1943, No. 2, p. 153; Polska $i$ Wschód, "Słowa Prawdy", 7.04.1944, No. 4, pp. 98-99 ("Pobudka”).

195 Skazani na wielkość, WC, 11.11.1943, No. 236, p. 1; 11 listopada, MiP, 14.11.1942, No. 19, pp. 3-5; Na drodze do niepodległości, MiP, 15.12.1943, No. 39, pp. 1-2, (Idea słowiańska i zjednoczenie Europy jest wyznaniem wiary tysięcznych rzesz członków Ruchu); AMR, Ruch “MiP”, sygn. 208/1, Deklaracja ideowa Ruchu Miecz i Pług, 1943, pp. 3-4, (The basis of the unity of Europe "will become the fraternity of the Slavic nations, joined by spirit, culture, tradition and language and their common moral mission").
„Miecz i Pług” był za budową państw białoruskiego i ukraińskiego w celu odnowienia braterstwa krwi wielkiej rodziny słowiańskiej w ramach Imperium Słowiańskiego. Z czasem miał powstać jeden naród słowiański ${ }^{195}$.

Władze podziemne w okupowanym kraju nie propagowały idei słowiańskiej, ponieważ dystansował się od niej polski rząd. Wynikało to ze słowiańskiej propagandy ZSRR, którą szerzył od 1941 r. do organizowania zbrojnego oporu pod wodzą komunistów w okupowanych przez Niemców i ich sojuszników państwach słowiańskich wbrew ich legalnym rządom. Ideę słowiańską zamierzał wykorzystać również po wojnie do uzależnienia państw słowiańskich. Natomiast niepodległościowe grupy polskich emigrantów i ugrupowania podziemne w kraju głosiły konieczność zjednoczenia pod kierunkiem Polski Słowian Zachodnich i Południowych i ewentualnie Białorusinów i Ukraińców w bloku politycznym i wojskowym w celu powstrzymania imperializmu Niemiec i ZSRR. Jedynie polska lewica niepodległościowa i rewolucyjna przedkładała ideę socjalistyczną nad słowiańską w celu integracji Europy Środkowej. W okupowanym kraju idea słowiańska jako samoistna ideowa podstawa jedności państw środkowoeuropej-

195 Skazani na wielkość, WC, 11.11.1943, nr 236, s. 1; 11 listopada, MiP, 14.11.1942, nr 19, s. 3-5; Na drodze do niepodległości, MiP, 15.12.1943, nr 39, s. 1-2 (Idea słowiańska i zjednoczenie Europy jest wyznaniem wiary tysięcznych rzesz członków Ruchu); AAN, Ruch „MiP”, sygn. 208/1, Deklaracja ideowa Ruchu Miecz i Pług, 1943, s. 3-4 (Podstawą jedności Europy „stanie się braterstwo narodów słowiańskich złączonych duchem, kulturą, tradycją i językiem oraz wspólnym ich posłannictwem moralnym"). 
distancing itself from it. This was due to the Slavic propaganda of the USSR, which it had been spreading since 1941 to organize armed resistance under the leadership of the Communists in occupied Germany and their allies in the Slavic countries against their legitimate governments. It intended to use the Slavic idea also after the war to make Slavic states dependent. On the other hand, the independence groups of Polish emigres and underground groups in Poland proclaimed the need to unite under the leadership of Poland Western and Southern Slavs and possibly Belarusians and Ukrainians in the political and military bloc in order to halt imperialism of Germany and the USSR. Only the Polish independence left and revolutionary left submitted socialist ideas to Slavic Europe in order to integrate Central Europe. In the occupied country, the Slavic idea as an ideological basis for the unity of Central European states was not as significant as the federation or the imperial one.

\section{Abstract}

After the German invasion in 1941, the USSR declared to be the defender of the Slavic nations occupied by Germany. It did not defend their allies, Czechoslovakia and Yugoslavia, against the Germans in the 1938-1941. In alliance with Germans it attacked Poland in 1939. Soviets used the Slavic idea to organize armed resistance in occupied nations. After the war, the Soviet Union intended to make them politically and militarily dependent. The Polish government rejected participation in the Soviet Slavic bloc. In the Polish political emigration and in the occupied country the Slavic idea was really popular, but as an antiSoviet idea. Poland not the Soviet Union was expected to become the head of Slavic countries in Central and South-Eastern Europe. skich nie miała takiego znaczenia jak federacyjna czy imperialna.

\section{Abstrakt}

Po niemieckiej napaści w 1941 r. ZSRR uznał się za obrońcę narodów słowiańskich okupowanych przez Niemcy. W latach 1938-1941 nie bronił swoich słowiańskich sojuszników Czechosłowacji i Jugosławii przed Niemcami. W 1939 r. w sojuszu z nimi napadł na słowiańską Polskę. Wykorzystywał ideę słowiańską do organizowania zbrojnego oporu w okupowanych narodach słowiańskich. Po wojnie zamierzał uzależnić je od siebie politycznie i militarnie. Polski rząd odrzucał udział w radzieckim bloku słowiańskim. $\mathrm{W}$ polskiej emigracji politycznej i w okupowanym kraju idea słowiańska miała znaczne poparcie, ale o charakterze antyradzieckim. Polska, a nie ZSRR, miała stać na czele państw słowiańskich w Europie Środkowej i Południowo-Wschodniej. 


\section{Bibliography / Bibliografia}

Batowski H., Polska dyplomacja na obczyźnie 1939-1941, Kraków 1991.

Duraczyński E., Rząd polski na uchodźstwie 1939-1945, Warszawa 1993.

Duraczyński E., ZSRR wobec projektów konfederacji polsko-czechosłowackiej (1940-1943), "Dzieje Najnowsze" 1997, 3.

Dzienniki Czynności Prezydenta RP Władysława Raczkiewicza 1939-1947, vol. 1 (1939-1942), edit. J. Piotrowski, Wrocław 2004.

Eberhardt P., Polski panslawizm jako idea geopolityczna, "Przegląd Geopolityczny" 2014, 7.

Europa Środkowo-Wschodnia w polskiej myśli politycznej, edit. M. Dymarski, J. Juchnowski, Wrocław 2004.

Europa unii i federacji. Idea jedności narodów i państw od średniowiecza do czasów współczesnych, edit. K. Ślusarek, Kraków 2004.

Europejskie doktryny porozumienia i wspótpracy gospodarczej w XX wieku, vol. 1, edit. K. Fiedor, Wrocław 1987.

Fertacz S., Komitet Wszechsłowiański w Moskwie 1941-1947, Katowice 1991.

Fertacz S., Polska myśl słowiańska w okresie drugiej wojny światowej, Katowice 2000.

Grabowski W., Polska Tajna Administracja Cywilna 1940-1945, Warszawa 2003.

Idea Europy i Polska w XIX i XX wieku, edit. J. Degler, Wrocław 1999.

Kamiński M.K., E. Beneš kontra generał W. Sikorski. Polityka władz czechosłowackich na emigracji wobec rządu polskiego na uchodźstwie 1939-1943, Warszawa 2005.

Kulak T., Jan Ludwik Popławski. Biografia polityczna, Wrocław 1994.

Lerski J., Emisariusz Jur, Warszawa 1989.

Marples D.R., Historia ZSRR od rewolucji do rozpadu, Wrocław 2006.

Mazur G., Biuro Informacji i Propagandy SZP-ZWZ-AK 1939-1945, Warszawa 1987.

Między przymusowa przyjaźnią a prawdziwą solidarnością Czesi - Polacy - Słowacy 1938/39-19451989, cz. 1, edit. P. Blažek, P. Jaworski, Ł. Kamiński, Warszawa 2007.

Němeček J., Edvard Beneš i Władysław Sikorski: spojrzenie ze strony czeskiej, "Dzieje Najnowsze”, $3(32) / 2000$.

„Ojczyzna” 1939-1945, dokumenty, wspomnienia, publicystyka, edit. Z. Mazur, A. Pietrowicz, Poznań 2004.

Okulewicz P., Koncepcja „Międzymorza” w myśli i praktyce politycznej obozu Józefa Piłsudskiego w latach 1918-1926, Poznań 2001.

Paruch W., Myśl polityczna obozu piłsudczykowskiego 1926-1939, Lublin 2005.

Pipes R., Rosja bolszewików, Warszawa 2005.

Polska - Kresy - Polacy. Studia historyczne, edit. S. Ciesielski, T. Kulak, K. Matwijowski, Wrocław 1994 (AUW. Historia, vol. 116, nr 1636).

Polska Partia Socjalistyczna w latach wojny i okupacji 1939-1945. Księga Wspomnień, vol. 2, edit. W. Czarnecki, Warszawa 1995.

Ponczek E., Polska myśl o pokoju w latach drugiej wojny światowej (1939-1945), Łódź 1999.

Proces integracji Polski z Unią Europejską, edit. P. Dobrowolski, M. Stolarczyk, Katowice 2001.

Przybysz K., W konspiracji. Polski ruch ludowy 1939-1945, Warszawa 2010.

Raczyński R., W sojuszniczym Londynie. Dziennik ambasadora Edwarda Raczyńskiego 1939-1945, Londyn 1960.

Raczyński E., Od Genewy do Jałty, rozmowy radiowe Edward Raczyński - Tadeusz Żenczykowski, Londyn 1988.

Rzeczpospolita Polska czasu wojny. Dziennik Ustaw i Monitor Polski 1939-1945, edit. A.K. Kunert, Warszawa 1999.

Sosnkowska J., W kręgu mitów i rzeczywistości, Warszawa 1988. 
Tyszkiewicz J., Działalność Komitetu Zachodniosłowiańskiego w latach 1939-1940, "Wrocławskie Studia z Historii Najnowszej" 1997, 4.

Wrocławskie Studia z Dziejów Najnowszych, edit. W. Wrzesiński, Wrocław 1992 (AUW. Historia vol. 90, nr 1274).

Z dziejów prób integracji europejskiej od średniowiecza do współczesności, edit. M. Pułaski, Kraków 1995.

„Ziemie Odzyskane” po drugiej wojnie światowej, edit. C. Osękowski, G. Strauchold, Zielona Góra 2015.

Žáček R., Projekt československo-polské konfederace v letech 1939-1943, Opava 2001.

Article submitted: 16.10.2016; article accepted: 14.01.2017 